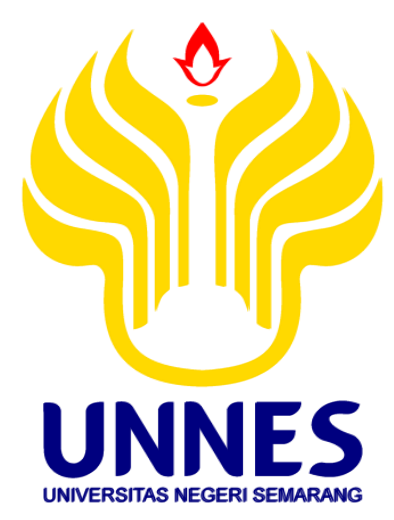

\title{
KREATIVITAS GURU DALAM PEMBELAJARAN DRUM DI SMA NEGERI 1 MOGA PEMALANG
}

\author{
SKRIPSI \\ diajukan sebagai salah satu syaratuntuk memperoleh gelar Sarjana Pendidikan \\ Program Studi Pendidikan Seni Musik
}

oleh

Diah Puspitasari

2501412065

JURUSAN PENDIDIKAN SENI DRAMA, TARI, DAN MUSIK

FAKULTAS BAHASA DAN SENI

UNIVERSITAS NEGERI SEMARANG

2017 


\section{PERSETUJUAN PEMBIMBING}

Skripsi ini telah disetujui oleh pembimbing untuk diajukan ke sidang panitia ujian skripsi.

Semarang, September 2017

Pembimbing I

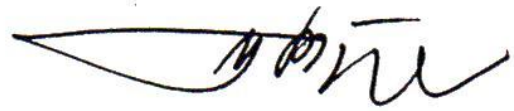

Drs Suharto, S.Pd.,M.Hum

NIP. 196510181990031002
Pembimbing II

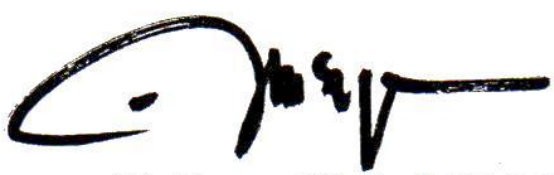

M. Usman Wafa, S.Pd.,M.Pd NIP. 198012042015041001 


\section{PENGESAHAN KELULUSAN}

Skripsi ini telah dipertahankan dihadapan sidang Panitia Ujian Skripsi Jurusan Pendidikan Seni Drama, Tari, dan Musik, Fakultas Bahasa dan Seni Universitas Negeri Semarang

Pada hari

Tanggal

M. Usman Wafa, S.Pd.,M.Pd

198012042015041001

Penguji II/Pembimbing II

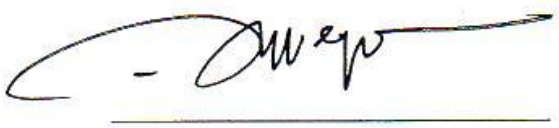

Drs. Suharto, S.Pd.,M.Pd

NIP 196510181990031002

Penguji III/Pembimbing I
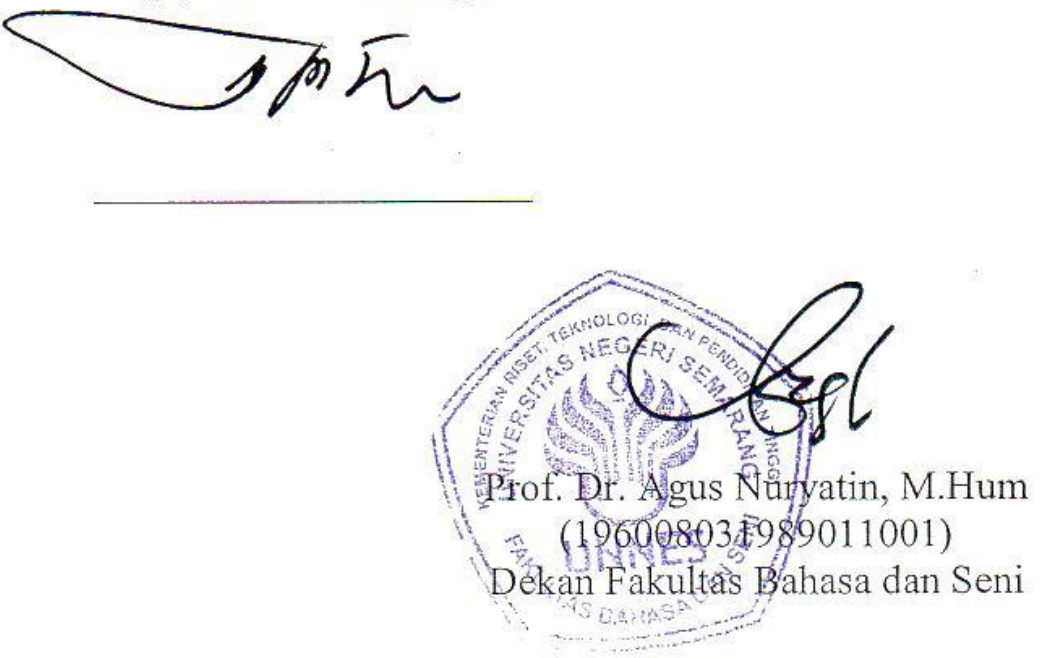


\section{LEMBAR PENGESAHAN}

Skripsi dengan judul Kreativitas Guru dalam Pembelajaran Drum di SMA

Negeri 1 Moga Pemalang ini telah disetujui oleh panitia penguji dan disahkan oleh Dekan Fakultas Bahasa dan Seni pada tanggal Oktober 2017.

Prof. Dr. M. Jazuli, M.Hum. (NIP. 196107041988031003 )

Ketua

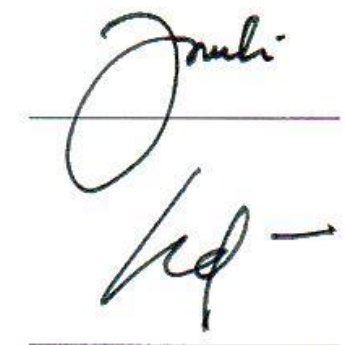

Dr. Udi Utomo, M.Si. (NIP. 196708311993011001)

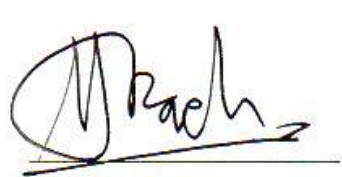

Abdul Rachman, S. Pd. M.Pd. (NIP. 198001202006041002)

Penguji 1

M.Usman Wafa, S.Pd. M.Pd (NIP. 19812042015041001)

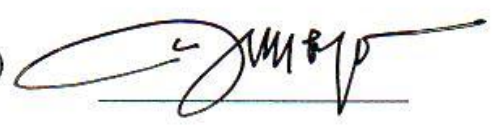

Penguji 2/Pembimbing

Drs. Suharto, S.Pd.,M.Hum. (NIP. 196510181990031002)

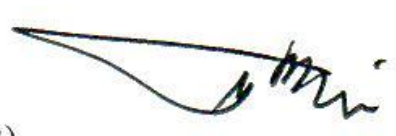

Penguji 3/Pembimbing

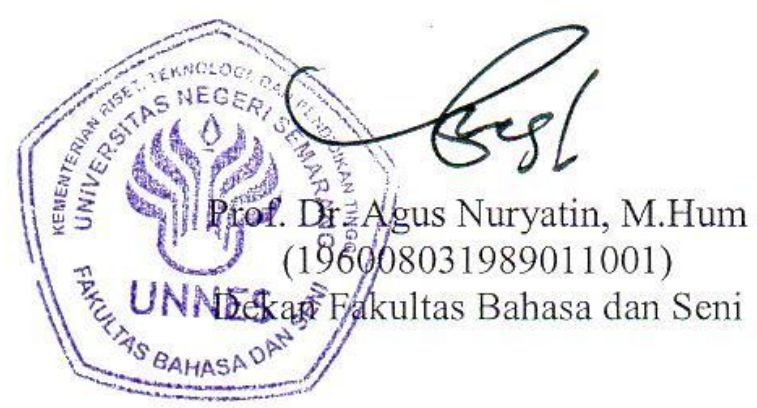




\section{PERNYATAAN}

Dengan ini saya

Nama : Diah Puspitasari

NIM $\quad: 2501412065$

Program studi $\quad$ : Pendidikan Seni Musik

Jurusan $\quad$ : Pendidikan Seni Drama, Tari, Dan Musik

Fakultas $\quad$ : Bahasa Dan Seni

Menyatakan bahwa skripsi saya yang berjudul "Kreativitas Guru dalam

Pembelajaran Drum di SMA Negeri 1 Moga Pemalang", saya tulis guna memenuhi salah satu syarat untuk memperoleh gelar sarjana pendidikan, merupakan hasil karya saya sendiri yang sebenar-benarnya setelah saya selesaikan dengan melakukan penelitian, bimbingan, diskusi dan pemaparan ujian. Semua kutipan baik yang langsung maupun tidak langsung, baik yang diperoleh dari sumber pustaka, media elektronik, wawancara langsung maupun sumber lainnya, telah disertai keterangan mengenai identitas narasumbernya dengan cara sebagai mana lazimnya dalam penulisan karya ilmiah. Jika dikemudian hari ditemukan kekeliruan dalam skripsi ini, maka saya bersedia bertanggung jawab. Demikian pernyataan ini dibuat agar digunakan sebagaimana mestinya.

Semarang, Oktober 2017

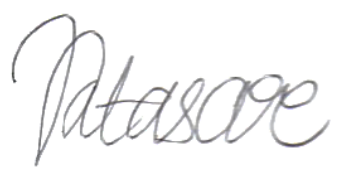

Diah Puspitasari

NIM 2501412065 


\section{MOTTO DAN PERSEMBAHAN}

\section{Motto:}

"Meneruskan kehidupan dengan baik, meskipun ada yang iri dan membenci anda".

"Awalan adalah bagian terpenting dari sebuah pekerjaan"

Mario Teguh

Persembahan :

1. Ibu Khozanah dan Bapak Arief Barbekso teristimewa atas doa, cinta, kasih sayang dan kerja kerasnya yang tanpa pamrih.

2. Kakak perempuanku Dewi Wulandari dan dan juga adik laki-lakiku Dafa Alvin Chandra Aryadhana yang selalu memberikan arahan yang bermanfaat.

3. Pacarku Denny Wahyu Nugroho yang selalu memberikan motivasi semangat yang tinggi.

4. Teman-temanku yang selalu mendorong menuju hal yang lebih baik dari masamasaku terdahulu. 
5. Sahabat-sahabat prodi Pendidikan Seni Musik yang selalu memberikan semangat dan dukungan tanpa henti. 


\section{KATA PENGANTAR}

Alhamdulillahirabil'alamin penulis panjatkan ke hadirat Allah Subhanahuwata'ala, atas rahmat, nikmat dan hidayat-Nya sehingga penulis dapat menyelesaikan skripsi yang berjudul "Kreativitas Guru dalam Pembelajaran Drum di SMA Negeri 1 Moga Pemalang" dapat terselesaikan dengan baik sebagai persyaratan untuk memperoleh gelar sarjana pendidikan.

Penulis menyadari bahwa penyusunan skripsi ini bukan hanya pemikiran dan usaha penulis semata, namun didalamnya juga terlibat berbagai pihak. Oleh karena itu pada kesempatan ini penulis menyampaikan terimakasih sedalamdalamnya kepada yang terhormat:

1. Bapak Prof. Dr. Fathur Rokhman, M. Hum., Rektor Universitas Negeri Semarang yang telah memberikan kesempatan untuk menjalankan perkuliahan di Universitas Negeri Semarang.

2. Bapak Prof. Dr. Agus Nuryatin, M. Hum., Dekan FBS Universitas Negeri Semarang yang telah memberikan ijin dan juga kemudahan administrasi dalam melaksanakan penelitian.

3. Bapak Dr. Udi Utomo, M.Si.,Ketua jurusan Sendratasik, FBS, Universitas Negeri Semarang yang telah memberikan perhatian dan arahan untuk kemudahan dan kelancaran dalam penyusunan skripsi.

4. Bapak Drs. Suharto, S.Pd, M.Hum., Dosen pembimbing I yang telah memberikan bimbingan, pengarahan serta dorongan dengan penuh kesabaran sehingga penulis dapat menyelesaikan skripsi ini. 
5. Bapak M. Usman Wafa, S.Pd, M.Pd., Dosen pembimbing II yang telah memberikan bimbingan, masukan dan motivasi kepada penulis sehingga dapat menyelesaikan skripsi ini dengan sebaik-baiknya.

6. Bapak dan Ibu dosen Jurusan Sendratasik yang telah memberikan pengetahuan dan bekal ilmu sehingga penulis mampu menyelesaikan skripsi ini.

7. Teman-teman Sendratasik angkatan 2012 yang senantiasa menemani proses pelaksanaan skripsi ini sehingga penulis dapat menyelesaikan dengan baik.

8. Seluruh pihak yang berkenan membantu penulis selama penelitian dan penyusunan skripsi ini, yang tidak bisa penulis sebutkan satu persatu.

Penulis berharap semoga skripsi ini bermanfaat bagi pengembangan ilmu pengetahuan serta menjadi bahan kajian dalam bidang ilmu yang terkait.

Semarang, Oktober 2017

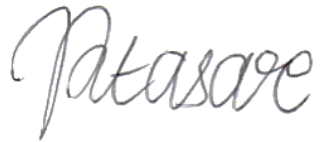

Diah Puspitasari 250142065 


\section{SARI}

Puspitasari, Diah. 2017.Kreativitas Guru dalam Pembelajaran Drum di SMA Negeri 1 Moga Pemalang”. Skripsi. Program Studi Pendidikan Seni Musik, Jurusan Seni Drama, Tari, dan Musik. Fakultas Bahasa dan Seni. Universitas Negeri Semarang. Pembimbing: Drs.Suharto, S.Pd, M.Hum, dan M. Usman Wafa, S.Pd, M.Pd.

Kata Kunci: Kreativitas, Guru, Pembelajaran, Drum.

Pembelajaran drum merupakan salah satu sub dari mata pelajaran seni budaya yang ada di kurikulum. Dalam pelaksanaan pembelajaran drum perlu adanya kreativitas. Karena latar belakang guru bukan dari akedimisi musik maka dalam pembelajaran drum guru dituntut untuk sekreatif mungkin dalam menyampaikan pembelajaran drum di SMA Negeri 1 Moga. Tujuan dari penelitian ini untuk mengetahui bagaimana kreativitas guru dalam pembelajaran drum di SMA Negeri 1 Moga.

Penelitian ini menggunakan metode penelitian kualitatif. Teknik pengumpulan data dilakukan dengan menggunakan cara observasi, wawancara, dan studi dokumen. Teknik analisis data dilakukan melalui proses pengumpulan data, merangkum data, penyajian data, dan penarikan kesimpulan.

Hasil penelitian menunjukan bahwa, kreativitas guru dalam pembelajaran drum di SMA Negeri 1 Moga cukup kreatif. guru mengajarkan cara bermain drum secara virtual dengan langkah-langkah seperti menentukan tema pembelajaran drum secara virtual, membuat pola-pola sederhana dalam pembelajaran drum secara virtual dan membuat langkah-langkah pola sederhana pembelajaran drum secara virtual. Kreativitas lain yang dimiliki guru di SMA Negeri 1 Moga yaitu, guru dapat memperkenalkan komponen-komponen alat musik drum, dengan langkah memperlihatkan secara langsung kepada siswa komponen alat musik drum dan menyebutkan fungsi komponen utama alat musk drum. Guru SMA Negeri 1 Moga juga dapat mengajarkan pola ritmis kepada siswa-siswi dengan menggunakan pola sederhana sehingga siswa dapat menirukan pola ritmis dengan mudah. Faktor pendukung yang dapat menunjang kreativitas guru dalam pembelajaran virtua drum meliputi: (1) faktor internal yakni: referensi buku, sarana dan prasarana dan keaktifan siswa; (2) faktor eksternal yakni lingkungan kebudayaan yang dapat mempengaruhi kreativitas individu. Sedangkan faktor penghambat kreativitas guru dalam pembelajaran drum meliputi: (1) keterbatasan dana; (2) keterbatasan kemampuan guru; (3) keterbatasan media pembelajaran; dan (4) kurang terawatnya fasilitas sarana dan prasarana.

Saran yang dapat diungkapkan penulis adalah bagi guru diharapkan lebih mengembangkan kreativitasnya pada materi pembelajaran yang lain, dan memperdalam pengetahuan musiknya agar materi pembelajaran lebih menarik. 


\section{DAFTAR ISI}

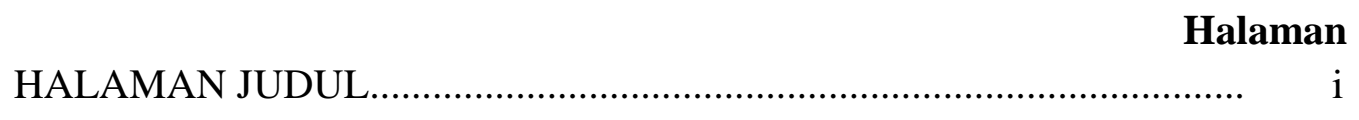

HALAMAN PENGESAHAN.......................................................... ii

HALAMAN PENGESAHAN KELULUSAN........................................ iii

LEMBAR PENGESAHAN ............................................................... iv

HALAMAN KEASLIAN SKRIPSI ...............................................

HALAMAN MOTTO DAN PERSEMBAHAN...................................... vi

HALAMAN KATA PENGANTAR .................................................... viii

HALAMAN SARI ......................................................................... $\mathrm{x}$

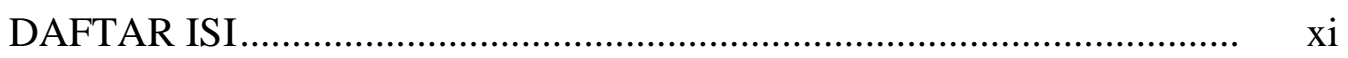

DAFTAR GAMBAR ….................................................................. $\mathrm{xV}$

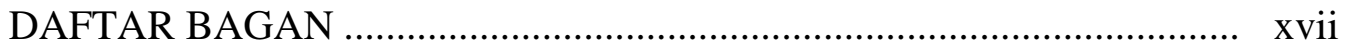

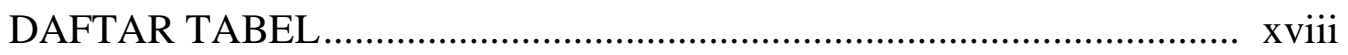

DAFTAR LAMPIRAN ..............................................................

BAB IPENDAHULUAN ................................................................

1.1 Latar Belakang .......................................................................... 1

1.2 Rumusan Masalah........................................................................ 4

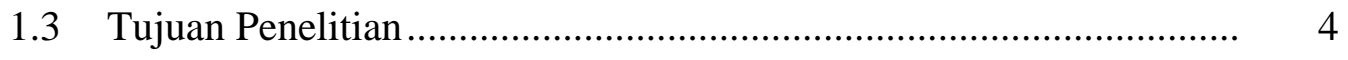

1.4 Manfaat Penelitian .................................................................... 5

1.5 Sistematika Penelitian................................................................ 5

BAB II KAJIAN PUSTAKA DAN LANDASAN TEORITIS .................. 7

$2.1 \quad$ Kajian Pustaka .............................................................................. 7 
2.2 Landasan Teori ......................................................................... 8

2.2.1 Pengertian Kreativitas............................................................. 8

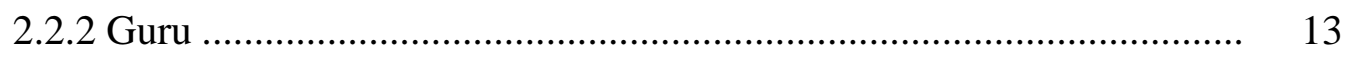

2.2.3 Pengertian Belajar ......................................................................... 16

2.2.4 Pengertian Mengajar ................................................................. 20

2.2.5 Pengertian Pembelajaran ........................................................... 22

2.2.6 Siswa (Peserta Didik) ............................................................. 25

2.2.7 Pembelajaran Seni Musik di Sekolah................................................ 25

2.2.8 Pembelajaran Apresiasi, Ekspresi, dan Kreasi Musik di Sekolah...... 30

2.2.9 Pembelajaran Drum Secara Virtual............................................... 35

2.2.9.1 Pengertian Virtual ................................................................ 35

2.2.9.2 Pengertian Alat Musik Drum ......................................................... 35

2.2.9.3 Pengertain Virtual Drum Sebagai Acuan Guru............................. 38

2.2.10 Evaluasi ......................................................................... 42

2.2.11 Kerangka Berpikir ................................................................. 43

BAB III METODE PENELITIAN ….................................................. 46

3.1Pendekatan Penelitian .................................................................. 46

3.2 Lokasi dan Sasaran Penelitian.......................................................... 46

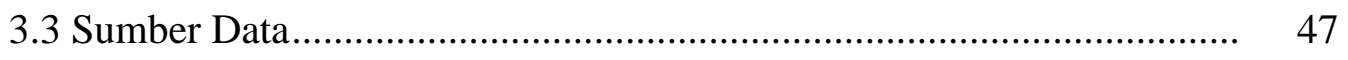

3.4 Teknik Pengumpulan Data .......................................................... 47 
3.5 Teknik Keabsahan Data ............................................................... 50

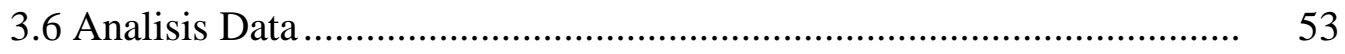

BAB IV HASIL PENELITIAN DAN PEMBAHASAN .......................... 56

4.1 Gambaran Umum Lokasi Penelitian.............................................. 56

4.1.1 Profil SMA Negeri 1 Moga .......................................................... 56

4.1.2 Visi dan Misi SMA Negeri 1 Moga ............................................... 58

4.1.3 Keadaan Sekolah................................................................... 59

4.1.4 Kegiatan Ektrakurikuler Sekolah ............................................... 62

4.1.5 Prestasi Sekolah .................................................................... 63

4.1.6 Kreativitas Guru dalam Pembelajaran Drum ................................... 63

4.1.6.1 Mengenalkan Komponen-komponen Alat Musik Drum ................ 64

1. Fungsi Komponen Alat Musik Drum …............................................ 65

4.1.6.2 Mengajarkan Cara Memainkan Alat Musik Drum Secara

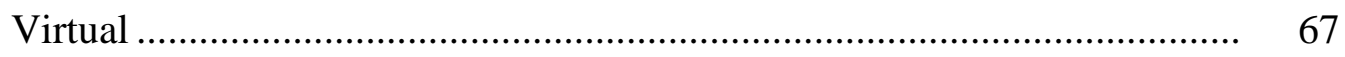

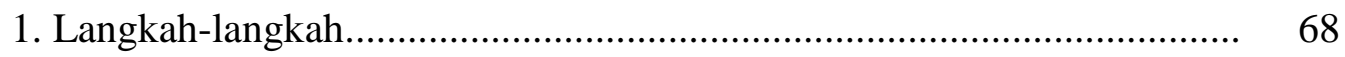

4.1.6.3 Mengajarkan Pola Ritmis Sederhana ........................................... 78

4.1.7 Faktor Pendukung dan Faktor Penghambat ................................. 80

4.1.7.1 Faktor Pendukung .................................................................. 80

4.1.7.2 Faktor Penghambat ............................................................. 84

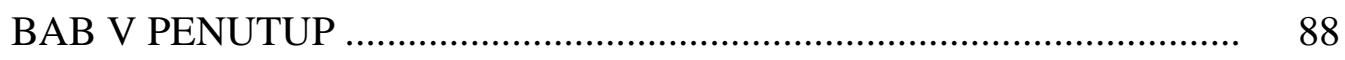

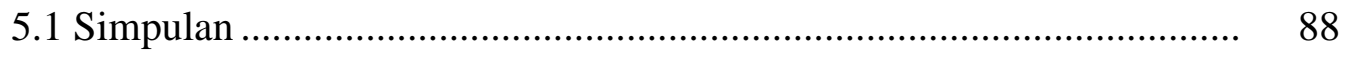

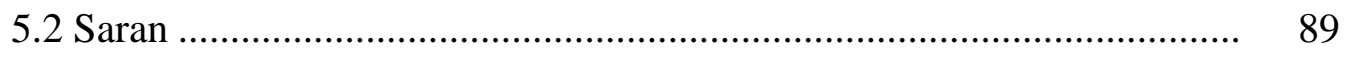

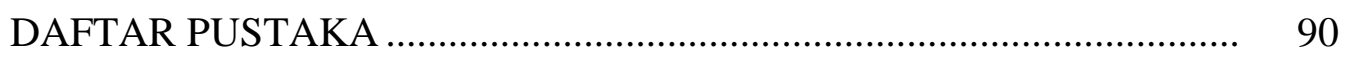




\section{DAFTAR GAMBAR}

Halaman

Gambar 4.1 Gedung SMA N 1 Moga ................................................. 57

Gambar 4.2 Ruang Laboratorium Musik SMA Negeri 1 Moga ................. 57

Gambar 4.3 Ruang Kelas SMA Negeri 1 Moga ...................................... 60

Gambar 4.4 Ekstrakurikuler Seni Musik SMA Negeri 1 Moga.................. 63

Gambar 4.5 Alat Musik Drum dan Komponennya .................................. 65

Gambar 4.6 Alat Musik Drum SMA Negeri 1 Moga ............................... 66

Gambar 4.7 Aplikasi Virtual Drum Acuan guru Sebagai Bahan Ajar........ 67

Gambar 4.8Aplikasi Virtual Drum Lesson Sebagai Acuan ........................ 68

Gambar 4.9 Siswa mempraktikkan gerakan pola satu ketukan ................. 74

Gambar 4.10Guru Mengajarkan gerakan pola 1/2 ketukan ....................... 76

Gambar 4.11Guru Mempraktikkan di Alat Musik Drum Sebenanrnya...... 77

Gambar 4.12 Siswa Mempraktikkan di Alat Musik Drum Sebenarnya ..... 77

Gambar 4.13 Guru Saat Mengajar Pola Ritmis Sederhana ....................... 78

Gambar 4.14 Pola Ritmis Sederhana yang dibuat guru ........................... 80

Gambar 4.15 Siswa Sedang Memainkan Alat Musik ............................. 81

Gambar 4.16 Siswa sedang mengikuti pembelajaran drum ...................... 83

Gambar 4.17 Peneliti bersama Guru Seni Musik SMA Negeri 1 Moga..... 109

Gambar 4.18 Peneleiti bersama Kepala Sekolah SMA Negeri 1 Moga...... 109

IGambar 4.19 Peneliti bersama Siswa....................................................... 110

Gambar 4.20 Alat Musik Drum SMA Negeri 1 Moga.............................. 110

Gambar 4.21 Siswa sedang bermain alat musik drum............................ 111 
Gambar 4.22 Guru sedang menerangkan pembelajaran virtual drum........ 111 


\section{DAFTAR BAGAN}

\section{Halaman}

2.1 Kerangka Berpikir....................................................................... 44

3.1 Skema Analisis Data Kualitatf..................................................... 55

4.22 Bagan Struktur Organisasi Sekolah SMA Negeri 1 Moga................. 61 


\section{DAFTAR TABEL}

\section{Halaman}

Tabel 1 Tindakan Pengamatan Pembelajaran Virtual Drun

Tabel 2 Daftar Nama Siswa Kelas X Bahasa............................................. 120

Tabel 3 Data Staf Pengajar dan Karyawan............................................... 121 


\section{DAFTAR LAMPIRAN}

Halaman

Lampiran 1. Instumen Penelitian .......................................................... 94

Lampiran 2. Transkrip Wawancara....................................................... 102

Lampiran 3. Surat Tugas Dosen................................................................. 107

Lampiran 4. Surat Telah Melaksanakan Penelitian .................................. 108

Lampiran 5. Dokumentasi Foto _........................................................... 109

Lampiran 6. RPP Seni Musik kelas X................................................... 112

Lampiran 7. Bagan Struktur Organisasi Sekolah SMA Negeri 1 Moga..... 119

Lampiran 8. Daftar Nama Siswa kelas X Bahasa ..................................... 120

Lampiran 9. Data Staf Pengajar dan Karyawan......................................... 121 


\section{BAB I}

\section{PENDAHULUAN}

\subsection{Latar Belakang Masalah}

Musik adalah ungkapan pernyataan isi hati manusia yang diungkapkan dalam bentuk bunyi yang teratur dengan melodi, ritme, harmoni dan timbre. Musik juga merupakan salah satu pembentuk kepribadian manusia. Karena musik itu dapat meningkatkan kreativitas, rasa estetis dan logika manusia. Pembelajaran musik lebih baik jika di mulai saat masih anak-anak. Karena dengan pembelajaran musik, tingkat kreativitas anak akan berkembang dan matang sehingga akan mempengaruhi kepribadian mereka saat dewasa. Tetapi jika tidak dikembangkan pada saat dewasa nanti kreativitas dari pengalaman-penglaman musik yang sudah ada kurang bisa berkembang dan tidak bisa mengasah ilmu tentang musik yang telah diperoleh dulu pada masa anak-anak. Kehidupan seseorang juga tidak lepas dari musik, tentunya musik yang didengar tidak lewat begitu saja dari diri individu karena musik mempunyai efek pada manusia yang dapat dihubungkan dengan segala sesuatu seperti fisik, emosional tingkah laku seseorang khususnya dalam dunia pendidikan.

Pada dasarnya tujuan pendidikan musik pada semua jenjang pendidikan sama. Pembelajaran musik di sekolah meempunyai tujuan untuk: (1) memupuk rasa seni pada tingkat tertentu dalam diri tiap anak melalui perkembangan kesadaran musik, tanggapan terhadap musik, kemampuan mengungkapkan dirinya melalui musik, sehingga memungkinkan anak mengembangkan kepekaan 
terhadap dunia sekelilingnya; (2) mengembangkan kemampuan menilai musik melalui intelektual dan artistik sesuai dengan budaya bangsanya; (3) bakal dijadikan bakal untuk melanjutkan studi kependidikan musik yang lebih tinggi (Jamalus, 1998:91).

Bermain musik pada pembelajaran Sekolah Menengah Atas merupakan suatu kegiatan rutin yang wajib digunakan seorang guru saat proses pembelajaran berlangsung khususnya pada pembelajaran seni budaya (seni musik). Guru perlu mengembangkan bentuk kreativitas musik sebanyak-banyaknya, sehingga akan membantu proses pembelajaran berjalan dengan baik, dan membuat peserta didik berhasil dalam pencapaian tujuan belajarnya.

Pembelajaran seni musik di SMA Negeri 1 Moga yang merupakan submateri dari mata pelajaran seni budaya pelajaran yang disukai oleh siswa dan menjadi pelajaran yang paling diminati (berdasarkan wawancara). Pembelajaran seni musik`cenderung dilaksanakan secara praktek dan teorinya kurang. Siswa lebih banyak melakukan kegiatan praktek bernyanyi lagu-lagu pop dan memainkan alat musik musik ritmis seperti drum, gitar, dan alat musik lainnya (yang termasuk alat musik dalam band). Sedangkan di SMA Negeri 1 Moga masih kekurangan tenaga pendidik, sehingga guru yang mengajar mata pelajaran seni musik bukanlah guru yang berlatar belakang dari pendidikan seni musik. Maka dalam hal ini, diperlukan guru yang mempunyai kreativitas yang tinggi. Sehingga pembelajaran seni musik di SMA Negeri 1 Moga disesuaikan dengan kreativitas yang dimiliki oleh guru. 
Kreativitas guru dalam pendidikan menjadi tuntutan bagi seluruh guru, apalagi guru pendidikan seni seni budaya termasuk didalamnya guru seni musik. Dalam pembelajaran seni musik di SMA Negeri 1 Moga, aktivitas berkesenian yang dilakukan harus mampu memberikan penglaman kepada siswa dalam mengembangkan konsepsi, apresiasi, dan kreasi yang dapat ditempuh melalui kegiatan mengekplorasi elemen, prinsip, proses, dan teknik berkarya dalam konteks budaya masyarakat yang beragam.

Penelitian tentang kreativitas pernah dilakukan olehHerwin Yogo Wicaksono pada tahun 2009, Fakultas Bahasa dan Seni Universitas Negeri Yogyaksarta dengan judul "Kreativitas dalam Pembelajaran Musik". Ryanto Sitofu pada tahun 2015 dari Universitas Negeri Semarang dengan judul Kreativitas Guru dalam Pembelajaran Seni Musik di TK Pertiwi 34 Kelurahan Patemon Kecamatan Gunungpati Kota Semarang. Dari peneliti tentaan yang pernah dilakukan sebelumnya membuat peneliti ingin mengertahui bagaimana kreativitas guru dalam pembelajaran drum di SMA Negeri 1 Moga, apakah hasil dari penelitian ini sama dengan hasil penelitian-penelitian sebelumnya.

Karena keterbatasan tenaga pendidik di SMA Negeri 1 Moga maka materi pembelajaran seni musik di SMA Negeri 1 Moga disesuaikan dengan kemampuan yang dimiliki oleh guru. Guru dapat memainkan alat musik drum, sehingga pada pembelajaran seni musik di SMA Negeri 1 Moga guru memilih materi pembelajaran drum. Namun guru kesulitan dalam menyampaikan materi pembelajaran drum kepada siswa sehingga guru harus memunculkan kreativitasnya dalam pembelajaran drum.Peneliti tertarik untuk meneliti 
kreativitas guru, karena guru di SMA Negeri 1 Moga yang berlatar belakang bukan dari pendidikan seni musik dapat mengembangkan kreativitas dan mengajarkan kepada para siswa dalam kegiatan pembelajaran seni musik terutama dalam pembelajaran virtual drum. Melihat latar belakang diatas, peneliti tertarik untuk melakukan penelitian tentang KREATIVITAS GURU DALAM PEMBELAJARAN DRUM DI SMA NEGERI 1 MOGA PEMALANG.

\subsection{Rumusan Masalah}

Dari latar belakang yang dikemukakan diatas maka penulis dapat menarik permasalahan sebagai berikut :

1.1.1 Bagaimana kreativitas guru dalam pembelajaran drum di SMA Negeri 1 Moga Pemalang.

1.1.2 Apa saja faktor-faktor yang mendukung dan menghambat kreativitas guru dalam pembelajaran drum di SMA Negeri 1 Moga Pemalang.

\subsection{Tujuan Penelitian}

Berdasarkan pemasalahaan yang dikemukakan di atas, tujuan dari penelitian ini adalah:

1.3.1 Mengetahui, mendeskripsikan, dan menganalisis kreativitas guru dalam pembelajaran drum di SMA Negeri 1 Moga Pemalang.

1.3.2 Mengetahui, mendeskripsikan, dan menganalisis faktor-faktor yang mendukung dan menghambat kreativitas guru dalam pembelajaran drum di SMA Negeri 1 Moga Pemalang. 


\section{4 Manfaat Penelitian}

Dalam penelitian ini terdapat dua manfaat penelitian, yaitu manfaat teoritis dan manfaat praktis:

1.4.1Manfaat teoritis penelitian ini sebagai berikut:

1.4.1.1 Menambah khasanah pengetahuan dalam bidang seni khususnya pada kreativitas guru dalam pembelajaran drum di SMA Negeri 1 Moga Pemalang.

Hasil penelitian ini dapat dijadikan sebagai referensi pada penelitian berikutnya.

\subsubsection{Manfaat praktis}

1.4.2.1 Dapat digunakan untuk wawasan, referensi dan dokumentasi bagi para pelaku seni tentang bagaimana kreativitas guru dalam pembelajaran drum di SMA Negeri 1 Moga Pemalang.

1.4.2.2 Manfaat baik mahasiswa seni musik dari penelitian ini yaitu memberikan ide untuk menganalisis lebih mendalam mengenai kreativitas guru.

\section{5 Sistematika Skripsi}

Sistematika skripsi bertujuan untuk memberikan gambaran serta mempermudah pembaca dalam mengetahui garis-garis besar dari skripsi ini, yang berisi sebagai berikut:

1.5.1 Bagian awal skripsi berisi tentang:

Judul skripsi, halaman pengesahan, halaman motto dan persembahan, kata pengantar, daftar isi, daftar lampiran, dan abstrak.

1.5.2 Bagian isi terdiri dari:

Bab 1 : Pendahuluan 
Berisi latar belakang, rumusan masalah, tujuan penelitian, manfaatpenelitian, dan sistematika penulisan skripsi.

Bab 2 : Landasan Teori

Berisi uraian tentang konsep-konsep teori analisis manajemen pertunjukan.

Bab 3 : Metode Penelitian

Berisi pendekatan penelitian, sasaran penelitian, data dan sumber data, teknik pengumpulan data, dan teknik analisis data.

Bab 4 : Hasil Penelitian

Pada bab ini memuat data-data yang diperoleh sebagai hasil penelitian dan dibahas secara deskriptif kualitatif.

Bab 5 : Penutup

Bab ini merupakan bab terakhir yang memuat kesimpulan dan saran. 


\section{BAB II}

\section{KAJIAN PUSTAKA DAN LANDASAN TEORITIS}

\subsection{Kajian Pustaka}

Penelitian tentang Kreativitas Guru dalam Pembelajaran Drum di SMA Negeri 1 Moga Pemalang belum pernah dilakukan sampai saat ini, hal tersebut yang mendorong penulis untuk melakukan penelitian tentang Kreativitas Guru dalam Pembelajaran Drum di SMA Negeri 1 Moga Pemalang, namun sudah banyak penelitian tentang Kreativitas di sekolah yang lain dan juga penelitian tentang pembelajaran drum ynag dilakukan oleh peneliti sebagai kajian penelitian.

Penelitian Wagieman Joseph tentang "Pembelajaran Musik Kreatif Pada Anak Usia Dini” pada tahun 2004 Harmonia Jurnal Pengetahuan dan Pemikiran Seni vol.5 (1), PP.601-611. Hasil dari penelitian tersebut adalah kreativitas anak dipupuk atau dikembangkan antara lain melalui pembelajaran musik. Metode yang digunakan dalam penelitian ini adalah metode deskriptif kualitatif.

Penelitian Abdul Rachman, Udi Utomo dan Hanif Iwan Saputra dengan judul penelitian tentang "Penggunaan Media Backingtrack Pada Pembelajaran Mata Kuliah Keroncong di Jurusan SENDRATASIK Universitas Negeri Semarang" pada tahun 2016 Laporan Penelitian Pusat Kajian Fakultas Bahasa dan Seni. Hasil dari penelitian ini menyatakan bahwa penggunaan media backing track pada materi memainkan pola iringan Keroncong terbagi menjadi dua yaitu backingtrack iringan engkel dan backingtrack iringan double. Metode penelitian 
yang yang digunakan adalah deskriptif dengan pendekatan musikologi dan teknologi.

Dari penelitian yang dilakukan oleh Wagieman Joseph yang berjudul tentang "Pembelajaran Musik Kreatif Pada Anak Usia Dini" yang digunakan peneliti sebagai kajian dalam penelitiannya adalah tentang teori kreativitas dan proses kreativitasnya. Sedangkan dari penelitian yang dilakukan oleh Abdul Rachman, Udi Utomo, dan Hanif Iwan Saputra yang berjudul tentang "Penggunaan Media Backingtrack Pada Pembelajaran Mata Kuliah Keroncong di Jurusan SENDRATASIK Universitas Negeri Semarang” yang digunakan peneliti sebagai kajain dalam penelitiannya adalah tentang proses kreativitas dalam penggunaan medua backingtrack.

\subsection{Landasan Teori}

\subsubsection{Pengertian Kreativitas}

Kreativitas merupakan kemampuan seseorang untuk menghasilkan pekerjaan yang baru dan tepat guna. Selain itu, kreativitas merupakan sesuatu hal yang penting baik ditinjau dari aspek individual maupun sosial, dan dapat dimunculkan dengan mempelajari karya cipta yang sudah ada sebelumnya, untuk kemudian diperbaharui sehingga menghasilkan karya cipta baru (Stenberg dalam Wicaksono, 2009:4).

Kreativitas juga merupakan kemampuan untuk melihat atau memikirkan hal-hal yang luar biasa, yang tidak lazim, memadukan informasi yang tampaknya tidak berhubungan dan mencetuskan solusi-solusi baru, yang menunjukkan kelancaran, kelenturan, dan orisinalitas dalam berpikir. Kemampuan untuk 
membuat kombinasi baru, berdasarkan data, informasi atau unsur-unsur yang ada merupakan definisi dari kreativitas. Hasil yang diciptakan tidak selalu hal-hal yang baru, tetapi juga dapat berupa gabungan (kombinasi) dari hal-hal yang sudah ada sebelumnya. Proses Pembelajaran kreativitas pada dasarnya adalah untuuk mengembangkan berbagai alternatif pemikiran atau cara dalam mengatasi berbagai permasalahan sesuai dengan apa yang ada di benaknya. proses kreatif meliputi empat tahap, yaitu (1) persiapan; (2) inkubasi; (3) iluminasi; (4) verifikasi (Munandar dalam Wicaksono, 2009:5).

Kreativitas dalam pembelajaran seni musik sangat diperlukan untuk mendapatkan pengetahuan, pemahaman, dan penguasaan yang optimal karena musik itu sendiri memiliki banyak dimensi kreatif. Dalam musik juga dapat dibedakan serta dipelajari cepat-lambat, tinggi-rendah, keras-lembut yang berguna untuk melatih kepekaan terhadap stimulli lingkungan. Selain itu, musik juga berpengaruh sebgai alat untuk meningkatkan dan membantu perkembangan kemampuan pribadi dan sosial. Ada beberapa alasan lain mengapa dibutuhkan kreativitas dalam pembelajaran musik yaitu karena aktivitas musik itu sendiri justru banyak melibatkan kegiatan yang mendorong terjadinya penciptaan yang membutuhkan kreativitas. Dengan demikian setiap anak perlu diberikan kesempatan seluas-luasnya untuk mencari pengalaman-pengalaman bermusik. Karena dengan pengalaman-pengalaman bermusik itu sendiri anak akan mengetahui bagaimana gambaran dalam bermusik sehingga pada pembelajaran seni musik lainnya anak sudah ada gambaran tentang pengalaman bermusik. Melalui musik seorang anak dapat mengambangkan imajinasi dan kreasi, 
mengkonstribusikan ekspresi diri, serta kreativitas . Selain itu musik juga dapat merangsang kreativitas dan individualitas . Hal inilah yang menjadi alasan musik disejajarkan dengan disiplin dasar lainnya dan penting untuk dihadirkan di dalam pendidikan (Djohan dalamWicaksono, 2009:5).

Dari beberapa pengertian kreativitas di atas dapat dirumuskan bahwa kreativitas adalah kemampuan yang sangat potensial yang dimiliki seseorang untuk menemukan sesuatu yang baru, baik yang orisinil maupun kombinasi dari sesuatu yang sudah ada menjadi sesuatu yang baru dan menarik.

\subsubsection{Ciri-Ciri Kreativitas}

Ciri-ciri kreativitas meliputi ciri-ciri aptitudeialah ciri-ciri yang berhubungan dengan kognisi, dengan proses berfikir. Sedangkan ciri-ciri nonaptitudeialah ciriciri yang lebih berkaitan dengan sikap atau perasaan. Kedua jenis kreativitas ini diperlukan agar perilaku kreatif dapat terwujud. Ciri-ciri kemampuan berfikir kreatif (aptitude) terdapat limasifat yaitu :pertama, berpikir lancar (fluency of thinking), adalah kemampuan untuk dapat menghasilkanbanyak gagasan atau ide. Dalamhal ini yang diperlukan kuantitas bukan kualitas. Kedua, berpikir luwes (fleksibel), yaitu kemampuan untuk memproduksigagasan, jawaban dari sudut pandang yang berbeda-beda. Ketiga, berpikir original, yaitu mampu melahirkan ungkapan yang baru, membuat kombinasi yang tidak lazim. Keempat, ketrampilan merinci (elaboration), yaitu mengembangkan suatu gagasan sehingga menjadi menarik. Kelima, ketrampilan menilai (mengevaluasi), yaitu meninjau suatu persoalan berdasarkan perspektif yang berbeda, menentukan patokan nilai tersendiri. 
Ciri-ciri afektif (non aptitude), diantaranya: Pertama, rasa ingin tahu, yaitu selalu terdorong untuk mengetahui lebih banyak, mengajukan banyak pertanyaan. Kedua, bersifat imajinatif, yaitu mampu membayangkan hal-hal yang belum pernah terjadi. Ketiga, merasa tertantang oleh kemajemukan, yaitu terdorong untuk mengatasi masalah yang sulit, tertantang oleh situasi yang rumit. Keempat, berani mengambil resiko, yakni berani memberikan jawaban meskipun belum tentu benar. Kelima, sifat menghargai, yaitu menghargai bimbingan dan pengarahan dalam hidup, menghargai kemampuan dan bakat-bakat sendiri yang sedang berkembang (Munandar dalam Sitofu, 2015 :9).

\subsubsection{Faktor-Faktor yang Mempengaruhi Kreativitas}

Faktor-faktor yang mempengaruhi kreativitas, yaitu faktor internal dan eksternal. Menurut Rogers dalam Munandar (2009:42), sebagaimana dikutip Fuad Nashori dan Rahmi Diana Mucharam, faktor internal yang mendukung berkembangnya kreativitas adalah keterbukaan seseorang terhadap pengalaman sekitarnya, kemampuan mengevaluasi hasil yang diciptakan dan kemampuan untuk menggunakanhasil yang diciptakan dan kemampuan untuk menggunakan elemen dan konsep yang telah ada. Disamping itu faktor kepribadian juga mendukung tumbuh kembangnyakreativitas seseorang, salah satunya adalah asertivitas.Ciri-cirinya adalah kepercayaan diri, kebebasan berekspresi secara jujur, tegas dan terbuka tanpa mengecilkan dan mengesampingkan orang lain dan berani bertanggung jawab. Faktor eksternal lingkungan yang mendukung berkembangnyakreativitas adalah kebudayaan yang mengandung keamanan dan kebebasan psikologis. 


\subsubsection{Komponen Kreativitas}

Ada beberapa komponen yang membangun kreativitas, dimana komponen ini merupakan unsur-unsur yang selalu terlibat dalam proses kreatifitas seseorang.

\section{Berpikir imajinatif}

Berpikir imajinatif adalah suatu proses pengembangan ide yang tidak atau belum dibatasi oleh nilai-nilai yang sudah ada. Berfikir secara imajinatif, seorang guru dapat secara bebas melakukanhal yang berimajinansi (membayangkan). Imajinasi berbeda dengan berangan-angan, karena berimajinasi memiliki tujuan untuk menciptakan atau membuat sesuatu yang tadinya tidak mungkin menjadi mungkin.

2. Keahlian

Kreativitas harus memiliki unsur keahlian, dimana tanpa keahlian, suatu ide atau gagasan bisa diwujudkan dan tidak hanya sebatas ide saja. Seorang guru tentu harus melibatkan keahlian dalam mengajarkan kepada siswa-siswi untuk bisa mewujudkan suatu ide yang kreatif dalam pembelajaran.

\section{Motivasi}

Motivasi di sini bisa motivasi yang berasal dari luar (ekstrinsik) maupun motivasi dari dalam (intrinsik). Seseorang biasanya bisa menjadi seseorang yang kreatif apabila ia didukung oleh suasana atau kondisi lingkungan yang kondusif yang bisa memberikan dukungan moril maupun materil baginya untuk menciptakan sesuatu. Seorang guru, sebelum menyusun sebuah pembelajaran, biasanya mempelajari buku-buku yang akan diajarkan untuk memperkaya ide-ide pada saat pembelajaran. Selain itu, kondisi internal seseorang juga sangat 
mempengaruhi kreativitas. Guru yang sedang dalam keadaan mood, akan mudah menghasilkan ide-ide baru untukmodel pembelajarannya, karena susasana hatinya mendukung. Sebaliknya, jika tidak, makaguru akan sulit untuk mengembangkan ide-ide yang akan disampaikan (Munandar, 1985:64).

\subsubsection{Guru (Tenaga Kependidikan)}

\subsubsection{Pengertian Guru (Tenaga Kependidikan)}

Guru adalah tenaga pendidik yang memberikan sejumlah ilmu pengetahuan kepada anak didik di sekolah (Saiful Bahri dalam Fathurrohman, 2007:43). Selain memberikan sejumlah ilmu pengetahuan, guru juga bertugas menanamkan nilainilai dan sikap kepada anak didik agar anak didik memiliki kepribadian yang paripurna. Dengan keimuan yang dimilikinya, guru membimbing anak didik dalam mengembangkan potensinya.

Menurut Muhaimin dan Abdul Mujib (dalam Fathurrohman, 2007:44), guru adalah orang dewasa yang bertanggungjawab memberi pertolongan pada anak didik dalam perkembangan jasmani dan rohaninya, agar mencapai tingkaat kedewasaan, mampu berdiri sendiri dan memenuhi tingkat kedewasaannya, mampu berdidi sendiri memenuhi tugasnya sebagai hamba dan khalifah Allah SWT dan mampu sebagai makhluk sosial dan sebagai makhluk hidup yang mandiri.

Menurut Hamalik (2013:117) jabatan guru dikenal sebagai suatu pekerjaan profesional, artinya jabatan ini memerlukan suatu keahlian khusus. Latar belakang pendidikan dan pengalaman mengajar akan mempengaruhi kompetensi guru dalam mengajar. Guru pemula dengan latar belakang pendidikan, akan lebih 
mudah dalam menyesuaikan diri dalam lingkungan sekolah. Guru yang bukan berlatarbelakang dari pendidikan keguruan akan banayk menemukan masalah di dalam kelas. Kepribadian guru juga sangat berpengaruh terhadap keberhasilan belajar mengajar. Dalam melaksanakan tugasnya mengantarkan anak didk menjadi orang yang berilmu pengetahuan dan kepribadian yang baik sehingga bisa dicontoh oleh siswanya (Fathurrohman, 2007:44).

Performance guru dalam mengajar di pengaruhi berbagai faktor, seperti tipe kepribadian, latar belakang pendidikan, pengalaman dan yang tak kalah penting adalah pandangan filosofis guru kepada murid. Guru yang memandang anak didik sebagai makhluk individual yang tidak memiliki kemampuan akan menggunakan pendekatan metode teacher centered, sebab murid dipandangnya sebagai gelas kososng yang bisa diisi apapun. Padahal tugas guru adalah membimbing, mengarahkan, dan memotivasi anak didik dalam mengembangkan potensinya (Fathurrohman dalam Fathurrohman, 2007:43).

Disamping itu, guru juga dituntut menguasai berbagai kompetensi (kecakapan) dalam melaksanakan profesi keguruannya agar dapat menciptakan lingkungan belajar yang baik bagi seperti didik, sehingga tujuan pengajaran dapat tercapai dengan optimal. Hal ini menunjukkan betapa pentingnya peran seorang guru dalam menentukan keberhasilan belajar mengajar.

Dari keterangan di atas, dapat disimpulkan bahwa guru adalah tenaga pendidikan yang memberikan sejumlah ilmu pengetahauan kepada anak didiknya, selain menajdi fasilitator guru juga bertugas membimbing, mengarahkan, dan 
memotivasi anak didik dalam mengembangkan potensinya, sehingga tujuan dari pembelajaran dapat tercapai dengan optimal.

\subsubsection{Peranan Guru}

Mengajar itu adalah mendidik, namun masih ada orang yang berpandangan bahwa peranan guru hanya mendidik dan mengajar saja. Dan mereka sudah mengalami kekeliruan besar bahwa tugas itu hanya satu-satu bagi setiap guru.

Pandangan modern seperti yang dikemukakan oleh Adams dan Dickey (dalam Hamalik,2013:123), berpendapat bahwa peran guru sesungguhnya sangat luas yaitu meliputi: (1) guru sebagai pengajar (teacher as instructor); (2) guru sebagai pembimbing (teacher as counsellor); (3) guru sebagai ilmuan (teacher as scientist); dan (4) guru sebagai pribadi (teacher as person).

Sekolah berfungsi sebagai penghubung antara ilmu dan teknologi dengan masyarakat, di mana sekolah merupakan lembaga yang turut mengemban tugas memodernisasi masyarakat dan di mana sekolah turut serta secara aktif dalam pembengunan. Maka dengan demikian peranan guru menjadi lebih luas (Hamalik, 2013:123-126), meliputi juga: (1) guru sebagai penghubung (tacher as communicator); (2) guru sebagai modernisator; dan (3) guru sebagai pembangun (teacher as contructor). Peranan-peranan tersebut jika dijabarkan satu per satu adalah sebagai berikut: (1) guru sebagai pengajar; (2) guru sebagai pembimbing; (3) guru sebagai pemimpin; (4) guru sebagai ilmuan; (5) guru sebagai pribadi; (6) guru sebagai penghubung; (7) guru sebagai pembaharuan; dan (8) guru sebagai pembangunan. 


\subsubsection{Tanggung jawab Guru}

Berdasarkan peranan profesional guru modern maka sudah tentu menimbulkan atau menambah tanggung jawab guru menjadi lebih besar. Tanggung jawab itu adalah sebagai berikut: (1) guru harus menuntut muridmuridnya belajar; (2) turut serta membina kurikulum sekolah; (3) melakukan pembinaan terhadap diri siswa (kepribadian, watak, dan jasmaniah); (4) memberikan bimbingan kepada murid; (5) melakukan diagnosis atas kesulitankesulitan belajar dan mengadakan penilaian atas kemajuan belajar; (6) menyelenggarakan penelitian; (7) mengenal masyarakat dan ikut serta aktif; (8) menghayati, mengamalkan, dan mengamankan Pancasila; (9) turut serta menbantu terciptanya kesatuan dan persatuan bangsa dan perdamaian dunia; (10) turut menyukseskan pembangunan; (11) tanggung jawab meningkatkan peranan profesional guru (Hamalik, 2013:127).

\subsubsection{Pengertian Belajar}

Belajar adalah modifikasi atau memperteguh kelakuan melalui pengalaman (learning is defined as the modification or strengthening of behavior throught experiencing). Menurut pengertian ini, belajar adalah merupakan suatu proses, suatu kegiatan dan bukan suatu hasil atau tujuan. Belajar bukan hanya mengingat, akan tetapi lebih luas daripada itu, yakni mengalami. Hasil belajar bukan suatu penguasaan hasil latihan, melainkan perubahan kelakuan (Hamalik, 2013:36). Pengertian ini sangat berbeda dengan pengertian lama tentang belajar, yang menyatakan bahwa belajar adalah memperoleh pengetahuan, bahwa belajar adalah latihan-latihan pembentukan kebiasaan secara otomatis dan seterusnya. 
Belajar menurut pandangan Skinner adalah suatu perilaku. Pada saat orang belajar, maka responsnya menjadi lebih baik. Sebaliknya, bila ia tidak belajar maka responsnya menurun. Dalam belajar ditemukan adanya hal seperti: (1) kesempatan terjadinya peristiwa yang menimbulkan respons pembelajar: (2) respons si pembelajar; (3) konsekuensi yang bersifat menguatkan respons tersebut. Pemerkuat terjadi pada stimulus yang menguatkan konsekuensi tersebut. Sebagai ilustrasi, perilaku respons si pembelajar yang baik diberi hadiah. Sebaliknya, perilaku respons yang tidak baik diberi teguran dan hukuman (Dimyati, 2006:9).

Menurut Gagne (dalam Dimyati, 2006:10) belajar merupakan kegiatan yang kompleks. Hasil belajar berupa kapabilitas. Setelah belajar orang memiliki keterampilan, pengetahuan, sikap, dan nilai. Timbulnya kapabilitas tersebut adalah dari: (1) stimulasi yang berasal dari lingkungan, dan (2) proses kognitif yang dilakukan oleh pembelajar. Dengan demikian, belajar adalah seperangkat proses kognitif yang mengubah sifat stimulasi lingkungan, melewati pengolahan informasi, menjadi kapabilitas baru.

Menurut Hilgard dan Bower (dalam Fathurrohman, 2007:5-6) didalam bukunya Theoris of Learning (1975) mengatakan bahwa belajar berhubungan dengan perubahan tingkah laku seseorang terhadap situasi tertentu yang disebabkan oleh pengalaman yang berulang-ulang dalam situasi itu, dimana perubahan tingkah laku itu tidak dapat dijelaskan ataudasar kecendurungan respon pembawaan, kematangan atau keadaan-keadaan sesaat sseorang (misalnya kelelahan, pengaruh obat dan sebagainya). 
Belajar pada hakikatnya adalah " perubahan” yang terjadi di dalam diri seseorang setelah melakukanaktifitas tertentu. Walaupun pada kenyataannya tidak semua perubahan termasuk kategori belajar. Misalnya perubahan fisik, mabuk, gila, dan sebagainya. Dalam belajar yang terpenting adalah proses bukan hasil yang diperolehna. Artinya, belajar harus diperoleh dengan usaha sendiri, adapun orang lain itu hanya sebagai perantara atau penunjang dalam kegiatan belajar agar belajar itu dapat berhasil dengan baik (Fathurrohman, 2007:6).

Dari beberapa pendapat dan definisi diatas dapat disimpulkan bahwa belajar merupakan suatu proses yang dilakukan seseorang untuk memperoleh perubahan yang baru bagi tingkah lakunya sebagai hasil dari pengalamannya sendiri dengan berbagai interaksi dengan lingkungannya.

\subsubsection{Prinsip-prinsip Belajar}

William Burton dalam (Hamalik, 2013:31-32) menyimpulkan uraiannya teantang prinsip-prinsip belajar sebagai berikut :

1. Proses belajar ialah pengalaman, berbuat, mereaksi, dan melampaui (under going).

2. Proses itu melalui bermacam-macam ragam pengalaman dan mata pelajaranmata pelajaran yang terpusat pada suatu tujuan tertentu.

3. Pengalaman belajar secara maksimum bermakna bagi kehidupan siswa.

4. Pengalaman belajar bersumber dari kebutuhan dan tujuan siswa sendiri yang mendorong motivasi dan kontinu.

5. Proses belajar dan hasil belajar disyarati oleh hereditas dan lingkungan. 
6. Proses belajar dan hasil usaha belajar secara materiil dipengaruhi oleh perbedaan-perbedaan individual di kalangan murid-murid.

7. Proses belajar berlangsung secara efektif apabila pengalaman-pengalaman dan hasil-hasil yang diinginkan disesuaikan dengan kematangan siswa.

8. Proses belajar yang terbaik apabila siswa mengetahui status dan kemajuan.

9. Proses belajar merupakan kesatuan fungsional dari berbagai prosedur.

10. Hasil-hasil belajar secara fungsional bertalian satu sama lain, tetapi dapat didiskusikan secara terpisah.

11. Proses belajar berlangsung secara efektif di bawah bimbingan yang merangsang dan membimbing tanpa tekanan dan paksaan.

12. Hasil-hasil belajar adalah pola-pola perbuatan, nilai-nilai, pengertianpengertian, sikap-sikap, apresiasi, abilitas, dan keterampilan.

13. Hasil-hasil belajar diterima oleh siswa apabila mendapat kepuasan pada kebutuhannya dan berguna serta bermakna baginya.

14. Hasil-hasil belajar dilengkapi dengan jalan serangkaian pengalamanpengalaman yang dapat dipersamakan dan dengan pertimbangan yang baik.

15. Hasil-hasil belajar itu lambat laun dipersatukan menjadi kepribadian dengan kecepatan yang berbeda-beda.

16. Hasil-hasil belajar yang telah dicapai adalah bersifat kompleks dan dapat berubah-ubah (adaptable), jadi tidak sederhana dan statis.

\subsubsection{Faktor-faktor Belajar}

Prinsip-prinsip belajar yang hanya memberikan petunjuk umum tentng belajar. Tetapi prinsip-prinsip itu tidak dapat dijadikan hukum belajar yang 
bersifat mutlak, kalau tujuan belajar berbeda maka dengan sendirinya acara belajar juga harus berbeda. Karena belajar yang efektif sangat dipengaruhi oleh faktor-faktor kondisional yang ada seperti: (1) faktor kegiatan; (2) belajar memerluka latihan, dengan jalan: relearning, recalling, dan reviewing; (3) belajar siswa lebih berhasil; (4) siswa yang belajar perlu mengetahui apakah siswa berhasil atau gagal dalam belajarnya; (5) faktor asosiasi besar manfaatnya dalam belajar; (6) pengalaman masa lampau (bahan apersepsi) dan pengertian-pengertian yang telah dimiliki oleh siswa; (7) faktor kesiapan belajar; (8) faktor minat dan usaha; (9) faktor-faktor fisiologis; dan (10) faktor intelegensi (Hamalik, 2013:32$33)$.

\subsubsection{Pengertian Mengajar}

Mengajar menurut Muhammad Ali (dalam Fathurrohman, 2008:7), merupakan suatu proses yang komples. Tidak hanya sekedar menyampaikan informasi dari guru kepada siswa. Banyak kegiatan maupun tindakan yang harus dilakukan, terutama bila hasil belajar yang diinginkan lebih baik pada seluruh siswa. Dalam arti, membutuhkan rumusan yang dapat meliputi seluruh kegiatan dan tindakan dalam perbuatan mengajar itu sendiri.

Mengajar merupakan suatu perbuatan yang kompleks. Perbuatan mengajar yang kompleks dapat diterjemahkan sebagai penggunaan secara integratif sejumlah komponen yang terkandung dalam perbuatan mengajar itu untuk menyampaikan pengajaran (Mutakhir dalam Fathurrohman, 2007:8).

Hamalik (dalam Fathurrohman, 2007:7) mendefinisikan mengajar sebagai proses menyampaikan pengetahuan dan kecakapan kepada siswa. Mengajar juga 
adalah suatu aktivitas profesional yang memerlukan keterampilan tingkat tinggi dan menyangkut pengambilan keputusan (Davies dalam Fathurrohman, 2007:7).

Dalam mengajar, kedudukan guru sudah tidak dapat lagi dipandang sebagai penguasa tunggal dalam kelas atau sekolah, tetapi dianggap sebagai Manager $O f$ Learning (pengelola belajar) yang perlu senantiasa siap membimbing dan membantu para siswa dalam menempuuh perjalanan menuju kedewasaan mereka sendirri yang utuh dan menyeluruh (Fathurrohman, 2007: 8).

Hamalik (2013:44-53) membahas pengertian mengajar yang bersumber dari 4 pendapat yang dipandang sebagai pendapat yang lebih menonjol

1. Mengajar adalah menyampaikan penyampiakn pengatahuan kepada siswa didik atau murid di sekolah. Teori pendidikan yang bersikap pada mata pelajaran yang disebut formal atau tradisional. Implikasi dari pengertian tersebut anatara lain seperti: (a) pengajaran dipandang sebagai persiapan hidup; (b) pengajaran adalah suatu proses penyampain; (c) penguasaan pengetahuan dalah tujuan utama; (d) guru dianggap yang paling berkuasa; (e) murid selalu bertindak sebagai penerima; dan (f) pengajaran hanya berlangsung di ruangan kelas.

2. Mengajar adalah mewariskan kebudayaan kepada generasi muda melalui lembaga pendidikan sekolah. Implikasi dari rumusan ini adalah sebagai berikut: (a) pendidikan bertujuan membentuk manusia berbudaya; (b) pengajaran berarti suatu proses pewarisan; (c) bahan pengajaran bersumber dari kebudayaan; dan (d) siswa adalah generasi muda sebagai ahli waris.

3. Mengajar adalah usaha mengorganisasi lingkungan sehinggamenciptkan kondisi belajar bagi siswa. Implikasi dari rumusan tersebut adalah sebagai 
berikut: (a) pendidikan bertujuan mengembangkan atau mengubah tingkah laku siswa; (b) kegiatan pengajaran adalah dalam mengorganisasi lingkungan; dan

(c) siswa dipandang sebagai suatu organisme yang hidup.

Dengan kata lain, mengajar adalah penciptaan sistem lingkungan yang memungkinkan terjadinya proses belajar. Sistem lingkungan itu terdiri dari komponen-komponen yang saling mempengaruhi, yakni tujuan instruksional yang ingin dicapai, materi yang diajarkan, guru dan siswa yang memainkan peranan serta ada dalam hubungna sosial tertentu, jens kegiatan yang dilakukan, serta sarana dan prasarana belajar mengajar yang tersedia.

\subsubsection{Pengertian Pembelajaran}

Pembelajaran adalah interaksi guru dan siswa yang melakukan proses belajar yang didalamnya terdapat kegiatan operasi formal, prediksi, eksperimentasi, dan eksplanasi serta membelajarkan siswa dalam belajar bagaimana belajar memperoleh dan memproses pengetahuan, ketrampilan, dan sikap (Dimyati, 2006:38).

Menurut Hamalik (2013:57) Pembelajaran adalah suatu kombinasi yang tersusun meliputi unsur-unsur manusiawi, material, fasilitas, perlengkapan, dan prosedur yang saling mempengaeruhi mencapai tujuan pembelajaran. Manusia terlibat dalam sistem pengajaran terdiri dari siswa, guru, dan tenaga lainnya, misalnya tenaga laboratorium. Material meliputi buku-buku, papan tulis, dan kapur, fotografi, slide dan film, audio dan video tape. Fasilitas dan perlengkapan terdiri dari ruangan kelas, perlengkapan audio visual, juga komputer. Prosedur, 
meliputi jadwal dan metode penyampaian informasi, praktik, belajar, ujian, dan sebagainya.

Menurut Darsono dkk. (2000:24) pembelajaran bisa dibedakan menjadi dua yaitu pembelajaran secara umum dan pembelajaran secara khusus. Pengertian pembelajaran secara umum adalah suatu kegiatan yang dilakukan oleh guru sedemikian rupa, sehingga tingkah laku siswa berubah ke arah yang lebih baik.

Pengertian pembelajaran secara khusus menurut Darsono dkk. (2000:2425) dapat dilihat dari beberapa aliran psikologis seperti dibawah ini:

1. Aliran Behavioristik

Pembelajaran adalah usaha guru membentuk tingkah laku yang diinginkan dengan menyediakan lingkungan (stimulus). Agar terjadi hubungan stimulus dengan respon (tingkah laku yang diinginkan) perlu latihan, dan setiap latihan yang berhasil perlu diberi hadiah atau reinforcement (penguatan).

\section{Aliran Kognitif}

Pembelajaran adalah cara guru memberikan kesempatan kepada siswa untuk berpikir agar dapat mengenal dan memahami apa yang sedang dipelajari. Ini sesuai dengan aliran belajar kognitif yang menekankan pada kemampuan kognisi (mengenal) pada individu yang belajar.

\section{Aliran Gestalt}

Pembelajaran menurut Gestalt adalah usaha guru untuk memberikan materi pembelajaran sedemikian rupa, sehingga siswa lebih mudah mengorganisirnya menjadi suatu gestalt (pola bermakna). Bantuan guru diperlukan untuk mengaktualkan potensi dan mengorganisir yang terdapat dalam 
diri siswa. Jadi dengan kata lain guru dituntut untuk membimbing siswa agar bisa lebih mudah menerima materi yang diajarkan oleh guru, sehingga bisa belajar dengan baik. Guru harus memberikan contoh ketika mengajarkan materi kepada siswa, sehingga siswa bisa memahami apa yang sedang diajarkan oleh guru.

4. Aliran Humanistik

Pembelajaran adalah memberikan kebebasan kepada siswa untuk memilih bahan pelajaran dan cara mempelajarinya sesuai dengan minat dan kemampuannya.

Pembahasan mengenai hakikat pembelajaran tidak akan terlepas dari pembahasan mengenai belajar dan mengajar. Pendapat tersebut sesuai dengan pendapat Utuh (1987:9) yang menyatakan bahwa pembelajaran hakikatnya adalah aktivitas belajar dan mengajar antara guru dan siswa di bawah interaksi edukatif.

\subsubsection{Ciri-Ciri Pembelajaran}

Ada tiga ciri khas yang terkandung dalam sistem pembelajaran, ialah :

1. Rencana, ialah penataan ketenagaan, material dan prosedur, yang merupakan unsur-unsur sistem pembelajaran, dalam suatu rencana khusus.

2. Kesalingtergantungan (interdependence), antara unsur-unsur sistem pembelajaran yang serasi dalam suatu keseluruhan. Tiap unsur bersifat esensial, dan masing-masing memberikan sumbangannya kepada sistem pembelajaran.

3. Tujuan, sistem pembelajaran mempunyai tujuan tertentu yang hendak dicapai.

Ciri ini menjadi dasar perbedaan antara sistem yang dibuat oleh manusia dan sistem yang alami (natural). Tujuan utama sistem pembelajar an agar siswa 
belajar. Tugas seorang perancang sistem ialah mengorganisasi tenaga, material, dan prosedur agar siswa belajar secara efisien dan efektif. Dengan proses mendesain sistem pembelajaran siperancang membuat rancangan untuk memberikan kemudahan dalam upaya mencapai tujuan sistem pembelajaran tersebut. (Hamalik, 2013:66)

\subsubsection{Siswa (peserta didik)}

Faktor dari siswa yang sangat berpengaruh terhadap keberhasilan belajar adalah bakat, minat, kemampuan, dan motivasi untuk belajar. Winkel (dalam Waluyo, 1994:54) menambahkan intelegensi, sikap, keadaan psikis dan fisik juga sangat berpengaruh terhadap keberhasilan siswa.

\subsubsection{Pembelajaran Seni Musik di Sekolah}

Pembelajaran seni musik merupakan salah satu sub mata pelajaran seni budaya yang tercakup dalam rumpun kelompok mata pelajaran estetika. Pembelajaran sub mata pelajaran ini dimaksudkan untuk meningkatkan sensitivitas, kemampuan mengekspresikan dan kemampuan mengapresiasi keindahan dan harmoni. Kemampuan mengapresiasi dan mengekspresiasikan keindahan serta harmoni mencakup apresiasi dan ekspresi baik dalam kehidupan individual sehingga mampu menikmati dan mensyukuri hidup, maupun dalam kehidupan kemasyarakatan sehingga mampu menciptakan kebersamaan yang harmonis (Tim Pustaka Yustisia dalam Utomo, 2016:1).

\subsubsection{Karakteristik Pembelajaran Seni Musik di Sekolah}

Tujuan pembelajaran seni musik di sekolah umu tentu saja sangat berbeda dengan pmbelajaran seni musik di sekolah kejuruan seni musik yang ada atau 
tempat-tempat kursus musik. Berdasarkan perbedaan tersebut maka dalam bagian ini akan diuraikan tentang karakteristik pembelajaran seni musik di sekolah.

\section{Seni Musik Sebagai Media Pendidikan di Sekolah}

Kesenian menurut (Ki Hadjar Dewantoro dalam Utomo, 2016:11) merupakan hasil karya manusia yang mengandung sifat keindahan. Dalam konteks seni musik, unsur pikiran terlibat aktif manakala komponis menentukan imbanganimbangan, harmoni, irama, dan lain-lain. Sedangkan rasa, biasanya berperan pasif sekalipun menjadi sumber dan penuntundalam proses penciptaan suatu karya seni.

Dalam konteks pendidikan formal saat ini, implementasi pendidikan seni sebagaimana yang diamanatkan dlam Peraturan Pemerintah Republik Indonesia Nomor 19 tahun 2005 yang tertuang dalam Standar Nasional Pendidikan, dalam proses pembelajarannya dilaksanakan melalui mata pelajaran seni budaya. Dalam materi pelajaran seni budaya, aspek budaya tidak dibahas secara tersendiri tetapi terintregasi dengan beberapa pembelajaran seni yang ada. Oleh karena itu, mata pelajaran seni budaya pada dasarnya merupakan pendidikan seni yang berbasis budaya (Utomo, 2016:12).

Menurut (Jazuli dalam Utomo, 2016:12), pendidikan seni memiliki sifat multilingual, multidimensional, dan multikultular. Multilingual bermakna pengembangan kemampuan mengekspresikan diri secara kreatif dengan berbagai bahasa sebagai media berkomunikasi seperti bahasa rupa dalam seni rupa, bahasa bunyi dalam seni musik, bahasa gerak dalam seni tari, bahasa peran dalam seni teater, dan berbagai perpaduan bahasa dalam jenis seni dalam genretertentu.Multidimensional bermakna pengembangan beragam kompetensi 
yang meliputi apresiasi, ekspresi, dan kreasi dengan cara memadukan secara harmonis unsur estetika, logika, kinestetika, dan etika. Sifat multikultular mengandung makna bahwa pendidikan seni menumbuhkembangkan kesadaran dan kemampuan apresiasi terhadap beragam budaya Nusantara dan Mancanegara.

Peranan pendidikan seni dalam pembentukan pribadi peserta didik yang harmonis sangat relevan dengan kebutuhan perkembangan anak. Utamanya dalam mencapai multi kecerdasan yang terdiri atas kecerdasan intrapersonal, interpersonal, visual pasial, musikal. Linguistik, logik matematik, naturalis, kecerdasan adversitas, kecerdasan kreativitas, kecerdasan spiritual dan moral dan kecerdasan emosional (Tim Pustaka Yustisia dalam Utomo, 2016:12).

Pemahaman yang jelas terhadap peran dan hakikat pendidikan seni di sekolah merupakan bagian yang tidak terpisahkan dalam pelaksanaan pendidikan guna mencapai tujuan yang diharapkan. Karena bentuk pendidikan seni yang dikenal sebagai education throught art merupakan bentuk pendidikan yang berupaya untuk memberikan keseimbangan antara intelektualitas dengan sensibilitas dan akal pikiran dengan kepekaan emosi. Bahkan dalam batas-batas tertentu pendidikan seni menjadi sarana untuk mempertajam moral dan watak (Tjetjep Rohendi dalam Utomo, 2016:13).

Pendidikan seni di sekolah selain bertujuan untuk melestarikan kesenian yang ada juga merupakan upaya untuk melaksanakan pendidikan secara lengkap dan seimbang. Lengkap mencakup aspek pengembangan siswa dari sisi jasmani dan rokhani, sedangkan keseimbngan mencakup aspek pengembangan kecerdasan siswa dari sisi intelektual, perasaan, dan kemauan yang terpadu sehingga 
membentuk budi pekerti yang luhur. Oleh karena itu, pembelajaran seni di sekolah tidak mendidik para siswa untuk menjadi seniman dan senimwati.

\section{Tujuan Pembelajaran Seni Musik di Sekolah}

Tujuan pembelajaran pendidikan seni musik di sekolah agar dapat tercapai sesuai dengan tuntutan kurikulum, memerlukan sebuah proses yang komperhensif, yaitu adalah proses pembelajaran yang meniadakan batas-batas antara pembelajaran teori musik dan praktik musik. Oleh karena itu, pelaksanaan pembelajaran seni musik di sekolah hendaknya selalu dilaksanakan melalui pengalaman musik. Pembelajaran seni musik melalui pengalaman musik maksudnya adalah setiap bentuk dan proses pembelajaran musik sebagai upaya untuk mencapai kompetensi dasar dalam kegiatan berapresiasi musik, berekspresi musik, dan berkreasi musik harus dilakukan melalui kegiatan yang terpadu dengan memasukan kegiatan musik sebagai salah satu komponennya. Kegiatan musikal tersebut dapat berupa kegiatan mendengarkan musik (listening). Merespon musik dengan gerak berirama (reading) dan merekam musik (recording), bermain alat musik (playing), menganalisisdan mengapresiasi musik (analyzing and appreciating) (Jamalus, Safrina, dan UNESCO dalam Utomo, 2016:21).

Berdasarkan keterangan diatas dapat disimpulakan bahwa pendidikan seni di sekolah pada dasarnya merupakan proses pembelajaran yang memanfaatkan media seni sebagai alat untuk mencapai tujuan pendidkan. Seperti pembelajaran seni musik di SMA Negeri 1 Moga tujuan pembelajarannya adalah untuk melestarikan seni dan membentuk kepribadian anak sehingga proses kecerdasan 
anak seimbang anatara jasmani, rokhani, intelektual dan emosi yang secara terpadu untuk membentuk budi pekerti yang luhur.

\section{Proses Pembelajaran Seni Musik di Sekolah}

Tugas guru dalam pembelajaran seni musik harus mampu membantu peserta didik menjadi sadar tentang aneka ragam bentuk bunyi, sehingga mereka mampu membantu dan mengekspresikan perasaannya sesuai dengan konteks, sumber daya sosial, dan budaya yang menjadi lingkungannya. Pada tingkat sosial, pendidikan ekspresi esteteika dalam seni musik diharapkan pula mampu menyadarkan peserta didik bahawa bentuk-bentuk audio yang mereka cipta membantu mengungkapkan identitas merekadan keanggotaan mereka dalam dalam suatu kelompok/masyarakat. Bentuk-bentuk audio tersebut dalam banyak hal juga menandai peristiwa-peristiwa penting dalam kehidupannya, sekaligus merefleksikan kebutuhan fisik dan ekspresif dalam kehidupan sehari-hari.

Agar pembelajaran seni musik di sekolah menjadi proses yang bermakna bagi siswa maka diperlukan kreativitas guru dalam mendisain pelaksanaannya. Oleh karena itu, beberapa aspek penting dalam pelaksanaan pembelajaran seperti: (1) kreativitas guru dalam menentukan dan memilih materi pembelajaran agar sesuai dengan kebutuhan siswa, tuntutan kurikulum, perkembangan dan kemampuan siswa; (2) kreativitas guru dalam mengembangkan strategi dan kegiatan pembelajarab yang tercermin dalam metode, bentuk aktivitas guru dan siswa, dan (3) kreatvitas guru dalam memanfaatkan dan mengembangkan media dan sumber belajar yang bermuara pada terciptanya suatu proses pembelajaran yang efektif dan efisien perlu mendapatkan perhatian (Utomo, 2016:21). 
Ada beberapa pendekatan pembelajaran yang relevan secara metodologis dapat dilakukan dalam pembelajaran seni musik di sekolah, seperti: (1)Collaborating across the art; (2) individual and group learning in compostion and performace; (3) critical evaluation;(4) improving, for example: musical conversations; (5) aural thingking development, for example: playback, focused listening; (6) peer teaching; (7) modeling; (8) self and peer evaluation; dan (8) group discussion centred around focused listening, e.g: identifying and describing the elemens of music, the porpuses and functions of music, comparative analysis of music and aesthetic responses to music (UNESCO dalam Utomo, 2016:21).

Berdasarkan keterangan diatas menunjukkan baha berdasarkan tujuan dan karakteristik pembelajaran seni musik di sekolah, maka kreativitas guru dalam mendisain pembelajaran menjadi salah satu kunci keberhasilan pembelajaran seni musik. Meskipun pembelajaran seni musik tidak bisa terlepas dan praktik musik. Berbagai bentuk aktivitas musikal dilakukan dan digunakan sebagai media untuk memberikan pengalaman musik. Dari pengalaman musik inilah tujuan pembelajaran seni musik dalam ranah kognitif, afektif, dan psikomotor diharapkan dapat dicapai. Selain itu, pembelajaran seni musik harus dapat menajdi sarana bagi siswa dalam mengekspresikan diri, membangun kepercayaan diri dalam lingkungan yang terkendali, dan dapat mendorong anak agar bertanggungjawab dalam membuat keputusan kreatif (Sheppard dalam Utomo, 2016:20).

\subsubsection{Pembelajaran Apresiasi, Ekspresi, dan Kreasi Musik di sekolah}

Kompetensi mengapresiasi, mengekspresikan dan berkreasi musik sebagai bagian penting dalam pembelajaran seni musik di sekolah semestinya tidak 
dilakukan secara dikotommik. Dalam proses pembelajaran musik ketiga aspek tersebut secara bersamaan saling melengkapi dan bekerja dalam memberikan pengalaman musik yang bermakna bagi siswa. Terkait dengan tiga konsep yang sangat penting dalam pelaksanaan pembelajaran seni musik tersebut, dapat dijelaskan sebagai berikut (Utomo, 2016:8-9).

\subsubsection{Apresiasi musik}

Berapresiasi (to appreciate) berarti menghargai. Pembelajaran apresiasi merupakan bentuk pembelajaran pengembangan emosi yang dapat mengembangkan potensi afeksi siswa sehingga bermanfaat untuk memperoleh pengalaman baru, memperkaya jiwa, menanamkan cinta bangsa, dan cinta sesama, serta meningkatkan ketahanan budaya.

Berbagai pengalaman musik tersebut sebagai sebuah proses melatih siswa untuk berani mengungkapkan potensi dan kreasinya melalui media musik, mengembangkan persepsi, imajinasi, dan daya fantasinya bagi potensi dirinya, memahami fungsi seni dalam berbagai konteks sosial budaya, dan memahami keragaman seni musik yang ada.

Tahap-tahap proses pembelajaran apresiasi dapat dilakukan sebagai berikut:

\subsection{Tahap Penikmatan}

Pada tahap ini, kegiatan pembelajaran dilakukan dengan cara memberikan penglaman musik kepada siswa baik melalui kegiatan mendengarkan atau pengamatan terhadap karya musik sehingga terjadi proses psikis pada diri siswa. Ada empat macam cara mendengarkan musik yakni : (1) mendengarkan secara 
pasif; (2) mendengarkan secara menikmati; (3) mendengarkan secara emosional; dan (4) mendengarkan secara perseptif.

Mendengarkan secara pasif adalah berarti apabila beberapa situasi musik tidak diharapkan menuntut perhatian sepenuhnya dari pendengar, sedangkan mendengarkan secara menikmati adalah suatu aktivitas mendengarkan musik yang menuntut perhatian lebih besar daripada sekedar mendengarkan secara pasif, sehingga pendengar dapat mencapai kesenangan dari kesadaran untuk mencapai keindahan bunyi. Mendengarkan secara emosional adalah suatu sikap pendengar atas reaksi-reaksinya terhadap musik, emosi-emosi serta ungkapan-ungkapan yang dibangkitkan oleh musik. Adapun mendengarkan secara perseptif adalah suatu cara mendengarkan musik yang bila dibandingkan dengan ketiga cara sebelumnya cara ini lebih menuntut konsentrasi serta kesadaran yang tajam tentang apa yang terjadi pada musik. Cara mendengar seperti ini membawa pendengar para apresiasi yang sebenarnya, karena pada saat mendengarkan seseorang mengetahui untuk apa mendengarkan, dan memahami apa yang didengar (Miller dalam Utomo, 16:9).

\subsection{Tahap Pemahaman}

Pada tahap ini, proses pembelajaran berlangsung melalui kegiatan mengidentifikasi, menganalisis, menemukan hal-hal yang unik, khas dan menarik, sehingga menimbulkan persepsi musikal pada diri siswa. 
1. Tahap Penghayatan

Tahap penghayatan berlangsung manakala terjadi proses seleksi atau obyek (musik) yang menyebabkan terjadinya proses penyesuaian antara nilai yang ada pada obyek (musik) dengan persepsi subyek (siswa).

1. Tahap Penilaian

Pada Tahap ini, pembelajaran berlangsung manakala siswa dihadapkan pada proses menganalisis dan menakar bobot nilai seni yang ada di dlam obyek melalui berbagai unsur musikal yang ada (Jazuli dalam Utomo,2016:9).

\subsubsection{Ekpresi Musik}

Seni merupakan salah satu media yang dapat digunakan untuk mengekspresikan perasaan. Namun kualitas perasaan yang diekspresikan dalam seni bukan merupakan perasaan individual, melainkan perasaan yang universal. Perasaan yang dapat dihayati oleh orang lain sekalipun jenis perasaan tersebut belum pernah dialaminya (Sumardjo dalam Utomo,2016:10).

Dalam pembelajaran seni musik kegiatan berekspresi dapat dilakukan melalui beberapa cara, seperti: (1) kegiatan merespon musik dengan gerak berirama, yakni kegiatan yang dilakukan dengan cara menggerakan bagian anggota tubuh (tangan, kaki, badan, dan kepala) sesuai dengan irama musik yang ada; (2) bernyanyi, yakni merupakan kegiatan olah vokal yang dilakukan dengan memperhatikan beberapa aspek seperti intonasi, artikulasi, pernafasan, phrasering, dan pembawaan; dan (3) membaca notasi musik, adalah kegiatan membaca simbolsimbol musik atau notasi musik dari sebuah karya musik. Aktivitas ini bisa dilakukan melalui kegiatan bernyanyi atau bermain instrumen musik. Bermain 
alat musik sebagai aktivitas musikal adalah kegiatan musik yang dilakukan dengan cara memainkan alat musik yang ada. Alat musik tersebut bisa berupa alat musik ritmis, melodis, maupun harmonis (Jamalus, Miller, dan Rudy, M.Y dalam Utomo,2016:10).

\subsubsection{Kreasi Musik}

Berkreasi pada hakekatnya adalah "melahirkan sesuatu", atau menciptakan sesuatu yang belum ada. Dalam melahirkan atau menciptakan sesuatu dibutuhkan kemampuan kreasi atau kreatif, yaitu suatu kualitasyang berhubungan dengan sensitivitas, kelancaran (fluency), fleksibilitas, originalitas, pengaturan, analisis, sintesis, serta elaborasi (Jazuli dalam Utomo, 2017:10).

Kreativitas dibutuhkan dalam memecahkan masalah yang bersifat divergen, yakni kemampuan berfikir tentang sesuatu dengan cara yang baru untuk dapat menemukan pemecahan masalah yang unik (Jakop dalam Utomo, 2016:10). Penadapat lain mengenai kreativitas adalah kemampuan membuat dan membangun sesuatu melalui sejumlah ilham-ilham baru, baik dalam rangka seni maupun ilmu alam dan lain-lain (Mack dalam Utomo, 2016:10).

Dalam bidang seni, kreativitas sebagai suatu alat yang mendidik demi perkembangan kemandirian siswa, sehingga sikap kreatif atau keinginannya menjadi landasan bagi perilaku siswa selanjutnya baik dalam bidang profesi musik maupun bidang-bidang lainnya. Dengan kata lain kreativitas tidak diarahkan pada suatu hasilnya yang telah ditentukan dari sebelumnya, melainkan pembelajaran kreativitas selalu berhubungan dengan proses kemandirian seorang siswa serta sikapnya (Utomo, 2016:11). 
Seni musik sebagai media pengembangan kreativitas, sifat-sifat imaginasi dan permainan yang melekat pada seni menegaskan adanya suatu kebebasan berfikir dan pengungkapannya.

\subsubsection{Pembelajaran Drum Secara Virtual di SMA Negeri 1 Moga}

\subsubsection{Pengertian Virtual}

Virtual menurut Kamus Besar Bahasa Indonesia (KBBI) adalah tidak nampak. Virtual berasal dari kata visual, yang artinya adalah proses pengubahan suatu konsep dan pengeungkapan suatu gagasan atau perasaan dengan menggunakan bentuk gambar, tulisan grafik dan lainnya agar dapat dilihat dengan indra penglihatan (mata) untuk di sajikan.

\subsubsection{Pengertian Alat Musik Drum}

Alat musik drum adalah salah satu alat musik yang sering dipakai disekolahsekolah sebagai media pembelajaran musik baik intra maupun ekstra kurikuler. Alat musik ini biasanya digunakan dalam bentuk kegiatan band, drum band atau marching band. Ketiga bentuk kegiatan tersebut merupakan kegiatan bermusik yang sangat menarik bagi siswa di sekolah-sekolah di berbagai tingkatan. Alat musik drum adalah alat yang digunakan dengan cara dipukul. Alat musik ini terdiri dari berbagai jenis seperti: snare drum, bas drum, tom-tom, dan lain sebagainya ( Haryono dan Langlang Handayani, 2006: 2).

Menurut (Wikipedia, 2017) bagian-bagian drum, fungsi alat musik drum, konstruksi drum, dan jenis-jenis drum adalah sebagai berikut :

\section{Bagian-bagian dari Drum}

1.1 Bass Drum 


\subsection{Snare Drum}

1.3 Tom-tom. Tom-tom ini terbagi menjadi dua yaitu Mounted atau rack tom, untuk tom-tom yang menggunakan penopang, dan floor tom untuk tom-tom yang menggunakan kaki.

1.4 Cymbal, untuk cymbal terbagi lagi ada hi hat, crash cymbal, chinese cymbal, splash cymbal, dan effect cymbal.

1.5 Hardware, antara lain kursi drum, stand cymbal, pedal, stand hi hat, tom holder

1.6 Double Pedal, yaitu pedal drum yang jumlahnya ada dua.

Biasanya drum dibagi berdasarkan kelasnya, ini dibagi menurut harganya. Ada yang disebut entry level atau drum untuk pemula. Ada juga drum untuk kelas menengah dan untuk kelas atas. Biasanya drum untuk kelas menengah dan kelas atas tidak disertai dengan cymbal, karena untuk cymbal harus membeli sendiri.

\section{Fungsi Alat Musik Drum}

Fungsi alat musik drum menurut (Ryanto, 2014:9) adalah sebagai berikut :

\subsection{Snare}

Snare merupakan unsur yang paling vital dalam drum, karena snare merupakan bagian penentu dalam menentukan ketukan pada saat bermain drum. Snare pun terdiri dari berbagai variasi ukuran antara 10 hingga 15 derajat. Pada snare terdapat bagian yang sangat penting yaitu snare wireataustainer yang terdapat dibawah snare. Jika kita memukul sisi atas pada drum, maka stainer yang dirapatkan pada bawah snare akan berinteraksi yang menghasilkan bunyi yang sangat nyaring. 


\subsection{Bass Drum}

Bass Drum adalah bagian dari drum yang merupakan bagian yang sangat vital dari drum. Karena bass drum mempunyai fungsi yang hampir sama dengan snare drum, yaitu sebagai penentu ketukan pada saat kita bermain drum. Bass drum biasanya dimainkan oleh kaki kanan kita (standar) atau bisa juga dimainkan oleh kedua kaki kita (tergantung kebutuhan). Dalam memainkan bass drum kita dibantu oleh alat yaitu pedal.

\subsection{Tom-tom}

Tom-tom pada drum merupakan kelengkapan pada drum set, dimana drummer dapat lebih leluasa memvariasikan pukulan. Tom-tom muncul pada decade 30 -an, pada awalnya tidak bisa dituning. Tom-tom terdiri dari bermacam-macam ukuran dan bahan yang berbeda, biasanya tom-tom terbuat dari kayu maple atau birch.

\subsection{Cymbal}

Terdiri dari hihat cymbal, crash cymbal, splash cymbal, china cymbal, dan bell cymbal.

\section{Kontruksi Drum}

Shell atau selongsong adalah pembentuk dari sebuah drum. Shell atau selongsong ini bisa terbuat dari kayu atau dari besi. Karakter dari shell ini akan mempengaruhi kepada suara yang nantinya dihasilkan oleh drum tersebut. Biasanya shell yang terbuat dari besi karakter suaranya adalah tajam dan attack, sementara karakter suara dari drum yang terbuat dari kayu adalah hangat. 


\section{Jenis-jenis Drum}

Menurut (Wikipedia 2017) jenis-jenis drum adalah sebagai berikut : (1) aburukowo; (2) ashiko; (3) bodhran; (4) bougarabou; (5) cajon; (6) chenda; (7) conga; (8) davul; (9) dhol; (10) djembe; (11) dunun; (12) mridangam; dan (13) taiko.

\subsubsection{Pengertian Virtual Drum yang digunakan guru sebagai acuan}

Virtual musik adalah musik yang dihasilkan atau dimainkan dengan cara digital dan tidak nyata dengan bantuan software untuk memainkannya. Kebanayakn di zaman sekarang sudah banyak musisi yang menggunakan virtual musik sehingga dengan mudah untuk recording. Bukan hanya dalam recording, dalam mixing pun virtual musik biasanya lebih sempurna dibandingkan dengan bermain secara live atau langsung dengan nyata (Nurul Imansyah, 2013).

Menurut Witharto (2012) Virtual drum merupakan simulasi aplikasi drum yang mirip dengan drum aslinya, dengan sejumlah efek dan gambar, dengan adanya virtual drum saja belum cukup pemula untuk memahami materi drum karenanya virtual drum akan mengajarkan pemula ke hal praktek saja dan tidak mengajarkan materi oleh sebab itu, dibuatlah media pembelajaran alat musik drum yang bermaterikan tentang pengenalan komponen drum, teknik memukul, notasi, ritme dan lainnya.

Virtual drum ini di buat oleh virtual drumming, bagi pemula yang ingin belajar bermain drum meskipun tidak memiliki satu set alat musik drum, bisa mencoba dengan games virtual drum online. Cara memainkannya hanya 
membutuhkan jari-jari saja. Dengan Virtual drum ini, pemain akan merasakan sensasi seperti bermain drum sesungguhnya, karena pada game virtual ini suara yang dihasilkan dari drum virtual tersebut seperti suara drum yang nyata serta bentuknya yang sama persis dengan aslinya (Zamaludin, 2013).

Menurut Williancesna (2012) ada tiga jenis aplikasi virtual drum antara lain sebagai berikut :

1. Drum Games, untuk memainkannya pemain cukup memilih drum games kemudian terserah pemain memilih drum set yang diinginkan, dan pemain bisa men-set pada keyboard settingan key nya.

2. Drum Lessons, yang berfungsi sebagai tempat untuk pemain yang ingin belajar dasar-dasar teori dalam bermain drum. Pada drum lesson, pemain diajarkan bagaimana mengontrol stick, memainkan snare, hi hat, cymbal, tom-tom, bass dan double pedal/doubel bass, serta belajar dasar-dasar musik rock, jazz dan dasar-dasar musik lainnya.

3. Live Drum, dengan live drum ini pemain akan merasakan bermain drum seperti diatas panggung yang sebenarnya secara live. Karena pada drum set ini bukan hanya suara drum saja yang terdengar, tetapi selain itu suara soraksorak penonton/fans yang membuat pemain merasa seperti sedang konser di atas panggung.

\section{Jenis Software yang di gunakan dalam Virtual Drum}

Menurut Nurul Imansyah (2013) jenis software yang digunakan dalam aplikasi virtual drum adalah sebagai berikut : 


\subsection{FL Studio (FruityLoop)}

Software FL Studio (FruityLoop) ini sangat unggulan, karena sudah tersedia hampir semua alat musik ada di software ini, namun tinggal bagaimana kita memanfaatkannya dengan kreatif dan sebaik mungkin.

\subsection{Nuendo}

Nuendo adalah software virtual musik yang digunakan untuk membuat suara drum (Drum Virtual). Sebenarnya masih banyak plugin yang tersedia pada software nuendo, namun banyak yang berpendapat software ini paling cocok untuk drum.

\subsection{Acoustica BeatCraft}

Software Acoustica BeatCraft ini sangat instan dalam virtual drum, tinggal bagaimana kita memilih tipe ketukan dan sebagainya (Software yang sangat cocok untuk pemula).

\section{Fungsi Virtual Drum}

Berikut fungsi virtual musik drum menurut (Nurul Imansyah, 2013) adalah sebagai berikut :

2.1 Suaranya lebih jernih dan rapih.

2.2 Lebih mudah diatur dalam hal tempo. 
2.3 Tidak susah mencari alat musik drum hingga jutaan rupiah dengan software virtual drum ini pemain bisa belajar bermain drum tanpa harus memiliki atau memegang alat musik drum yang aslinya.

2.4 Mudah dalam hal mixing dan recording karena dengan virtual musik drum lebih rapih dibandingkan memainkan drum secara live atau langsung.

\section{Kelebihan dan Kekurangan Virtual Drum}

Kelebihan dan kekurangan virtual drum menurut Zamaludin (2013) adalah sebagai berikut :

\subsection{Kelebihan Virtual Drum}

Kelebihan dari memakai aplikasi virtual drum adalah sebagai berikut :

3.1.1 Tampilan grafis dan suara yang cadas karena sangat sesuai dengan aslinya.

3.1.2 Kumpulan drum set yang cukup banyak seperti drum set Joey Jodirson, Michael Bland, Jimmy The Rev Sullivan dan lain sebagainya.

\subsection{Kekurangan Virtual Drum}

Kekurangan dari memakai aplikasi virtual drum adalah karena kecadasan dari virtual itu sendiri, jika aplikasi virtual drum ini memakai komputer yang speknya biasa saja makan suara yang akan dihasilkan tidak bisa maksimal, karena virtual drum ini tidak bisa bkerja sama dengan input komputer tersebut. 


\subsubsection{Evaluasi}

Untuk dapat menetukan tercapai tidaknya tujuan pembelajaran, perlu dilakukan usaha atau tindakan penilaian atau evaluasi. Evaluasi adalah kegiatan yang terencana untuk mengatahui keadaan suatu objek dengan menggunakan instrumen dan membandingkan hasilnya dengan tolak ukur untuk memperoleh kesimpulan (Fathurrohman, 2007:75). Menurut Nana Sudjana dalam Fathurrohman (2007:75) menjelaskan bahwa evaluasi pada dasarnya memberikan pertimbangan atau harga atau nilai berdasarkan kriteria tertentu. Tujuan tersebut dinyatakan dalam rumusan tingkah laku yang diharapkan memiliki peserta didik setelah menyelesaikan pengalaman belajarnya.

Sejauh mana keberhasilan seseorang memberikan materi dan sejauh mana siswa menyerap materi yang disajikan dapat diperoleh informasi melalui evaluasi. Evaluasi yang baik haruslah didasarkan pada tujuan pembelajaran (instructional) yang diterapkan oleh pendidik dan kemudian benar-benar diusahakan pencapaiannya oleh pendidik dan peserta didik (Suke Silverius dalam Fathurrohman, 2007:75).

Menurut Dimyati (2006:221) evaluasi pembelajaran merupakan suatu proses untuk menentukan jasa, nilai atau manfaat kegiatan pembelajaran melalui kegiatan penilaian dan/atau pengukuran. Evaluasi pembelajaran mencakup pembuatan pertimbangan tentang jasa, nilai, dan manfaat program, hasil dan proses pembelajaran.

Evaluasi pembelajaran adalah evaluasi terhadap proses belajar mengajar. Secara sistematik, evaluasi pembelajaran diarahkan pada komponen-komponen 
sistem pembelajaran, yang mencakup komponen input, yaitu perilaku awal (entry behavior) siswa, komponen input instrumental yaitu kemampuan profesional guru/tenaga kependidikan, komponen kurikulum (program studi, metode, media), komponen administratif (alat, waktu, dana); komponen proses adalah prosedur pelaksanaan pembelajaran; komponen output adalah hasil pembelajaran yang menandai ketercapaian tujuan pembelajaran. Dalam hal ini perhatian hanya ditujukan pada evaluasi terhadap komponen proses dalam kaitannya dengan komponen input instrumental (Hamalik, 2013:171).

Utomo dkk. (2014:6) Menjelaskan komponen evaluasi merupakan komponen yang berfungsi untuk mengetahui apakah tujuan yang telah ditetapkan telah tercapai atau belum. Dan juga berfungsi sebagai umpan balik untuk perbaikan strategi yang telah ditetapkan. Kedua fungsi evaluasi tersebut merupakan evaluasi sebagai fungsi sumatif dan formatif.

Dalam pembelajaran seni musik di SMA Negeri 1 Moga perlu dilakukannya evalusi pembelajaran khususnya alam pembelajaran drum yang berfungsi mengukur atau menilai sejauh mana pembelajaran itu berhasil sesuai dengan tuntutan kurikulum pembelajaran.

\subsubsection{Kerangka Berpikir}

SMA Negeri 1 Moga merupakan satu-satu nya sekolah yang berstatuskan Negeri yang berada di kecamatan Moga Kabupaten Pemalang.Di SMA Negeri 1 Moga terdapat pembelajaran seni budaya (musik) sesuai dengan kurikulum yang berlaku, namun meskipun pembelajaran dilakukan oleh guru yang bukan dari akademisi musik, guru tersebut mempunyai kretaivitas dalam pembelajaran virtual 
drum.. Dalam penelitian ini peneliti mengkaji tentang Kreativitas Guru dalam Pembelajaran Virtual Drum di SMA Negeri 1 Moga Kecamatan Moga Kabupaten Pemalang yang dilihat dari komponen-komponen kreativitas guru dalam pembelajaran virtual drum yaitu guru, siswa (peserta didik), kreativitas guru, dan pembelajaran virtual drum.

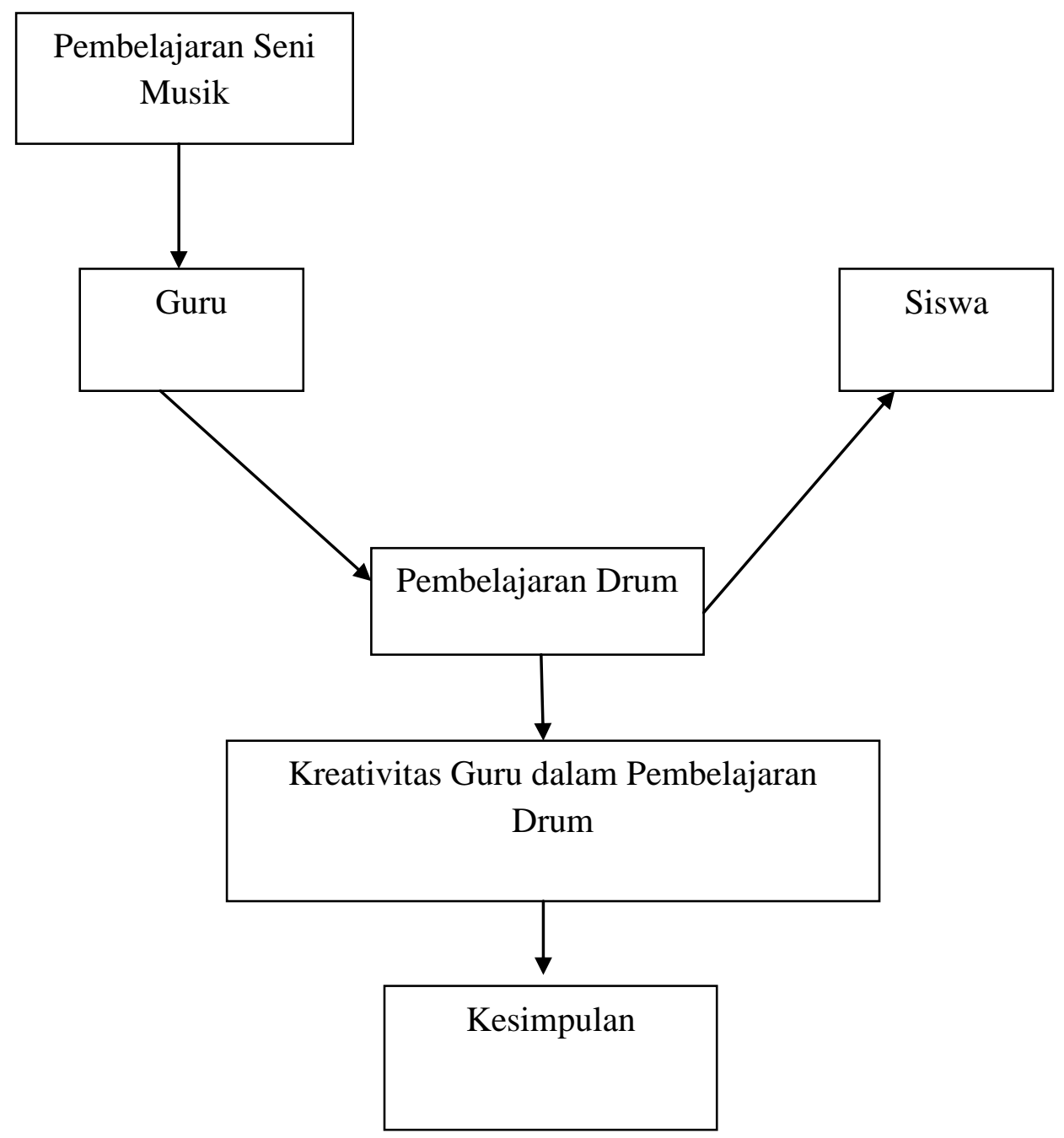

Bagan 2.1 Kerangka Berfikir 
Bagan 2.1 di atas menjelaskan tentang kerangka berpikir yang di pakai oleh peneliti dalam melakukan penelitian di SMA Negeri 1 Moga. Pembelajaran seni musik di SMA Negeri 1 Moga merupakan sub materi dari mata pelajaran Seni Budaya yang sudah ada di kurikulum, dan pembelajaran dilakukan oleh guru. Guru adalah tenaga pendidik yang memebrikan sejumlah ilmu dan pengetahuan kepada peserta didik (siswa). Sebelum guru melaksanakan pembelajaran seni musik kepada siswa, guru terlebih dahulu mempersiapkan materi yang akan diajarkan kepada siswa. Karena latar belakang guru tersebut bukan dari pendidikan seni musik, maka pembelajaran tidak sesuai dengan ateri yang ada di buku ajar Seni Budaya dan disesuaikan dengan kemampuan guru. Guru di SMA Negeri 1 Moga dapat memainkan alat musik drum, melihat kemampuan yang dimiliki guru memilih pembelajaran sebagai materi pembelajaran seni musik kepada siswanya. Sebelum guru memulai pembelajaran drum, guru harus menggunakan kreativitas yang dimiliki oleh guru agar guru mudah memebrikan materi pembelajaran drum kepasa siswa, sehingga siswa yang telah mendapatkan materi pembelajaran drum dapat memainkan drum. 


\section{BAB III}

\section{METODE PENELITIAN}

\subsection{Pendekatan Penelitian}

Pendekatan penelitian yang dipilih dalam penelitian ini adalah deskriptif kualitatif, yaitu suatu metode yang meneliti status kelompok manusia, suatu obyek, suatu set kondisi atau sistem pemikiran ataupun suatu kelas peristiwa pada masa sekarang. Menurut Bogdan dan Taylor dalam Moleong (1990:3) mendeskripsikan metode kualitatif sebagai prosedur penelitian yang menghasilkan data deskriptif berupa kata-kata tertulis atau lisan dari orang-orang dan perilaku yang dapat diamati. Deskriptif adalah data yang dikumpulkan berupa kata-kata, gambar dan bukan angka-angka (Moleong, 1990:6).

Fokus dalam penelitian ini adalahmenguraitentang kreativitas guru dalam pembelajaran drum di SMA Negeri 1 Moga Pemalang, oleh karena itu penelitian ini menggunakan metode deskriptif kualitatif, karena fokusnya adalah kreativitas musikologi.

\subsection{Lokasi dan Sasaran Penelitian}

Lokasi penelitian ini adalah diSMA Negeri 1 Moga Kelurahan Banyumuudal Kecamatan Moga Kota Pemalang. Sasaran penelitian ini adalah kreativitas guru Sekolah Menengah Atas dalam pembelajaran drum di SMA Negeri 1 Moga Pemalang. 


\subsection{Sumber Data}

Sumber data dalam penelitian ini adalah subjek atau bahan yang dapat memberikan informasi mengenai tujuan penelitian. Sumber data yang diperoleh bersifat tertulis maupun lisan. Data tertulis meliputi buku, majalah, laporan penelitian, kamus, serta jurnal. Data yang bersifat lisan meliputi wawancara dengan guru pengajar SMA Negeri 1 Moga Pemalang. Data data yang berhubungan dengan kegiatan siswa yaitu berupa foto kegiatan belajar mengajar, partitur pembelajaran dan lain sebagainya.

\subsection{Teknik Pengumpulan Data}

Teknik pengumpulan data adalah suatu proses pengadaan data primer untuk keperluan penelitian, pengumpulan data adalah prosedur yang sistematik dan standar untuk mengolah data yang diperlukan (Nasir, 1985: 21). Dalam penelitian ini data dikumpulkan dengan teknik antara lain :

\subsubsection{Observasi}

Pengumpulan data dengan observasi adalah cara pengambilan data dengan menggunakan berbagai indera tanpa pertolongan alat standar untuk keperluan tersebut. Menurut Arikunto (1993:123) metode observasi atau pengamatan meliputi kegiatan pemusatan perhatian terhadap sesuatu objek dengan menggunakan seluruh alat indera. Dalam penelitian ini observasi dilakukan dengan cara mengamati kreativitas guru dalam pembelajaran drum di SMA Negeri 1 MogaPemalang .

Observasi langsung ini dilakukan untuk mendapatkan secara langsung datadata tentang kreativitas guru dalam pembelajaran drum yang dibutuhkan selama 
berlangsungnya kegiatan yang diamati tersebut. Selain mengamati kegiatan dari observasi langsung ini penulis dapat langsung menentukan Bapak Erwanto, S.Pd selaku guru di SMA Negeri 1 Moga yang dianggap mampu menjadi narasumber dalam pengumpulan data-data yang dibutuhkan penulis. Peneliti akan melakukan pengambilan data berupa foto-foto dan video saat proses pembelajaran berlangsung yang berada di SMA Negeri 1 Moga.

\subsubsection{Wawancara}

Wawancara (Interview) adalah sebuah dialog yang dilakukan pewawancara (Interviewer) untuk memperoleh informasi dari terwawancara (Arikunto, 1993:145). Tujuan utama melakukan wawancara adalah untuk menyajikan konstruksi saat sekarang dalam suatu konteks mengenai para pribadi, peristiwa, aktivitas, organisasi, perasaan, motivasi, keterlibatan, dan sebagainya. Data yang dikumpulkan dalam penelitian ini yaitu mengenai kreativitas guru dalam pembelajaran drum di SMA Negeri 1 Moga Pemalang. Percakapan itu dilakukan oleh dua pihak, yaitu pewawancara (interviewer) yang mengajukan pertanyaan dan yang diwawancarai (be interviewed) yang memberikan jawaban atas pertanyaan itu.

Pertanyaan secara khusus ditujukan kepada informan peneliti Bapak Erwanto, S.Pd selaku guru di SMA Negeri 1 Moga. Berikut pertanyaanpertanyaan yang diajukan oleh peneliti kepada narasumber (1) Cara guru menyampaikan materi kepada murid, (2) Apa yang dilakukan guru saat pembelajaran drum, (3) Metode apa yang diterapkan oleh guru dalam pembelajaran drum, (4) Properti yang digunakan saat mengajar, (5) Sumber 
belajar, (6) Faktor pendukung kreativitas guru, (7) Faktor penghambat kreativitas guru.

Metode pencatatan dalam penelitian ini menggunakan beberapa media yaitu, media pencatat berupa buku tulis, perekam suara dan kamera digital yang akan digunakan untuk merekam dan mendokumentasikan hasil penelitian di SMA Negeri 1 Moga. Dengan menggunakan media tersebut diharapkan dapat menghadirkan data yang jelas dan valid serta sebagai bukti dari pelaksanaan penelitian terhadap kreativitas guru dalam pembelajaran drum di SMA Negeri 1 Moga Pemalang. Peneliti mengakui bahwa tidak semua aktivitas pengambilan data dapat direkam dan di dokumentasikan semuanya.

\subsubsection{Dokumentasi}

Dokumentasi adalah teknik pengumpulan data yang berhubungan dengan dokumen baik dalam bentuk laporan, surat-surat resmi maupun catatan harian dan sebagainya.Menurut Moleong (1990:161). Dokumentasi adalah bahan tertulis atau film lain dari record yang tidak dipersiapkan karena adanya permintaan seorang penyidik. Dokumentasi digunakan untuk memperluas penelitian, karena alasanalasan yang dapat di pertanggung jawabkan.

Dengan teknik tersebut peneliti dapat mempelajari dokumen yang berhubungan dengan materikreativitas guru dalam pembelajaran drum di SMA Negeri 1 Moga Pemalang. Macam-macam dokumen yang digunakan peneliti dalam melakukan penelitian adalah buku-buku seperti buku panduan skripsi, buku Musik, RPP sebelum melaksanakan pembelajaran, kemudian foto-foto yang diberikan oleh narasumber yaitu guru di SMA Negeri 1 Moga. Berkenaan dengan 
penelitian ini, dokumen tersebut diharapkan dapat memberikan uraian kreativitas guru dalam pembelajaran drum di SMA Negeri 1 Moga Pemalang. Dokumendokumen yang akan disertakan dalam penelitian ini antara lain foto, data media pembelajaran dan pedoman wawancara yang terdapat pada lembar lampiran.

\subsubsection{Studi Pustaka}

Studi pustaka merupakan alat pendukung berupa buku atau artikel-artikel yang digunakan untuk mendukung memberikan penjelasan dan melengkapi segala hal yang berkaitan dengan penelitian yang dilakukan.

Menurut Nasir (1985:122), studi pustaka merupakan langkah yang penting dimana setelah seorang peneliti menetapkan topik penelitian, langkah selanjutnya adalah melakukan kajian yang berkaitan dengan teori yang berkaitan dengan topik penelitian. Dalam pencarian teori, peneliti akan mengumpulkan informasi sebanyak-banyaknya dari kepustakaan yang berhubungan. Sumber pustaka dapat diberoleh melalui: buku-buku jurnal, majalah, hasil-hasil penelitian (tesis, dan disertasi) dan sumber-sumber lainya yang sesuai dengan kreativitas guru dalam pembelajaran drum yang ada dalam media massa dan internet.

\subsection{Teknik Keabsahan Data}

Peneliti dalam melakukan teknik keabsahan data dengan menggunakan trianggulasi yaitu teknik keabsahan data yang memanfaatkan sesuatu yang lain diluar data untuk keperluan pengecekan atau sebagai pembanding terhadap data tersebut (Moloeng, 1996:178).

Pengumpulan data dalam penelitian dengan cara observasi, pencatatan dan wawancara dengan informan, oleh karena itu untuk mendapatkan data yang valid 
dan ada kecocokan satu sama lain, peneliti mengadakan triangulasi sumber data melalui pemeriksaan terhadap sumber lainnya yaitu membandingkan data hasil pengamatan dengan data hasil wawancara.

Uji kredibilitas dalam penelitian ini menggunakan teknik triangulasi. Teknik triangulasi meliputi 3 unsur penting dalam mendukung keabsahan data yang diperlukan yaitu sumber, metode dan teori.

\subsubsection{Sumber}

Triangulasi dengan sumber berarti membandingkan dan mengecek balik derajat kepercayaan suatu informasi yang diperoleh melalui waktu dan alat yang berbeda dalam penelitian kualitatif (Patton dan Moleong 2013: 330). Pengecekan balik derajat kepercayaan dapat dilakukan dengan tiga cara. Pertama membandingkan data hasil pengamatan dengan data hasil wawancara. Kedua, membandingkan dengan apa yang dikatakan pada waktu wawancara dengan apa yang dilakukan dengan pengamatan. Ketiga, membandingkan hasil wawancara dengan isi dokumen. Langkah-langkah peneliti dalam melakukan pemeriksaan keabsahan data adalah sebagai berikut:

Peneliti melakukan pemeriksaan keabsahan data dengan cara mencocokan hasil wawancara dengan guru dan kepala sekolah SMA Negeri 1 Moga dengan pengamatan yang dilakukan peneliti di SMA Negeri 1 Moga Pemalang.

\subsubsection{Metode Pengamatan}

Metode pengamatan yang peneliti gunakan adalah metode pengamatan bebas dimana peneliti tidak memiliki hubungan apapun dengan sasaran peneliti. Peneliti hanya menemui sasaran penelitian dimana mereka berada dan kemudian 
mengobservasi secara sistematis kegiatan mereka.Metode ini menggunakan teknik pengamatan yang mengharuskan peneliti tidak boleh terlibat dalam hubunganhubungan emosi pelaku yang menjadi sasaran penelitiannya. Peneliti dalam hal ini tidak ada hubungan apapun dengan para pelaku yang diamatinya. Setelah data diperolehdari beberapa sumber informasi maka peneliti melakukan pengecekan data hasil dari wawancara guru dan kepala sekolah SMA Negeri 1 Moga tersebut dengan beberapa sumber lain yang dapat dipertanggungjawabkan kebenarannya dengan metode yang sama.

\subsubsection{Teori}

Penggunaan teori dalam teknik triangulasi berdasarkan anggapan bahwa fakta tidak dapat diperiksa derajat kepercayaannya dengan satu atau lebih teori (Lincon dan Guba dalam Moleong, 2013:331). Peneliti dalam penelitian ini menggunakan beberapa sumber buku contohnya buku tentang musik yang berjudul "Teori Musik Dasar" sebagai acuan teori untuk membahas permasalahan tentang penelitian Kreativitas Guru dalam Pembelajaran Drum di SMA Negeri 1 Moga Pemalang.

\subsection{Teknik Analisis Data}

Analisis data kualitatif adalah analisis yang dilakukan pada data yang berwujud kata-kata dan bukan rangkaian angka serta dalam analisisnya tetapmenggunakan kata-kata yang biasanya disusun kedalam teks yang diperluas (Milles dan Huberman dalam Rohidi, 1992: 15-16). Untuk memberi bobot yang lebih tinggi pada metode ini, maka data atau fakta yang dikemukakan harus diberi arti dengan tidak sekedar menyajikan secara deskriptif. 
Proses analisis data dilakukan secara sistematik dan serempak, mulai dari proses pengumpulan data, mereduksi, mengklasifikasi, mendeskripsi dan penyajian data, serta penarikan kesimpulan dan interprestasi semua informasi yang secara selektif dan terkumpul (Milles dan Hubernan dalam Rohidi, 1993:1621). Analisis data diarahkan untuk memberikan penjelasan secara keseluruhan tentang kreativitas guru dalam pembelajaran drum di SMA Negeri 1 Moga Pemalang. Semuanya dijadikan sebagai pokok permasalahan atau sasaran dalam penelitian.

Dalam analisis ini, menurut Milles dan Huberman dalam Sumaryanto (2001:21), teknik analisis data yang digunakan yaitu mencakup tiga komponen pokok yaitu:

\subsubsection{Reduksi data}

Reduksi data merupakan proses pemilihan, pemutusan perhatian pada penyederhanaan, pengabstrakan dan transformasi data kasar yang muncul dari catatan-catatan tertulis di lapangan. Reduksi data berkaitan erat dengan analisis data. Pilihan-pilihan peneliti tentang bagian data mana yang dipilih, data yang dibuang, cerita mana yang sedang berkembang itu merupakan pilihan-pilihan analisis. Reduksi data merupakan bentuk analisis yang menajamkan, menggolongkan, mengarahkan, membuang yang tidak perlu dan mengorganisasi data dengan cara sedemikian rupa hingga kesimpulan akhirnya dapat ditarik dan diverifikasi.Data yang diperoleh dari lapangan jumlahnya cukup banyak meliputi pelaksanaan yaitu (1) Kepala Sekolah, (2) Guru, (3) Siswa SMA Negeri 1 Moga, (4) Ruang Kelas SMA Negeri 1 Moga. Untuk itu perlu dicatat secara teliti dan 
rinci, kemudian dianalisis. Mereduksi data berarti merangkum, memilih hal-hal yang pokok, memfokuskan pada hal-hal yang penting, dicari tema dan polanya. Dengan demikian data yang diperoleh peneliti di SMA Negeri 1 Moga yang telah direduksi memberikan gambaran yang lebih jelas, dan mempermudah peneliti untuk melakukan pengumpulan data selanjutnya dan mencarinya bila diperlukan.

\subsubsection{Sajian data}

Penyajian data merupakan sekumpulan informasi yang terkumpul dan memberikan kemungkinan adanya penarikan kesimpulan dan pengambilan tindakan. Penyajian yang sering digunakan dalam penelitian kualitatif adalah bentuk wacana naratif (penceritaan kronologis) yang merupakan penyederhanaan dari informasi yang banyak jumlahnya ke dalam kesatuan bentuk yang disederhanakan.Setelah data direduksi, maka langkah selanjutnya adalah mendisplay data sesuai kelompok meliputi pelaksanaan yaitu (1) Kepala Sekolah, (2) Guru, (3) Siswa SMA Negeri 1 Moga, (4) Ruang Kelas SMA Negeri 1 Moga. Dengan mendisplay data, maka akan memudahkan untuk memahami apa yang terjadi, merencanakan kerja selanjutnya berdasarkan apa yang telah dipahami tersebut. Pada penelitian di SMA Negeri 1 Moga penyajian data menggunakan uraian singkat agar memudahkan untuk dipahami.

\subsubsection{Penarikan kesimpulan atau verifikasi}

Kegiatan verifikasi merupakan kegiatan yang sangat penting, sebab dari awal pengumpulan data, seorang penganalisis kualitatif harus mampu mencari bendabenda, mencatat keteraturan, pola-pola, konfigurasi yang semua merupakan satu kesatuan yang utuh, barangkali ada keterkaitan alur, sebab akibat preposisi. 
Dibawah ini merupakan skema analisis data kualitatif model interaktif menurut Milles dan Huberman dalam Sumaryanto (2007:23).

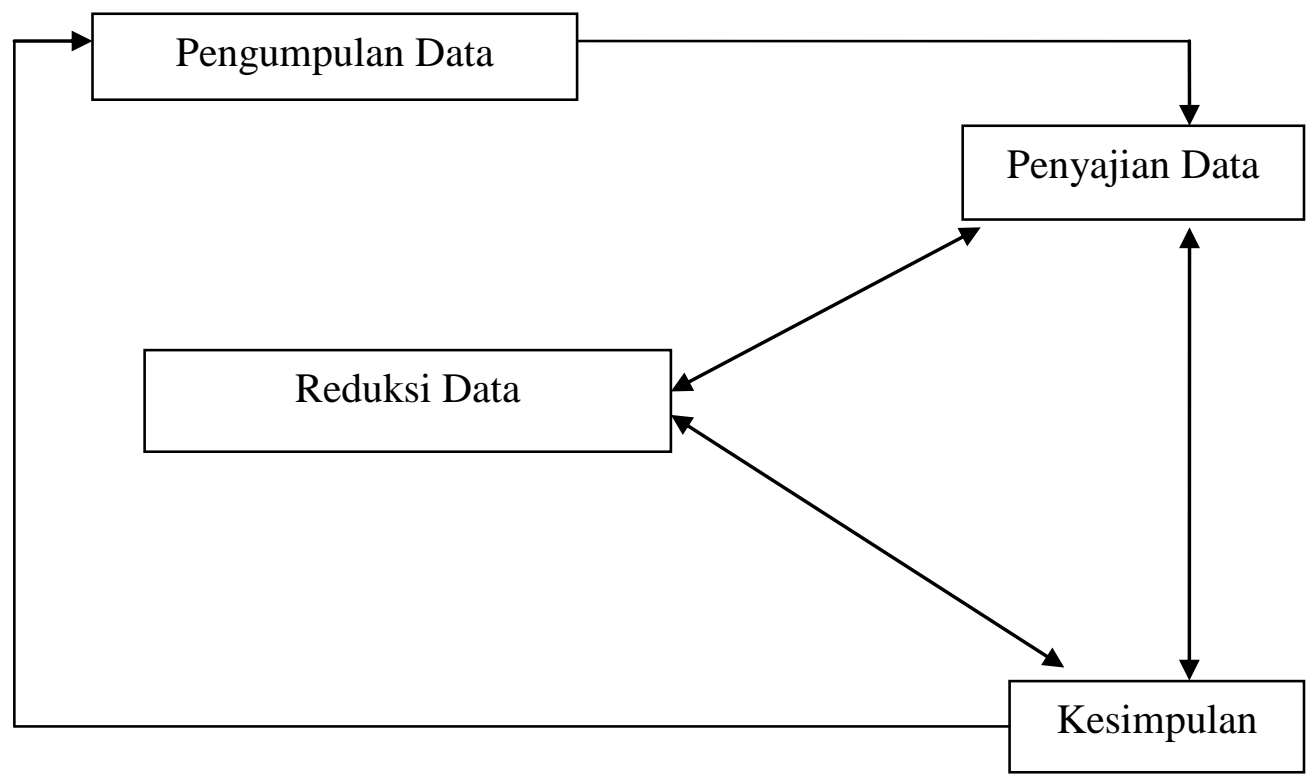

Skema 3.1 Analisis Data Kualitatif

(Milles dan Huberman, 2007:23) 


\section{BAB IV}

\section{HASIL PENELITIAN}

\subsection{Gambaran Umum Lokasi Penelitian}

\subsubsection{Profil SMA Negeri 1 Moga}

SMA Negeri 1 Moga didirikan pada tahun 1999 dengan Nomor Statistik Sekolah (NSS) 301032709029, SK terakhir sekolah tentang pembukaan dan penegerian sekolah No. 425./898./A/2007, tanggal 22 Agustus 2007 dengan luas tanah $13.000 \mathrm{~m} 2$ dan luas bangunan $3.920 \mathrm{~m} 2$. Namun mulai beroperasional pada tahun 1999. SMA Negeri 1 Moga terletak di jalan Camping Sight Desa Banyumudal kecamatan Moga kota Pemalang Jawa Tengah.. Jika dari jalan raya Moga-Pulosari, pertigaan SMP Negeri 1 Moga belok kiri lurus sesudah kantor kelurahan Banyumudal kemudian belok kanan. SMA Negeri 1 Moga bersebelahan dengan kantor PDAM Tirta mudal. Sekitar 100 meter dari SMA Negeri 1 Moga tepat disebelah kanan. Gedung SMA Negeri 1 Moga terletak satu lokasi dengan SD Negeri 5 Banyumudal, sehingga kegiatan proses belajar mengajar cukup ramai. Namun letak gedung SMA Negeri 1 Moga yang bersebelahan dengan sekolah lain tidak membuat proses belajar mengajar menjadi terganggu atau gaduh. Hal ini dikarenakan tekstur tanah dari gedung SMA Negeri 1 Moga yang semakin naik semakin tinggi tekstur tanahnya membuat letak gedung SMA Negeri lumayan jauh dari gangguan yang ada diluar gedung. 


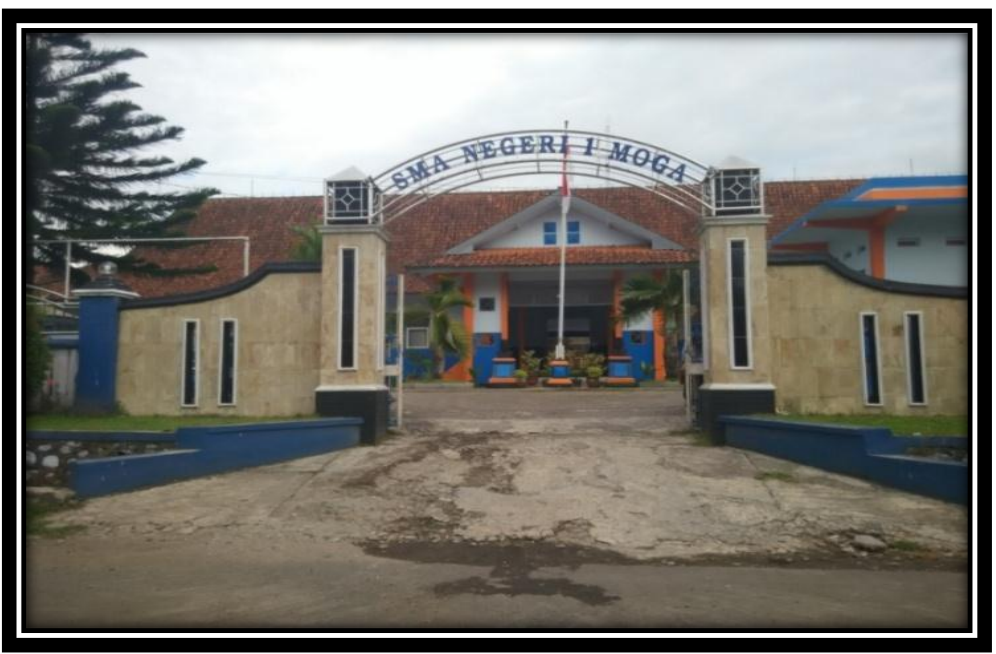

Gambar 4.1 Gedung SMA Negeri 1 Moga (Sumber: foto Diah Puspitasari, April 2017)

Gambar 4.1 diatas adalah gedung SMA Negeri 1 Moga yang terlihat dari halaman depan. Terdapat 27 ruang kelas dan satu ruangan guru, satu ruang staf tata usaha, satu lapangan basket, laboratorium musik dan beberapa sarana pembelajaran lainnya. Sedangkan foto 4.4 adalah ruang laboratorium musik SMA Negeri 1 Moga.

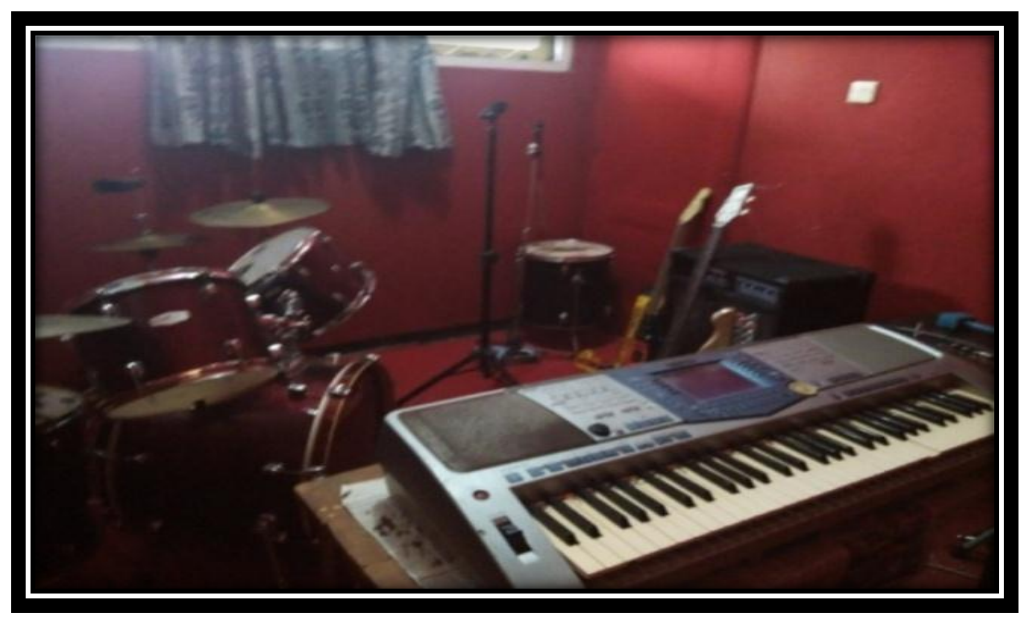

Gambar 4.2 Ruang Laboratorium Musik SMA Negeri 1 Moga (Sumber: foto Diah Puspitasari, April 2017) 


\subsubsection{Visi dan Misi}

\subsubsection{Visi SMA Negeri 1 Moga}

Secara umum visi dan SMA Negeri 1 Moga sebagai berikut :

“ Terwujudnya Generasi yang Kuat Iman dan Taqwa, Disiplin dan Berbudi Pekerti Luhur, Berprestasi dan Berwawasan Lingkungan “.

\subsubsection{Misi SMA Negeri 1 Moga}

Untuk mewujudkan visi, SMA Negeri 1 Moga memiliki misi sebagai berikut :

1. Meningkatkan iman dan taqwa kepada Tuhan YME melalui pelajaran agamadan pelajaran lainnya.

2. Menumbuh kembangkan penghayatan terhadap ajaran, agama yang dianut dan budaya bangsa, sehingga menjadi sumber kearifan dalam berperilaku dan bertindak.

3. Melaksanakan kegiatan belajar mengajar secara efektif dan efisien berdasarkan kurikulum yang berlaku.

4. Meningkatkan prestasi akademik dan non akademik melalui peningkatan mutu dan sarana pembelajaran.

5. Memberikan kesempatan peserta didik seluas-luasnya untuk meningkatkan kemampuan potensi dan bakat seoptimal mungkin melalui kegiatan intra dan ekstrakurikuler.

6. Menujuan yang hendak dicapai ada umbuhkan semangat bersaing yang sehat dalam IMTAQ, IPTEK, Olahraga dan Seni Budaya. 
7. Melaksanakan segala ketentuan yang mengatur operasional sekolah, baik tata tertib kepegawaian maupun kesiswaan.

8. Menanamkan dan aplikasi nilai-nilai budi pekerti dan nilai-nilai luhur bangsa baik di sekolah, di rumah maupun di masyarakat.

9. Menanamkan rasa peduli lingkungan kapanpun dan dimanapun ia berada.

\subsubsection{Keadaan Sekolah}

SMA Negeri 1 Moga merupakansalahsatu Sekolah Menengah Atas berstatuskan negeri yang ada di kelurahan Banyumudal, Kecamatan Moga, Kota Pemalang Jawa Tengah. Lokasisekolahiniberadatepat di antarakantor PDAM Tirta Mudal dan SD Negeri 5 Banyumudal. Kondisi sekolah yang terletak di jalan utama menuju Bumi Perkemahan Camping Sight Sikucing dan jauh dari kendaraan-kendaraan yang melintasi in imembuat suasana kegiatan belajar mengajar menjadi efektif karena siswa bisalebih fokus terhadap pelajaran yang diberikan tanpa harus terganggu dengan suara bising dari kendaraan maupun yang lain.

Peserta didik SMA Negeri 1 Moga pada tahun ajaran 2016/2017 berjumlah 400 siswa. Keseluruhan jumlah siswa tersebut terbagi atas kelompok kelas X(Bahasa, IPA, dan IP), Kelas XI (Bahasa, IPA, dan IPS), kelas XII (Bahasa, IPA, dan IPS). Kelas X berjumlah 397 siswa dengan jumlah siswa Kelas X Bahasa 40 siswa, siswa kelas X IPS 157 siswa, dan siswa kelas X IPA 200 siswa. Sedangkan kelas XI berjumlah 394 siswa, dengan jumlah siswa XI Bahasa38 siswa, siswa kelas XI IPS150 siswa dan siswa kelas XI IPA 206 siswa. Kemudian kelas XII berjumlah 310 siswa dengan jumlah siswa kelas XII Bahasa 39 siswa, 
siswa kelas XII IPS 151 siswa, dan siswa kelas XII IPA 158 siswa. Dalam pelaksanaan pembelajarannya sesuai dengan keputusan propinsi 5 hari kerja (Full Day School) untuk Sekolah Menengah Atas yang berbasis negeri, jadwal masuk pelajaran dimulai pukul 07.30 WIB, waktu istirahat pertama pada pukul 09.30 WIB dan istirahat kedua pada pukul 12.30, sedangkan waktu pulang sekolah pukul 03.30 WIB. SMA Negeri 1 Moga mempunyai laboratorium biologi, laboratorium kimia, laboratorium fisika, laboratorium komputer dan ruang keterampilan/media. Selain itu, ada fasilitas lainnya seperti lapangan basket dan lapangan bermain voli di halaman sekolah, dan lain sebagainya. Semua fasilitas di SMA Negeri 1 Moga digunakan siswa pada saat jam pembelajaran maupun istirahat sekolah.

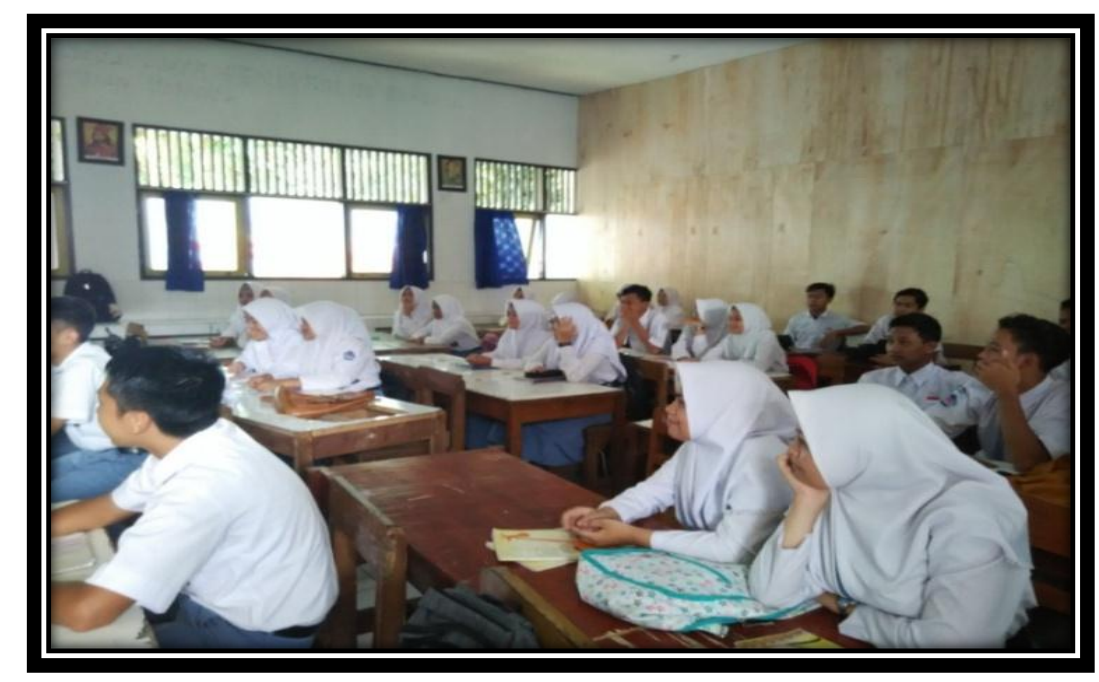

Gambar 4.3 Ruang Kelas SMA Negeri 1 Moga

(Sumber: foto Diah Puspitasari, April 2017)

Gambar 4.3 di atas adalah keadaan di dalam ruang kelas SMA Negeri 1 Moga. Di kelas tersebut siswa mengikuti pembelajaran dengan baik dengan 
menggunakan sarana dan prasarana yang dapat menunjang dalam kegiatan pembelajaran di dalam kelas. Keadaan di dalam kelas dibuat senyaman mungkin agae semua siswa yang ada di dalamnya dapat mengikuti pembelajaran dengan baik.

Guru di SMA Negeri 1 Moga terdiri atas Kepala Sekolah, 42 guru kelas (termasuk guru tidak tetap), dan 17 tenaga administrasi. Untuk wali kelas terdiri atas satu guru.

Skema 4.1 Susunan Organisasi SMA Negeri 1 Moga

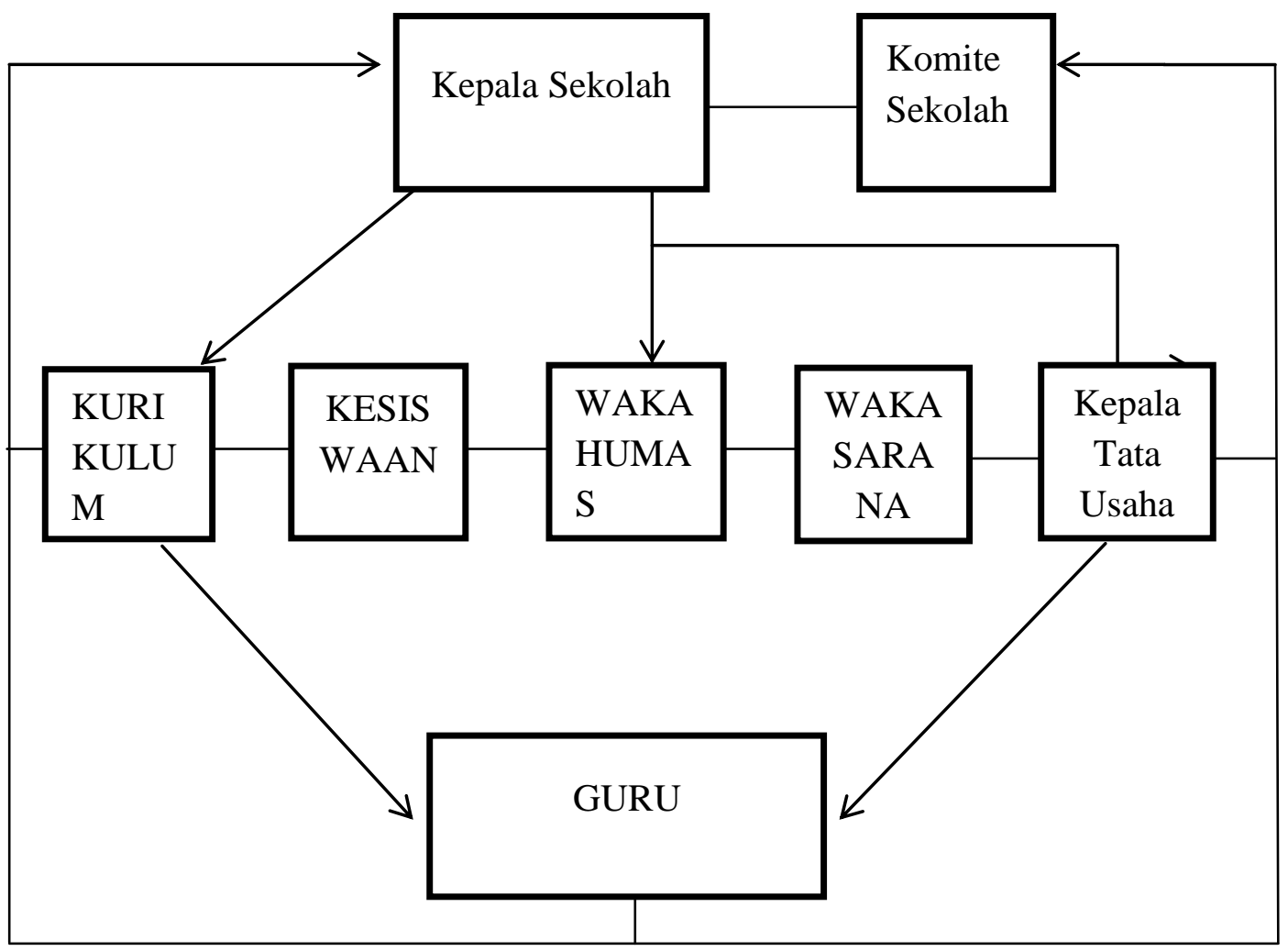

Skema 4.1 diatas menunjukkan susuan organisasi SMA Negeri 1 Moga.

Peran guru pada saat kegiatan pembelajaran musik sangat diperlukan. Meskipun glatar belakang guru bukan dari pendidikan musik, namun guru lain tidak 
dapatmenggantikan guru tersebut karena tidak semua guru mempunyai kemampuan dalam bidang musik seperti yang dimiliki oleh Bapak Erwanto.S.Pd.

\subsubsection{Kegiatan Ekstrakurikuler Sekolah}

Kegiatan ekstrakurikuler merupakan pendidikan di luar mata pelajaran untuk membantu mengembangkan siswa sesuai dengan potensi, bakat dan minat mereka, yang diselenggarakan oleh pelatih atau tenaga pendidik yang berkemampuan serta memiliki ketrampilan khusus.Adapun kegiatan ekstrakurikuler yang dimiliki SMA Negeri 1 Moga yang bertujuan sebagai penunjang bakat dan ketrampilan yang dimiliki masing-masing siswa. Sebab dalam jiwa siswa, bakat yang diasah sejak dini akan meningkatkan kualitas diri siswa tersebut dan jika tidak dikembangkan maka kreativitasnya tidak bisa berkembang bahkan bisa hilang.

Kegiatan ekstrakurikuler merupakan pendidikan di luar mata pelajaran untuk membantu mengembangkan siswa sesuai dengan potensi, bakat dan minat mereka, yang diselenggarakan oleh pelatih atau tenaga pendidik. Ekstrakurikuler di SMA Negeri 1 Moga sangat berkembang. Salah satunya adalah Seni Musik.. Tetapi intensitas pada latihannya tidak menentu, karena pembina dari ekstra

kurikuler tersebut bukan murni dari pendidikan seni musik, jadi hanya beberapa jenis alat musik saja yang bisa di ajarkan. Tetapi jika siswa mempunyai bakat musik bisa dikembangkan melalui ekstrakurikuler tersebut. Hasil dari ektrakurikuler tersebut dipentaskan pada hari tertentu saja. Diantaranya dies Natalis Sekolah, perpisahan sekolah dan hari-hari besar nasional lainnya. Pelatih 
ekstrakurikuler tersebut tidak didatangkan dari luar sekolah, melainkan dari guru SMA Negeri 1 Moga yaitu Bapak Erwanto, S.Pd.

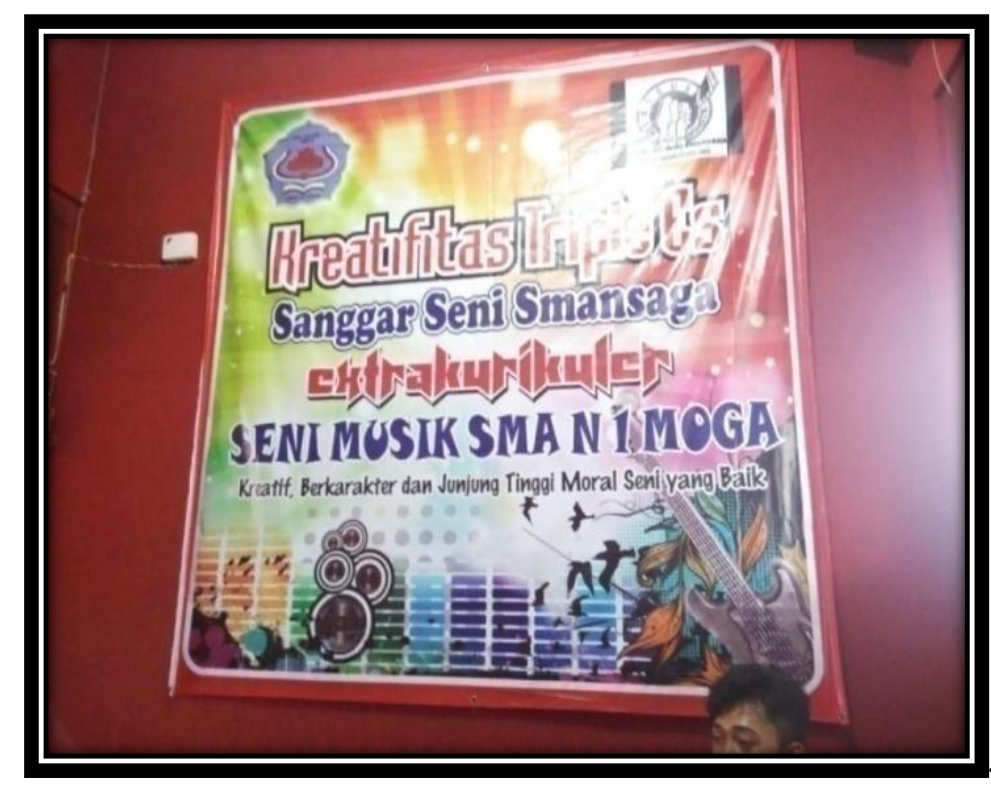

Gambar 4.4 Kegiatan ektrakurikuler Seni Musik SMA Negeri 1 Moga (Sumber: foto Diah Puspitasari, April 2017)

\subsubsection{Prestasi Sekolah}

Prestasi sekolah merupakan hasil belajar dari proses kegiatan belajar mengajar. SMA Negeri 1 Moga pernah mengikuti kegitan lomba kejuaraan baik ditingkat Kecamatan maupun Kabupaten. Lomba-lomba yang pernah diikuti oleh SMA Negeri 1 Moga adalah salah satunya lomba paduan suara di SMA Negeri 1 Pemalang. Selain lomba paduan suara, ada juga lomba-lomba yang pernah diikuti SMA Negeri 1 Moga seperti lomba nyanyi pada acara franscofet.

\subsubsection{Kreativitas Guru SMA Negeri 1 Moga}

Kreativitas guru merupakan istilah yang banyak digunakan, baik di lingkungan sekolah maupun luar sekolah.Pada umumnya orang menghubungkan kreativitas dengan produk-produk kreasi. Dengan kata lainproduk-produk kreasi 
itu merupakan hal yang penting untuk menilai kreativitas. Kreativitas adalah pengalaman mengekspresikan (mengaktualisasikan) identitas individu dalam bentuk terpadu dalam hubungan dengan diri sendiri, dengan alam dan orang lain. Dari situlah sehingga dapat diartikan bahwa guru yang kreatif adalah guru yang mampu mengaktualisasikan dan mengekspresikan secara optimal segala kemampuan yang ia miliki dalam rangka membina dan mendidik anak didik dengan baik

Guru kreatif adalah salah satu faktor yang mempengaruhi kualitas pendidikan. Kualitas pembelajaran dipengaruhi pula oleh sikap guru yang kreatif untuk memilih dan melaksanakan pendekatan dan model pembelajaran. Karena profesi guru menuntut sifat kreatif dan kemauan mengadakan improvisasi. Oleh karena itu guru harus menumbuhkan dan mengembangkan sifat kreatifnya. Proses kreativitas guru dalam pembelajaran drum di SMA Negeri 1 Moga meliputi empat tahapan yaitu: (1) persiapan; (2) inkubasi; (3) iluminasi; dan (4) verifikasi. Kreativitas guru di SMA Negeri 1 Moga yang telah dijabarkan diatas adalah sebagai berikut:

\subsubsection{Guru Mengenalkan Komponen-komponen Alat Musik Drum}

Sesuai dengan Kurikulum yang berlaku materi pembelajaran pada semester I adalah pembelajaran alat musik. Karena guru mengajarkan alat musik drum kepada siswa sehingga perlu adanya pengenalan komponen-komponen drum beserta fungsinya. Dengan pengenalan tersebut sebelum siswa mempelajari bagaimana cara memainkan drum, siswa sudah mengetahui komponen-komponen drum beserta fungsinya. 


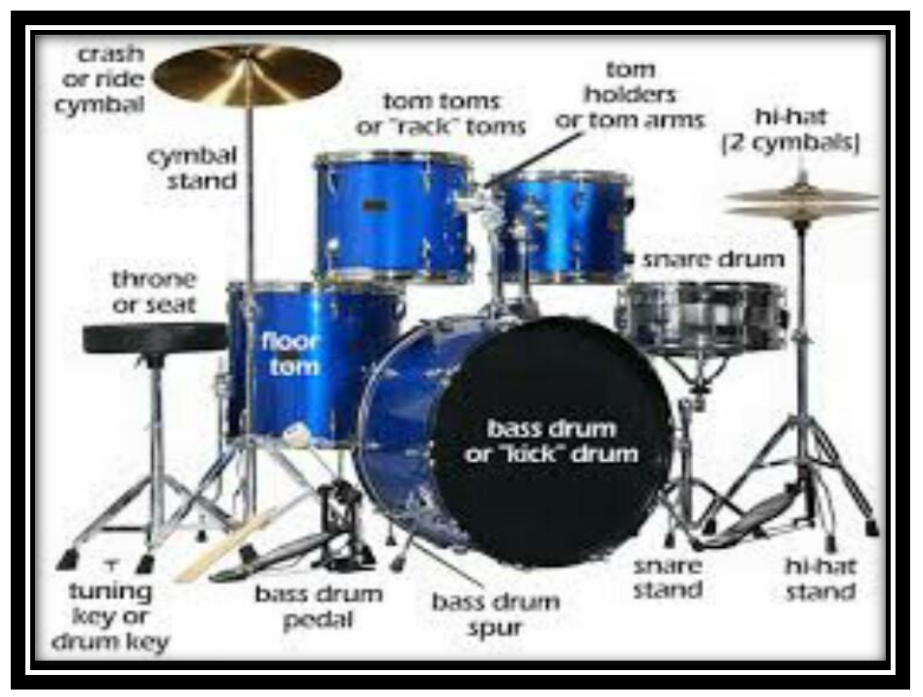

Gambar 4.5 Alat musik drum dan komponen-konponennya (Sumber: foto Diah Puspitasari, April 2017)

\section{Fungsi Komponen Utama Alat Musik Drum}

Fungsi komponen utama alat musik drum adalah sebagai berikut :

\section{Snare}

Snare merupakan unsur yang paling vital dalam drum, karena snare merupakan bagian penentu dalam menentukan ketukan dalam bermain drum. Snare pun terdiri dari berbagai versi ukuran antara 10 hingga 15 derajat. Pada Snare terdapat bagian yang sangat penting yaitu snare wire/stainer yang terdapat dibawah snare. Jika kita memukul sisi atas pada drum, maka stainer yang dirapatkan pada bawah snare akan berinteraksi yang menghasilkan bunyi yang sangat nyaring.

\section{Bass Drum}

Bass Drum adalah bagian dari drum yang merupakan bagian yang sangat vital dari drum. Karena bass drum mempunyai fungsi yang hampir sama dengan snare drum, yaitu sebagai penentu ketukan pada saat kita bermain drum. Bass 
drum biasanya dimainkan oleh kaki kanan kita (standar) atau bisa juga dimainkan oleh kedua kaki kita (tergantung kebutuhan). Dalam memainkan bass drum kita dibantu oleh alat yaitu pedal.

3. Tom-tom

Tom-tom pada drum merupakan kelengkapan pada drum set, dimana drummer dapat lebih leluasa mem-variasikan pukulan. Tom-tom muncul pada decade 30 -an, pada awalnya tidak bisa dituning. Tom-tom terdiri dari bermacammacam ukuran dan bahan yang berbeda, biasanya tom-tom terbuat dari kayu maple atau birch.

\section{Cymbal}

Terdiri dari hihat cymbal, crash cymbal, splash cymbal, china cymbal, dan bell cymbal.

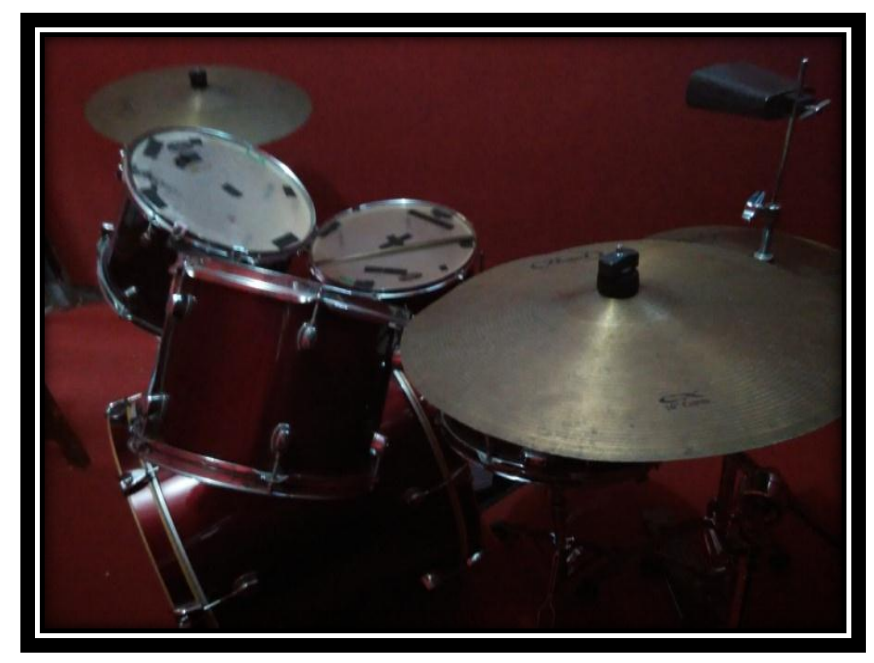

Gambar 4.6 Satu set alat musik drum SMA Negeri 1 Moga

(Dokumentasi : Diah Puspitasari, April 2017 


\subsubsection{Guru Mengajarkan Cara Bermain Alat Musik Drum Secara Virtual}

Guru mengajarkan bagaimana cara bermian drum secara virtual kepada siswanya. Virtual menurut Kamus Besar Bahasa Indonesia (KBBI) adalah tidak nampak, jadi menurut guru pembelajaran drum dilakukan dengan virtualisasi artinya belajar cara bermian drum namun tidak memerlukan alat musik drum sebenarnya. Sebeleum guru menentukan proses pembelajaran drum secara virtual, guru mendapat sumber acuan dari aplikasi games virtual drumming.Virtual drum merupakan simulasi aplikasi drum yang mirip dengan drum aslinya, dengan sejumlah efek dan gambar. Dengan adanya virtual drum saja belum cukup pemula untuk memahami materi drum karenanya virtual drum akan mengajarkan pemula ke hal praktek saja dan tidak mengajarkan materi oleh sebab itu, dibuatlah media pembelajaran alat musik drum yang bermaterikan tentang pengenalan komponen drum, teknik memukul, notasi, ritme dan lainnya.

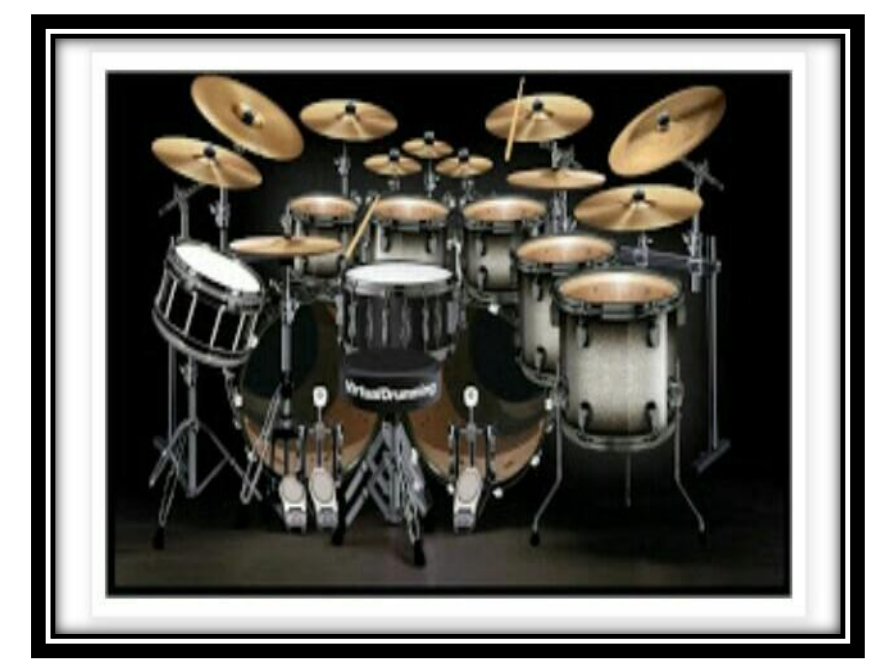

Gambar 4.7 Aplikasi virtual drum sebagai acuan guru (Dokumentasi: Diah Puspitasari, April 2017) 
Guru menggunakan virtual drum lesson, karena pada virtual drum lesson ini guru dapat menjelaskan kepada siswa bagaimana cara belajar dasar-dasar teori bermain drum. Menurut guru ini sangat cocok bagi pemula yang sedang belajar bermain drum.

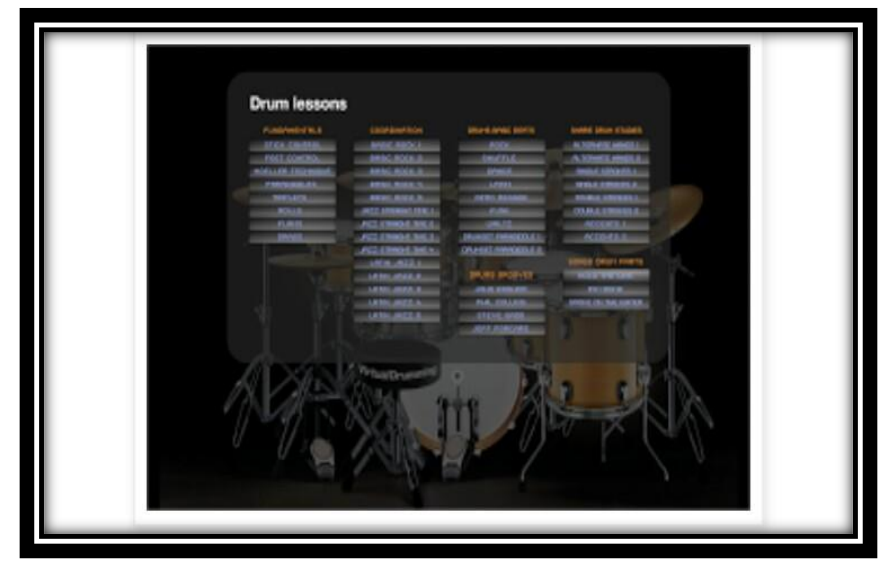

Gambar 4.8 Virtual Drum Lessons yang digunakan oleh guru sebagai acuan dalam pembelajaran drum.

(Dokumentasi: Diah Puspitasari, April 2017)

Guru hanya melihat bagaimana cara memainkan virtual Drum lessons, setelah guru memahami bagaimana cara memainkannya kemudian guru menyusun strategi bagaimana cara menyampaikan materi virtual drum kepada siswa dengan menggunakan virtual drum lessons. Setelah menyusun strategi dan metode pembelajaran virtual drum. Ada beberapa langkah-langkah yang guru dilakukan dalam mengajarkan pembelajaran drum secara virtual, diantaranya:

1. Menentukan Tema Pembelajaran Drum secara Virtual

Tema merupakan ide-ide pokok yang mempunyai unsur-unsur musikal utama pada sebuah komposisi yang masih harus dikembangkan lagi, sehingga terbentuknya sebuah komposisi secara utuh. Dalam sebuah karya bisa mempunyai lebih dari satu tema pokok dimana masing-masing akan mengalami 
pengembangan.Berikut adalah cara guru SMA Negeri 1 Moga untuk menentukan tema dalam pembelajaran drum secara virtual :

1.1 Apresiasi musik yang sudah ada

Apresiasi musikadalah mengajarkan orang orang apa maksud mendengarkan musik dan mengapresiasikan berbagai jenis musik. Sebelum guru menentukan tema yang akan dipakai dalam membuat pola, guru mencari dan melihat bagaimana cara memainkan aplikasi virtual drum terlebih dahulu, dengan menggunakan media elektronik seperti HP (Handphone)yang mempunyai kapasitas android yang berupa games virtual drumming sebagai media apresiasi untuk menentukan pola dalam pembelajaran virtual drum tanpa memperkenalkan aplikasi virtual drum kepada siswanya. Dari beberapa aplikasi virtual drum yang dimainkan, guru dapat menentukan pola dalam pembelajaran virtual drum sehingga siswa mudah dalam mengikuti pembelajaran tersebut.

1.2 Menentukan ide atau gagasan

Setelah guru mengapresiasi musik dengan melihat bagaimana cara memainkan aplikasi virtual drum tersebut, guru dapat menentukan ide atau gagasan untuk membuat teknik baru dalam pembelajaran drum. Ide atau gagasan yang didapat oleh guru SMA Negeri 1 Moga bertema pembelajaran drum secara virtual. Guru memilih tema pembelajaran drum secara virtual supaya siswa dapat memainkan alat musik drum tanpa harus menggunakan alat musik drum sebenranya. Tema pembelajaran drum secara virtual dipilih oleh guru selain untuk memberi pengetahuan tentang bagaimana cara memainkan drum dengan teknik yang paling sederhana tanpa harus menggunakan alat musik drum sebenarnya. 
2. Membuat pola-pola sederhana dalam pembelajaran drum secara virtual

Pola merupakan ringkasan paling sederhana dari suatu objek yang berfungsi menjelaskan lebih singkat namun dapat dimengerti oleh pembacanya. Dalam mengekspresikan pengalamannya, melakukan permainan kata-kata dan bahasa untuk menciptakan daya tarik dan kekhasan terhadap pola sederhana dalam pembelajaran secara virtual dengan cara:

\subsection{Menyesuaikan tema}

Guru menyusun pola-pola sederhana dalam pembelajaran drum sesuai dengan tema yang sudah ditentukan. Tema yang sudah ditentukan oleh guru yaitu pembelajaran drum secara virtual. Guru menentukan birama 4/4 dalam pembelajaran drum secara virtual yang akan disampaikan kepada siswanya.

2.2 Menentukan alur pembelajaran

Sesudah guru menentukan biarama $4 / 4$ dalam pembelajaran drum secara virtula tersebut, kemudian guru menentukan alurpembelajaran. Alur pembelajaran yang guru buat adalah membuat 2 pola sederhana birama 4/4 yaitu: (1) pola sau ketukan; dan (2) pola 1/2 ketukan:

2.2.1 Pola dengan satu ketukan birama 4/4

2.2.2 pola dengan penambahan keterangan $n$ yang nilainya masing-masing $1 / 2$ ketuk dengan birama $4 / 4$

2.3 Membuat langkah-langkah pembelajaran

Langkah-langkah adalah tahapan-tahapan terstruktur yang berfungsi untuk menyusun sesuatu secara sistematis dan mudah dimengerti. Sedangkan Pembelajaran adalah interaksi guru dan siswa yang melakukan proses belajat yang 
didalamnya terdapat kegiatan operasi formal, prediksi, eksperimentasi, dan eksplanasi serta membelajarkan siswa dalam belajar bagaimana belajar memperoleh dan memproses pengetahuan, keterampilan, dan sikap. Langkahlangakah pembelajaran yang guru buat sangat sederhana. Ada dua tahap guru membuat langkah pembelajaran yaitu sebagai berikut:

1. Kerangka dasar pola sederhana pembelajaran drum secara virtual

1.1 Pola dengan satu ketukan birama 4/4

$\begin{array}{lllll}4 / 4 & 1 & 2 & 3 & 4\end{array}$

Keterangan :

1 : tangan kanan (cymbal drum) dan kaki kanan (bass pedal drum)

2 : tangan kanan (cymbal drum) dan tangan kiri (snare drum)

3 : tangan kanan (cymbal drum) dan kaki kanan (bass pedal drum)

4 : tangan kanan (cymbal drum) dan tangan kiri (snare drum)

1.2 Pola dengan $1 / 2$ ketukan birama $4 / 4$

$\begin{array}{llllllllll}4 / 4 & 1 & n & 2 & n & 3 & n & 4 & n\end{array}$

Keterangan :

1 : tangan kanan (cymbal drum) dan kaki kanan (bass drum pedal)

$\mathrm{n}$ : tangan kanan (cymbal drum)

2 : tangan kanan (cymbal drum) dan tangan kiri (snare drum)

$\mathrm{n}$ : tangan kanan (cymbal drum) 
3 : tangan kanan (cymbal drum) dan kaki kanan (bass drum pedal)

$\mathrm{n}$ : tangan kanan (cymbal drum)

4 : tangan kanan (cymbal drum) dan tangan kiri (snare drum)

$\mathrm{n}$ : tangan kanan (cymbal drum)

2.4 Menyusun secara lengkap langkah-langkah pembelajaran drum secara virtual Menyusun adalah menempatkan atau mengurutkan sesuatu menjadi lebih sistematis. Berikut susunan pola sederhana dalam pembelajaran drum secara virtual:

2.4.1 Pola dengan satu ketukan birama $4 / 4$

$\begin{array}{lllll}4 / 4 & 1 & 2 & 3 & 4\end{array}$

Keterangan :

1 : tangan kanan (cymbal drum) dan kaki kanan (bass pedal drum)

2 : tangan kanan (cymbal drum) dan tangan kiri (snare drum)

3 : tangan kanan (cymbal drum) dan kaki kanan (bass pedal drum)

4 : tangan kanan (cymbal drum) dan tangan kiri (snare drum)

\subsubsection{Langkah-langkah :}

1. Menentukan birama 4/4 dengan pola satu ketukan.

2. Kemudian guru menuliskan pola dengan angka 1234 seperti keterangan di atas. 
3. Guru mengajarkan gerakan dengan menggunakan tangan kanan (cymbal drum) dan kaki kanan (bass pedal drum) pada ketukan pertama atau pada pola dengan keterangan angka 1 .

4. Kemudian setelah pola pada gerakan angka 1, guru mengajarkan gerakan tangan kanan (cymbal drum) dan tangan kiri (snare drum) pada pola ketukan kedua dengan angka 2.

5. Pada pola ketukan ke 3 sama dengan pola ketukan yang pertama (pola keterangan angka 1) hanya dilakukan berulang-ulang dengan keterangan tangan kanan (cymbal drum) dan kaki kanan (bass pedal drum).

6. Kemudian pola ketukan ke 4 juga sama halnya dengan pola ketukan kedua (pola keterangan angka 2), karena hanya dilakukan berulang-ulang dengan keterangan tangan kanan (cymbal drum) dan tangan kiri (snare drum).

7. Guru meminta siswa mengikuti gerakan yang diajarkan kepada siswa dari pola ketukan 1 sampai dengan 4 dengan masing-masing keterangan yang sudah disampaikan.

8. Siswa mempraktikkan gerakan yang diajarkan oleh guru tersebut dan dilakukan berulang-ulang dengan tempo yang sangat sederhana sampai siswa dianggap mampu. 


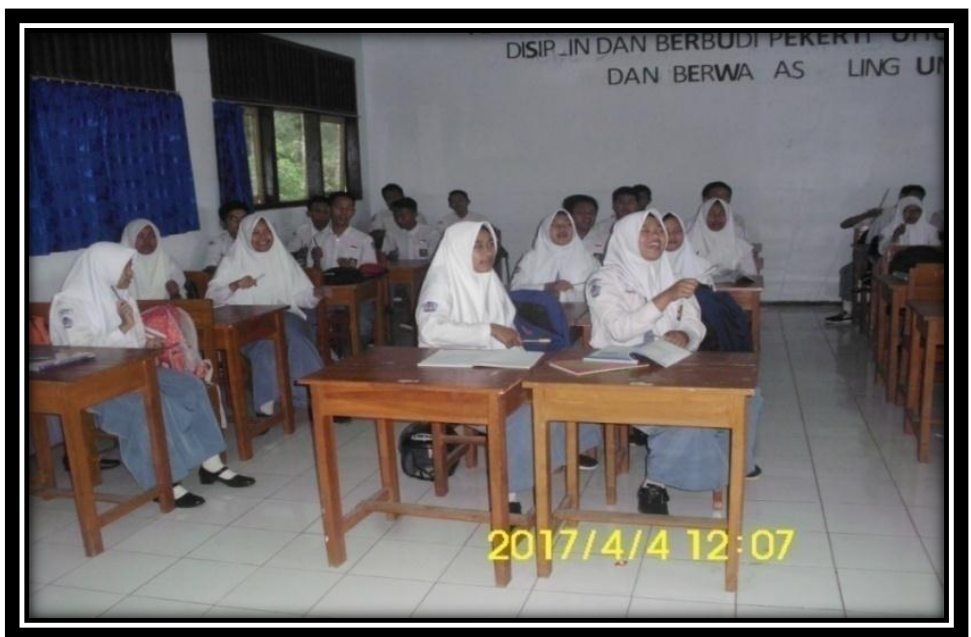

Gambar 4.9 siswa sedang mempraktikkan pola satu ketukan (Dokumentasi : Diah Puspitasari, April 2017)

2.4.2 pola dengan penambahan keterangan " $n$ " yang nilainya masing-masing $1 / 2$ ketuk dengan birama $4 / 4$

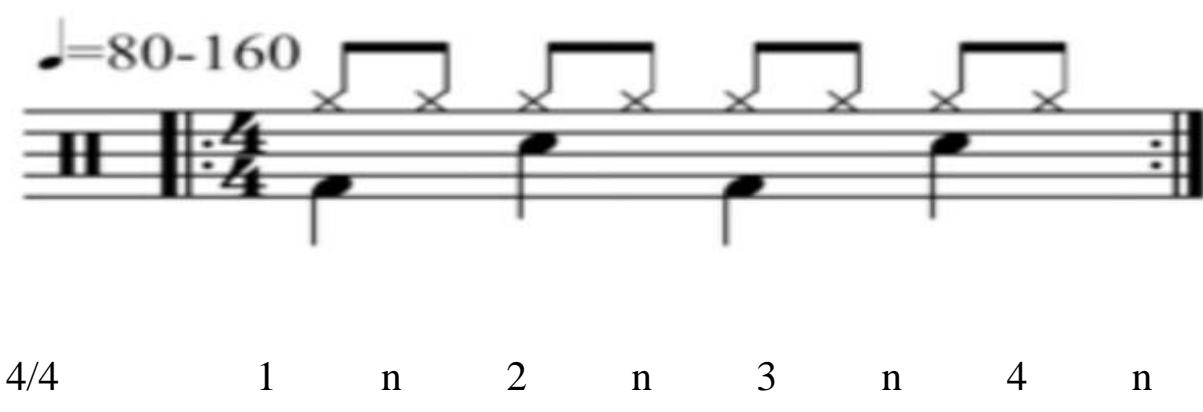

Keterangan :

1 : tangan kanan (cymbal drum) dan kaki kanan (bass drum pedal)

$\mathrm{n}$ : tangan kanan (cymbal drum)

2 : tangan kanan (cymbal drum) dan tangan kiri (snare drum)

$\mathrm{n}$ : tangan kanan (cymbal drum) 
3 : tangan kanan (cymbal drum) dan kaki kanan (bass drum pedal)

$\mathrm{n}$ : tangan kanan (cymbal drum)

4 : tangan kanan (cymbal drum) dan tangan kiri (snare drum)

$\mathrm{n}$ : tangan kanan (cymbal drum)

\subsubsection{Langkah-langkah :}

1. Menentukan birama $4 / 4$ dengan pola $1 / 2$ ketukan.

2. Kemudian guru menuliskan pola dengan angka 1 n 2 n 3 n 4 n seperti keterangan di atas.

3. Guru mengajarkan gerakan dengan menggunakan tangan kanan (cymbal drum) dan kaki kanan (bass pedal drum) pada ketukan pertama dengan nilai 1/2 ketukan atau pada pola dengan keterangan angka 1.

4. Kemudian guru mengajarkan pola " $n$ " dengan keterangan tangan kanan (cymbal drum) dengan nilai ketukan 1/2 ketukan.

5. guru mengajarkan gerakan tangan kanan (cymbal drum) dan tangan kiri (snare drum) pada pola ketukan kedua dengan angka 2 dengan nilai 1/2 ketukan.

6. Kemudian guru mengajarkan pola n dengan keterangan tangan kanan (cymbal drum) dengan nilai ketukan $1 / 2$ ketukan.

7. Lakukan gerakan pola dengan keterangan angka 3 sama dengan pola keterangan angka 1 yaitu tangan kanan (cymbal drum) dan kaki kanan (bass pedal drum) dengan nilai $1 \frac{1}{2}$ ketukan. 
8. Kemudian guru mengajarkan pola $\mathrm{n}$ dengan keterangan tangan kanan (cymbal drum) dengan nilai ketukan $1 / 2$ ketukan.

9. Lakukan gerakan pola dengan keterangan angka 4 sama denga pola keterangan angka 2 yaitu tangan kanan (cymbal drum) dan tangan kiri (snare drum) dengan nilai $1 / 2$ ketukan.

10. Guru meminta siswa mengikuti gerakan yang diajarkan kepada siswa dari pola ketukan 1 n 2 n 3 n 4 n dengan masing-masing keterangan yang sudah disampaikan.

11. Siswa mempraktikkan gerakan yang diajarkan oleh guru tersebut dan dilakukan berulang-ulang dengan tempo yang sangat sederhana sampai siswa dianggap mampu.

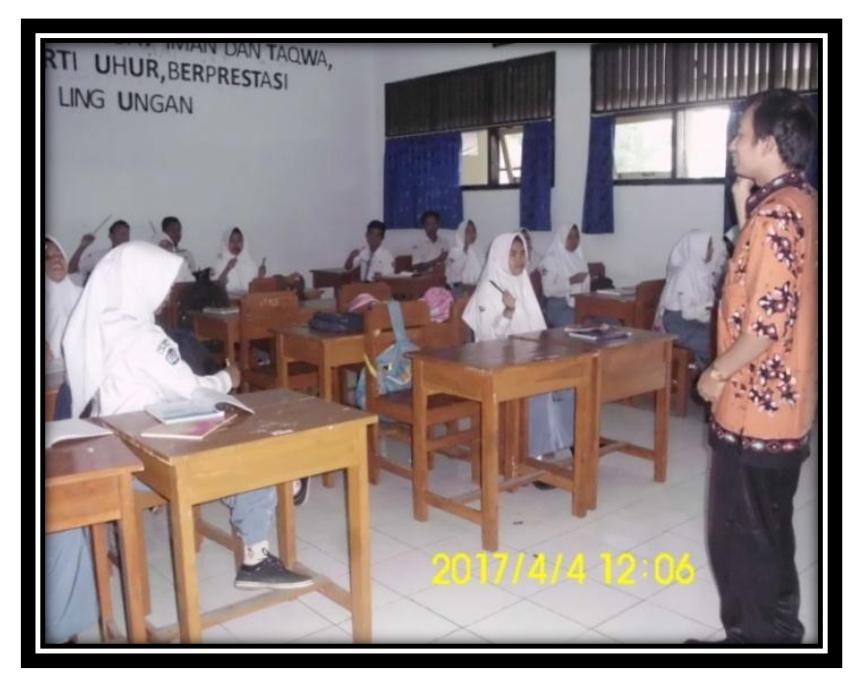

Gambar 4.10 Gurumengajarkan pola 1/2 ketukan pembelajaran drum (Sumber: foto Diah Puspitasari, April 2017)

Setelah guru mengajarkan pembelajaran drum dengan menggunakan pola satu ketukan dan 1/2 ketukan dengan keterangan tangan kanan (cymbal drum), kaki kanan (bass pedal drum), dan tangan kiri (snare drum). Kemudian jika siswa 
sudah cukup mampu untuk memahami dan bisa mempraktikkan, guru mempraktikkan gerakan tersebut ke alat musik drum yang sebenarnya. Kemudian siswa satu per satu maju untuk mempraktikkan ke alat musik drum yang sebenarnya hingga siswa dianggap mampu memainkan kedua pola tersebut sesuai dengan yang telah diajarkan oleh guru.

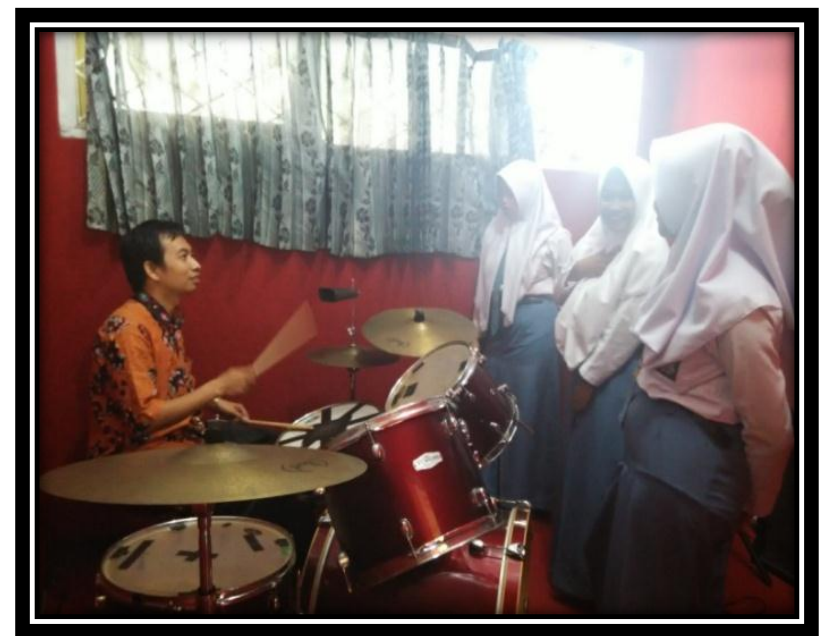

Gambar 4.11 Guru mempraktikkan pembelajaran drum di alat musik drum yang sebenarnya (Sumber: foto Diah Puspitasari, April 2017)

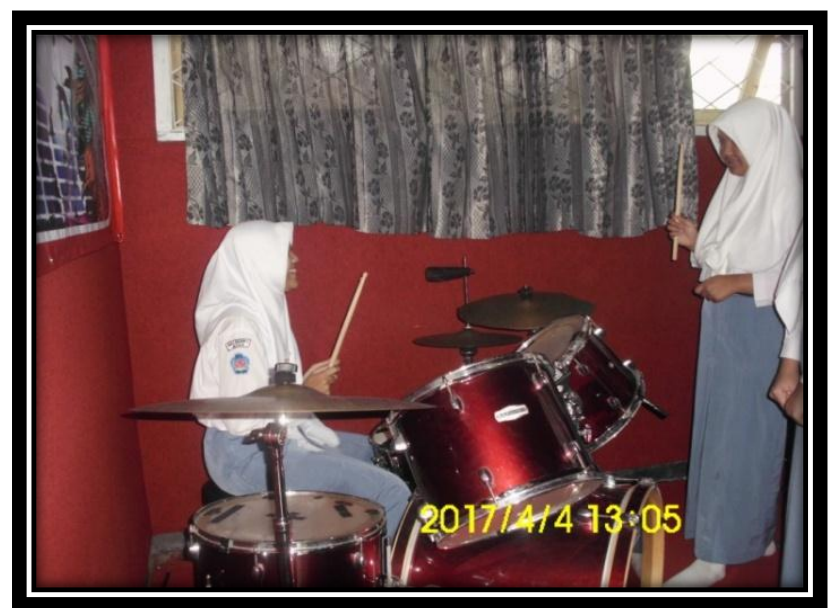

Gambar 4.12 Siswa mempraktikkan pembelajaran drum (Sumber: foto Diah Puspitasari, April 2017) 


\subsubsection{Guru mengajarkan pola ritmis sederhana kepada siswa}

Ritme atau Irama adalah variasi horizontal dan aksen dari suatu suara yang teratur. Ritme terbentuk dari suara dan diam. Suara dan diam tersebut digabungkan untuk membentuk pola suara yang berulang untuk membuat ritme. Ritme memiliki tempo yang teratur, namun dapat memiliki bermacam-macam jenis. Beberapa ketukan dapat lebih kuat, lebih lama, lebih pendek, atau lebih pelan dari lainnya. Dalam sebuah musik, seorang komposer dapat menggunakan banyak ritme berbeda.

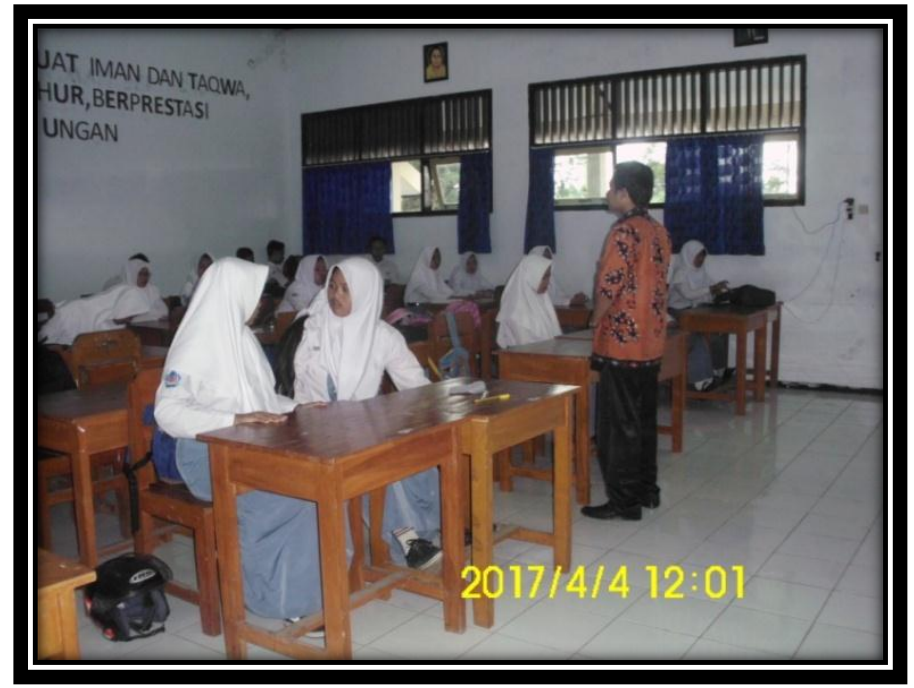

Gambar 4.13 Guru pada Saat Mengajar Pola Ritmis (Sumber: Foto Diah Puspitasari, April 2017 )

Gambar 4.13 menunjukkan bahwa guru sedang mengajarkan tentang pola ritmis sederhana kepada siswa. Guru menggunakan metode demonstrasi dan metode drill.Guru melakukan demonstrasi dengan mencontohkan secara konkret cara memainkan alat musik yang akan dimainkan kepada siswa kemudian siswa menirukan. Selanjutnya guru melakukan metode drill yaitu pengulangan secara terus menerus agar siswa memiliki ketangkasan atau keterampilan dari yang 
diajarakan oleh pelatih. Kedua metode ini dianggap guru cukup bagus untuk melakukan pembelajaran pada siswa SMA Negeri 1 Moga sebelum memainkan alat musik drum. Pembelajaran pola ritmis sederhana,guru dituntut untuk bisa menyampaikan materi secara baik terhadap siswa. Biasanya guru menggunakan snare drum untuk memberi contoh kepada siswa. Berikut salah satu contoh hasil kreativitas pola ritmis sederhana yang diajarkan oleh guru di SMA Negeri 1 Moga:

Contoh pola ritmis:

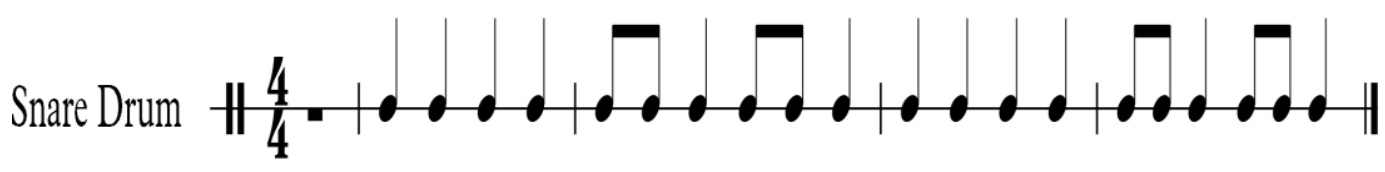
Ka Ki Ka Ki Ka Ki Ka Ka Ki Ka

$$
\begin{aligned}
& \text { Ka }=\text { Tangan Kanan } \\
& \mathbf{K i}=\text { Tangan Kiri }
\end{aligned}
$$

Gambar 4.14 Gambar Pola Ritmis yang dibuat oleh guru

Gambar 4.14 merupakan pola ketukan menggunakan birama 4/4 disetiap barnya. Pada bar pertama dan kedua pola ritmisnya berbeda namun mengalami pengulangan pada bar ketiga dan keempat. Pola ritmis bar pertama sama dengan bar ketiga dan pola ritmis bar kedua sama dengan bar keempat. Tempo yang diajarkan pada pola ritmis diatas dibuat lambat, karena keterbatasan kemampuan guru. Berdasarkan keterangan pada gambar 4.14, "Ka” berarti pukulan stik pada snare drum dilakukan oleh tangan kanan, sedangkan "Ki" berarti pukulan stik pada snare drum dilakukan oleh tangan kiri. 


\subsection{Faktor Pendukung dan Faktor Penghambat}

\subsubsection{Faktor Pendukung}

Seorang guru dalam melaksanakan pembelajaran seni musik harus mempunyai faktor pendukung yang menunjang kreativitas sehingga dapat mendorong keberhasilan dan kesuksesan dalam pembelajaran. Seperti guru di SMA Negeri 1 Moga dalam melakukan pembelajaran drum, juga mempunyai faktor pendukung dalam menunjang kreativitas yang dilihat dari faktor internal dan eksternal.

\subsubsection{Faktor Internal}

Faktor internal, yaitu faktor yang berasal dari dalam individu yang dapat mempengaruhi kreativitas, berikut faktor internal yang terdapat pada faktor pendukung kreativitas guru:

\subsection{Refrensi buku}

Seorang guru sebelum melaksanakan kegiatan belajar mengajar harus mampu mengusai materi yang akan diajarkan, sehingga siswa dapat memahami apa yang telah diajarkan oleh guru. Oleh karena itu, guru di SMA Negeri 1 Moga selalu membaca buku tentang musik untuk meningkatkan kreativitasnya, karena mereka mempunyai pengetahuan tentang musik yang belum memadai. (wawancara dengan Erwanto, S.Pd, 2017).

\subsection{Sarana dan Prasarana}

Sarana dan prasarana sangat penting dalam dunia pendidikan karena sebagai alat penggerak suatu pendidikan. Sarana dan prasarana pendidikan dapat berguna untuk menunjang penyelenggaraan proses belajar mengajar, baik secara langsung 
maupun tidak langsung dalam suatu lembaga dalam rangka mencapai tujuan pendidikan. Prasarana dan sarana pendidikan adalah salah satu sumber daya yang menjadi tolok ukur mutu sekolah dan perlu peningkatan terus menerus seiring dengan perkembangan ilmu pengetahuan dan teknologi yang cukup canggih.

Sarana dan prasarana dalam pembelajaran di SMA Negeri 1 Moga sangat penting untuk menunjang guru dalam melakukan pembalajaran yang kreatif. Di SMA Negeri 1 Moga juga mempunyai sarana dan prasarana yang cukup memadai untuk pembelajaran virtual drum, seperti satu set alat musikdrum, gitar, keyboard, bass gitar, dan satu set alat musik gamelan.

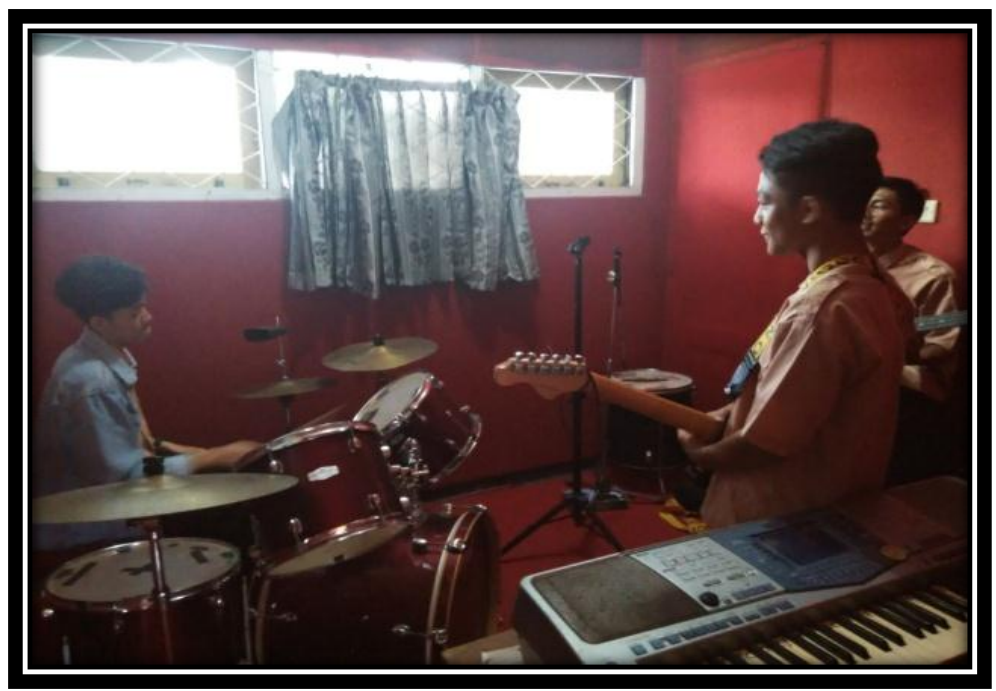

Gambar 4.15 siswa sedang memainkan alat musik (Dokumentasi: Diah Puspitasari, Mei 2017)

Gambar 4.15 beberapa siswa yang sedang mamainkan satu setalatmusik band (gitar, bass gitar, keyboard, dan drum)yang merupakan salah satu contoh sarana dan prasarana pembelajaran untuk siswa. Selain alat musik band, SMA Negeri 1 Moga memiliki satu set alat musik gamelan. Alat musik drum ini 
digunakan guru untuk mengajar pembelajaran virtual drum kepadasiswa. Maka dari itu alat musik drum ini menjadi faktor pendukung sarana dan prasarana di sekolah

\subsection{Keaktifan siswa}

Peranan siswa sangat penting untuk mendukung kreativitas guru di sekolah. Secara umum, berhasil tidaknya pendidikan seorang siswa biasanya dihubungkan dengan keseriusan dan keyakinan pribadi pada saat proses belajar mengajar di kelas. Setiap kegiatan pembelajaran di SMA Negeri 1 Moga, guru selalu memberikan pembelajaran kepada siswa dengan metode-metode yang membuat siswa menarik, sehingga siswa akan menjadi lebih semangat dalam mengikuti kegiatan belajar mengajar di SMA Negeri 1 Moga.

Gambar 4.15 merupakan kegiatan siswa yang sedang mengikuti kegiatan belajar mengajar di kelas. Para. Para siswa dituntut agar bisa mengkuti pembelajaran dengan baik, sehingga materi yang disampaikan oleh guru dapat dimengerti oleh siswa tersebut. Dangan kegiatan belajar mengajar antara guru dan siswa inilah komunikasi yang baik akan terjalin sehingga kesulitan siswa dalam kegiatan belajar mengajar bisa terselesaikan oleh guru maupun siswa tersebut. Selain itu siswa menjadi faktor pendukung untuk menunjang kreativitas guru, karena dengan adanya komunikasi yang baik antara siswa dengan guru pada saat kegiatan belajar mengajar di kelas bisa menjadi semangat untuk para siswa dalam mengikuti kegiatan pembelajaran. 


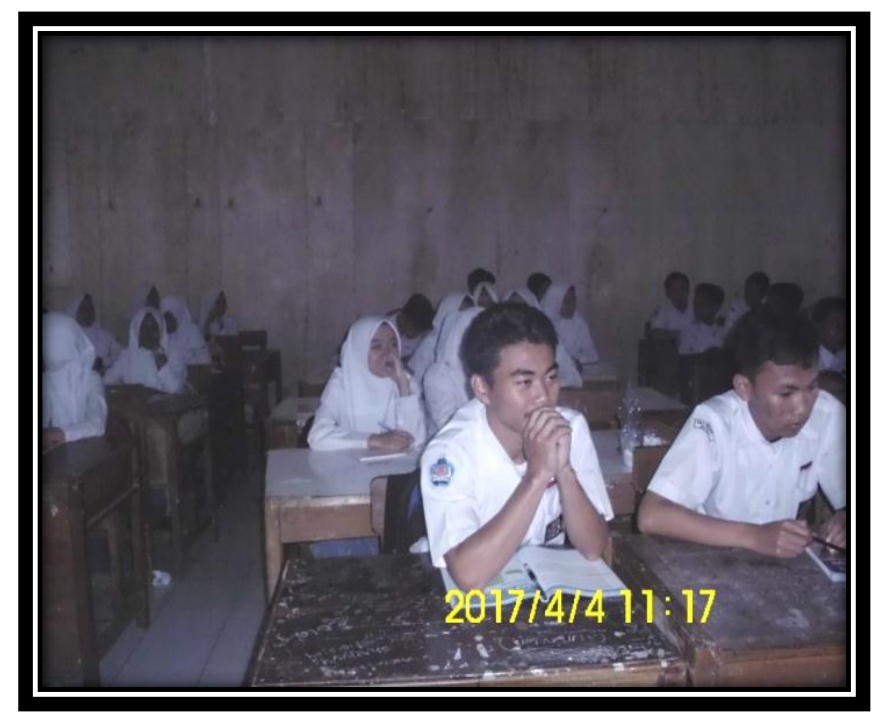

Gambar 4.16 Siswa sedang mengikuti pembelajaran drum di kelas (Dokumentasi : Diah Puspitasari, April 2017)

\subsubsection{Faktor eksternal}

Faktor eksternal (lingkungan) yang dapat mempengaruhi kreativitas individu adalah lingkungan kebudayaan yang mengandung keamanan dan kebebasan psikologis. Peran kondisi lingkungan mencakup lingkungan dalam arti kata luas yaitu masyarakat dan kebudayaan.

Proses belajar mengajar memerlukan ruang dan lingkungan pendukung yang dapat membantu siswa dan guru agar dapat berkonsentrasi dalam belajar. Jika para siswa belajar dalam kondisi menyenangkan dengan lingkungan kelas yang bersih, siswa akan dapat belajar dengan nyaman sehingga proses belajar mengajar akan lebih efektif. Kondisi lingkungan di SMA Negeri 1 Moga sangat bersih dan nyaman, karena letaknya yang jauh dari jalan raya yang dipenuhi dengan kendaraan, serta jauh dari pusat keramaian. Hal ini sangat membantu guru dalam mengembangkan kreativitas belajar khususnya dalam pembelajaran seni musik. 


\subsubsection{Faktor Penghambat}

Selain faktor pendukung, guru juga mempunyai faktor penghambat dalam kegiatan belajar mengajar. Faktor penghambat kreativitas guru di SMA Negeri 1 Moga mempunyai faktor eksternal. Dari hasil wawancara dengan Bapak Erwanto, S.Pd, faktor penghambat kreativitas guru dalam pembelajaran seni musik, yaitu:

\subsubsection{Keterbatasan dana}

Dana sangat berpengaruh dalam kelancaran kegiatan sekolah. Hal ini dilakukan untuk membantu kelancaran kegiatan belajar mengajar ataupun untuk membantu melengkapi sarana sekolah. Alokasi dana yang sudah disediakan oleh Pemerintah baik itu DIKNAS ataupun instansi lainnya bisa kita serap dan kita manfaatkan untuk membantu melengkapi baik itu sarana dan prasarana sekolah. Memang yang diperlukan adalah keaktifan penyelenggara sekolah untuk mendapatkan informasi bantuan sekolah. Oleh sebab itu keterbatasan dana menghambat kreativitas guru SMA Negeri 1 Moga ketika mengaplikasikan ilmu yang guru miliki karena ketersediaan dana tidak dapat membeli alat-alat musik yang memadai. Karena keterbatasan dana di sekolah, alat musik yang dipakai tidak sebaik apa yang dimiliki sekolah lain.

\subsubsection{Keterbatasan kemampuan guru}

Guru merupakan jabatan profesi yang memerlukan keahlian khusus sebagai guru. Dalam pelaksanaanya, guru dituntut memiliki berbagai keterampilan atau kreativitas mengajar, strategi belajar mengajar yang tepat, dan kemampuan melaksanakan evaluasi yang baik. Dengan wawasan yang luas diharapkan guru mampu memperhitungkan berbagai kemungkinan yang akan terjadi dengan 
pertimbangan kondisi sekarang dan pengalaman masa lalu. Tujuan ini adalah agar guru dapat memahami bahwa dalam melaksanakan fungsi dan perannya merupakan fasilitator pendidikan, guru diharapkan mempunyai kemampuan dan kreativitas dalam menjalankan kegiatan mengajar sebagai transforming sciencekepada siswa sebagai penerima dan pengembang ilmu yang telah diberikan oleh guru selama kegiatan pengajaran berlangsung di dalam kelas.

Namun seorang guru juga mempunyai keterbatasan dalam mengajar.Keterbatasanpengetahuan guru terutama masalah pengelolaan dan pendekatan pengelolaan, baik yang sifatnya teoritis maupun pengalaman praktis, sudah tentu akan mengahambat perwujudan pengelolaan kelas dengan sebaikbaiknya. Oleh karenaitu, pengetahuan gurutentang pengelolaan kelas sangat diperlukan. Seperti halnya guru di SMA Negeri 1 Moga yang mempunyai kemampuan mengajar musik yang sangat minim. Karena latar belakang guru tersebut bukan dari pendidikan seni musik, guru SMA Negeri 1 Moga tidak bisa mengajarkan musik secara maksimal. Contohnya guru di SMA Negeri 1 Moga tidak bisa membaca notasi balok, tidak bisa memainkan alat musik tradisional ( gamelan ). Karena minimnya kemampuan guru di SMA Negeri 1 Moga, guru tersebut hanya bisa memainkan sebagian besar alat musik modern seperti gitar, drum, dan keyboard (itupun tidak menggunakan teknik yang sebenarnya) serta guru bisa mengajarkan pola ritmis sederhana dan lagu-lagu yang sederhana.

\subsubsection{Keterbatasan media pembelajaran}

Secara tidak langsung media pembelajaran yang ada di sekolah menjadi bagian terpenting yang harus diadakan keberadaannya.Kualitas sekolah juga dapat 
dilihat dari lengkapnya media pembelajaran yang dimiliki sekolah. Apabila media pembelajaran memadai maka outputnya juga akan bagus. Terbukti dengan adanya media pembelajaran di sekolah membuat siswa lebih tertarik dalam proses belajar mengajar, sedangkan sekolah yang belum memiliki media pembelajaran yang lengkap membuat guru akan sulit untuk mengajar karena fasilitasnya yang belum lengkap. Fasilitas yang ada merupakan faktor pentingupaya guru memaksimalkan programnya, fasilitas yang kurang lengkap akan menjadi kendala yang berarti bagi seorang guru dalam beraktifitas.

Salah satu kreativitas guru dapat dilihat bagaimana guru mengembangkan media pembelajaran dengan memanfaatkan berbagai alat dan sumber belajar di lingkungannya. Guru tidak hanya dituntut dapat memanfaatkan media pembelajaran, tetapi juga harus dapat mengembangkan media pembelajaran dari tingkat sederhana sampai dengan canggih. SMA Negeri 1 Moga mempunyai media pembelajaran yang kurang lengkap, seperti belum tersedianya alat musik modern (keyboard) yang memenuhi standart. Kurang terawatnya media pembelajaran seni musik seperti gitar, drum, dan keyboard sehingga meskipun alatnya tersedia dan ada tapi sudah tidak layak untuk digunakan dalam pembelajaran. Selain itu guru belum menggunakan media-media lain seperti laptop, iringan musik serta video-video pembelajaran, sehingga guru menjadi sulit dalam mengajar dan siswa menjadi kurang tertarik dengan apa yang diajarkan oleh guru. 
1. Kurang terawatnya fasilitas sarana dan pra sarana

Pembelajaran drum di SMA Negeri 1 Moga tentunya membutuhkan sarana dan pra sarana yang baik, sehingga proses kegiatan pembelajaran virtual drum baik di kelas maupun di laboratorium musik tetap berjalan. Kurang terawatnya fasilitas yang ada di laboratorium musik di SMA Negeri 1 Moga menjadi faktor penghambat kreativitas guru, karena kualitas alat musik drum yang ada di laboeatorium yang kurang terawat tidak bisa menghasilkan suara yang maksimal sehingga siswa tidak tahu bagaimana suara alat musik drum yang bagus dan berkualitas. Hal ini berpengaruh besar pada pembelajaran drum di SMA Negeri 1 Moga. 


\section{BAB V}

\section{PENUTUP}

\subsection{Simpulan}

Kreativitas guru dalam pembelajaran drum di SMA Negeri 1 Moga cukup kreatif. Hal ini ditunjukkan dengan guru mengajarkan cara bermain drum secara virtual dengan langkah-langkah seperti menentukan tema pembelajaran drum secara virtual, membuat pola-pola sederhana dalam pembelajaran drum secara virtual dan membuat langkah-langkah pola sederhana pembelajaran drum secara virtual. Kreativitas lain yang dimiliki guru di SMA Negeri 1 Moga yaitu, guru memperkenalkan komponen-komponen alat musik drum, dengan langkah memperlihatkan secara langsung kepada siswa komponen alat musik drum dan menyebutkan fungsi komponen utama alat musk drum. Guru SMA Negeri 1 Moga juga mengajarkan pola ritmis kepada siswa-siswi dengan menggunakan pola ritmis sederhana sehingga siswa dapat menirukan pola ritmis dengan mudah.

Faktor pendukung yang dapat menunjang kreativitas guru dalam pembelajaran drum meliputi: (1) faktor internal yakni: referensi buku, sarana dan prasarana dan keaktifan siswa; (2) faktor eksternal yakni lingkungan kebudayaan yang dapat mempengaruhi kreativitas individu. Sedangkan faktor penghambat kreativitas guru dalam pembelajaran drum meliputi: (1) keterbatasan dana; (2) keterbatasan kemampuan guru; (3) keterbatasan media pembelajaran; dan (4) kurang terawatnya fasilitas sarana dan prasarana. 


\subsection{Saran}

Berdasarkan penelitian dan pembahasan, maka saran yang dapat diberikan adalah sebagai berikut :

1. Guru diharapkan dapat lebih mengembangkan kreativitasnya dalam materi pembelajaran yang lain.

2. Guru diharapkan lebih memperdalam pengetahuan musiknya agar dapat mengembangkan kreativitas musik yang lainnya supaya menjadi lebih baik dan materi pembelajaran lebih menarik.

3. Bagi sekolah diharapkan lebih melengkapi sarana dan prasarana terutama media pembelajaran seni musik, jika sudah ada maka perlu perawatan yang baik supaya kualitas alat musik yang sudah ada tetap bisa terjaga dan membantu dalam pembelajaran seni musik lainnya. 


\section{DAFTAR PUSTAKA}

Al Hafith, Hukama. 2016. Kreativitas Guru dalam Pembelajaran Ekstrakurikuler Band di SMP Negeri 3 Batang. Semarang: UNNES Press.

Arikunto, Suharsini.1993. Prosedur Penelitian Suatu Pendekatan Praktek. Jakarta: PT Bima Aksara.

Boeree, C.George. 2009. Metode Pembelajaran dan Pengajaran. Yogyakarta: Arruz Media

Darsono, dkk. 2000.Belajar dan Pembelajaran. Semarang: CV. IKIP Semarang Press.

Departemen Pendidikandan Kebudayaan. 1990. KamusBesarBahasa Indonesia. Jakarta: BalaiPustaka

Dimyati dan Mudjiono. 2006. Belajar dan Pembelajaran. Jakarta: Rineka Cipta.

Fathurrohman, Pupuh dan M. Sobry Sutikno S. 2007. Strategi Belajar Mengajar Melalui Penanaman Konsep Umum dan Konsep Islami. Bandung: PT Refika Aditama

Hamalik, Oemar. 2013. Proses Belajar Mengajar. Jakarta: Bumi Aksara. . 2008. Kurikulum dan Pembelajaran. Jakarta: Bumi Aksara.

Haryono, Slamet dan Langlang Handayani. Uji Akustik Limbah Film Roentgen Sebagai Bahan Alternatif Pengganti Membran Alat Musik Drum. (2006). Harmonia Jurnal Pengetahuan dan Pemikiran Seni. 7 (3), PP. 921-929.

Jamalus. 1988. Pengajaran Musik Melalui Pengalaman Musik. Jakarta:

Depdikbud.

1998. Pengajaran Musik Melalui Pengalaman Musik. Jakarta: Depdikbud.

Joseph, Wagieman. Pembelajaran Musik Kreatif Pada Anak Usia Dini. (2004). Harmonia Jurnal Pengetahuan dan Pemikiran Seni. 5 (1), PP. 601-611.

Kemdikbud. 2016. Seni Budaya SMA/MA/SMK/MAK Kelas X. Jakarta : Pusat Kurikulum dan Pembukuan, Kulitbang, Kemdikbud 
Kristiawan, Y. 2015. Pengembangan Kreativitas Musik Dalam Pembelajaran Seni Budaya di SMA Negeri 1 Pati. Skripsi. Semarang: Universitas Negeri Semarang.

Moleong, Lexy J. 1990. Metode Penelitian Kualitatif. Bandung: PT Remaja Rosda Karya.

Moleong, Lexy J. 1990. Metode Penelitian Kualitatif. Bandung: PT Remaja Rosda Karya

Moleong. 1989. Metode Penelitian Kualitatif. Bandung: PT Remaja Rosda Karya.

Milles, M.M danHuberman, A.M. 1992. Terjemahan T. RehendiRohidi.Analisis Data Kualitatif. Jakarta: Universitas Indonesia.

Munandar, Utami. 1985. Mengembangkan Bakat dan Kreativitas Anak Sekolah: Petunjuk Bagi Para Guru Dan Orang Tua. Jakarta: Gramedia Pustaka Utama. Rineka Cipta.

Nasir, Moh. 1985. MetodePenelitian. Jakarta: Ghalia Jakarta.

Nur Rohmah, Annisa dan Nanang Yulianto. Seni Budaya untuk SMA/MA/SMK kelas $X$. Surakarta : Mediatama

Nurul Imansyah, Ilham. 2013. Virtual Musik dan Jenisnya. www.meinspiration.blogspot.com di akses pada tanggal 24 Agustus 2017.

Rachman, Abdul, Udi Utomo dan Hanif Iwan Saputra. 2016. Penggunaan Media Backingtrack Pada Pembelajaran Mata Kuliah Keroncong di Jurusan SENDRATASIK Uneiversitas Negeri Semarang. Semarang: Universitas Negeri Semarang.

Rohidi. 1993. Analisis Data Kualitatif dalam Matthew M. Milesdan A. Michael Huberman (terjemahan). Jakarta: UI Press.

Ryanto. 2014. Analisis dan Pembuatan Virtual Drum Sebagai Media Belajar Berbasis Android. Yogyakarta: STMIK AMIKOM Press.

Sitofu, R. 2015. Kreativitas Guru dalam Pembelajaran Seni Musik di TK Pertiwi 34 Kelurahan Patemon Kecamatan Gunungpati Kota Semarang. Skripsi. Semarang : Universitas Negeri Semarang.

Sugiyono. 2010. Metode Penelitian Pendidikan Pendekatan Kuantitatif, Kualitatif, dan $R \& D$. Bandung: Alfabeta. 
Sumaryanto, Totok. 2007. Pendekatan Kuantitatif dan Kualitatif dalam Penelitian Pendidikan Seni. Semarang: Unnes Press.

Suharto \& Indriyanto. 2017. Musik Calung Banyumasan.Semarang: Sendratasik Press.

Ambarwangi, Sri; Suharto, Suharto. Reog as Means of Students' Appretiationand Creation in Arts and Culture Based on the Local Wisdom. Harmonia: Journal of Arts Research and Education, [S.1.], v. 14, n. 1, p. 37-45, Mar. 2014. ISSN 2541-2426. Available at: <https://journal.unnes.ac.id/nju/index.php/harmonia/article/view/2789>. $\begin{array}{llll}\text { Date } & \text { accessed: } & 17 & \text { Jan. }\end{array}$ doi:http://dx.doi.org/10.15294/harmonia.v14i1.2789.

Suharto, S., \& Aesijah, S. (2014). THE LESUNG MUSIC IN THE VILLAGE OF LEDOK BLORA REGENCY. Harmonia: Journal Of Arts Research And Education, $14(1)$, doi:http://dx.doi.org/10.15294/harmonia.v14i1.2851

65-71.

Handayaningrum, W. (2016). Science-Based Thematic Cultural Art Learning in Primary School (2013 Curriculum). Harmonia: Journal Of Arts Research And Education, 16(1), 14-23. doi:http://dx.doi.org/10.15294/harmonia.v16i1.6766

Suharto, S. (2013). PROBLEMATIKA PELAKSANAAN PENDIDIKAN SENI MUSIK DI SEKOLAH KEJURUAN NON SENI. Harmonia: Journal Of Arts Research And Education, 12(1). doi:http://dx.doi.org/10.15294/harmonia.v12i1.2221

Suharto, S. (2000). ACTION RESEARCH TO SOLVE MUSIC TEACHING PROBLEMS IN THE SCHOOL. Harmonia: Journal Of Arts Research And Education, 1(1). doi:http://dx.doi.org/10.15294/harmonia.v1i1.835

Suharto, S. (2011). PENGEMBANGAN MATERI DAN KEGIATAN PEMBELAJARANNYA DALAM KURIKULUM TINGKAT SATUAN PENDIDIKAN BIDANG SENI MUSIK. Harmonia: Journal Of Arts Research And Education, 8(3). doi:http://dx.doi.org/10.15294/harmonia.v8i3.780

Utomo,U \& Suharto.. 2014. Materi Ajar Strategi Belajar Mengajar Seni Musik. Semarang: Universitas Negeri Semarang.

Utomo, Udi. 2016. Musik Pendidikan. Semarang: Universitas Negeri Semarang.

Utuh, H. 1987. Proses Belajar Mengajar. Surabaya: Usaha Nasional. 
Widodo, Tri Wahyu. Komputer dan Pengetahuan Program Aplikasi Musik Komputer. (2006). Harmonia Jurnal Pengetahuan dan Pemikiran Seni. 7 (2), PP. 671-684.

Wikipedia.2017.Pengertian Drum dan Jenis-jenisnya. www.wikipedia.pengertiandrumdanjenisnya.com diakses pada tanggal 23 Agustus 2017.

Williancesna. 2012. Belajar bermain drum dengan virtual drumming. . www.williancesna.blogspot.com diakses pada tanggal 24 Agustus 2017.

Witharto, Bagus. 2012. Media Pembelajaran Alat Musik Drum Serta Aplikasi Virtual Drum Untuk Pemula Anak Usia 7-12 Tahun. Semarang : Universitas Dian Nuswantoro.

Yogo W, Herwin. 2009. "Kreativitas Pembelajaran Musik (Jurnal KreativiatasPembelajaran Musik)". Yogyakarta: Jurusan Pendidikan Seni Musik, Fakultas Bahasa dan Seni, Universitas Negeri Yogyakarta.

Zamaludin. 2013. Cara main drum online.. www.zamaludin's.blogspot.com diakses pada tanggal 26 Agustus 2017. 


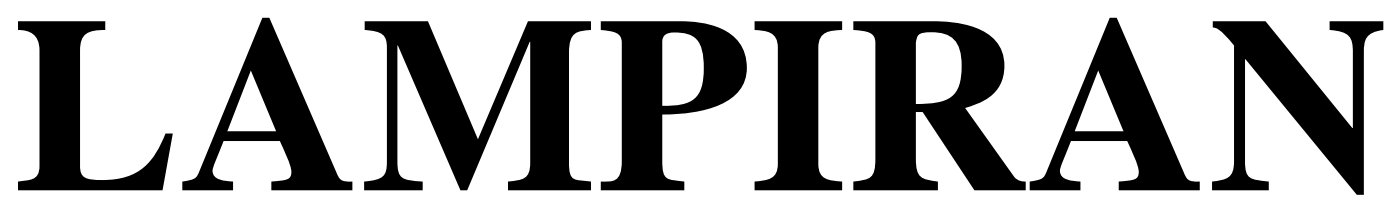

Instrumen Penelitian

I. Pedoman Observasi 
Observasi penelitian ini dilakukan di SMA Negeri 1 Moga Kelurahan Banyumudal Kecamatan Moga Kota Pemalang. Rencana Observasi dilakukan sebanyak 2 kali dengan rincian sebagai berikut :

A. Keadaan SMA Negeri 1 Moga, yang meliputi :

a. Lokasi SMA Negeri 1 Moga

b. Ruang Kelas X Bahasa SMA Negeri 1 Moga

c. Sarana Prasarana dalam proses pembelajaran maupun diluar pembelajaran

B. Kegiatan pembelajaran virtual drum di SMA Negeri 1 Moga

a. Pembelajaran drum secara virtual hari pertama

1. Tindakan

\begin{tabular}{|c|c|c|c|}
\hline No. & Pengamatan & & Hasil Pengamatan \\
\hline 1. & $\begin{array}{l}\text { Guru } \\
\text { a. Pembukaan } \\
\text { b. Materi } \\
\text { c. Penutup }\end{array}$ & a. & $\begin{array}{l}\text { Pembukaan } \\
\text { Guru memperkenalkan } \\
\text { alat musik drum kepada } \\
\text { siswa } \\
\text { Materi } \\
\text { Guru menjelaskan } \\
\text { pngertian, komponen- } \\
\text { komponen, dan fungsi } \\
\text { alat musik drum } \\
\text { Guru mengulang kembali }\end{array}$ \\
\hline
\end{tabular}




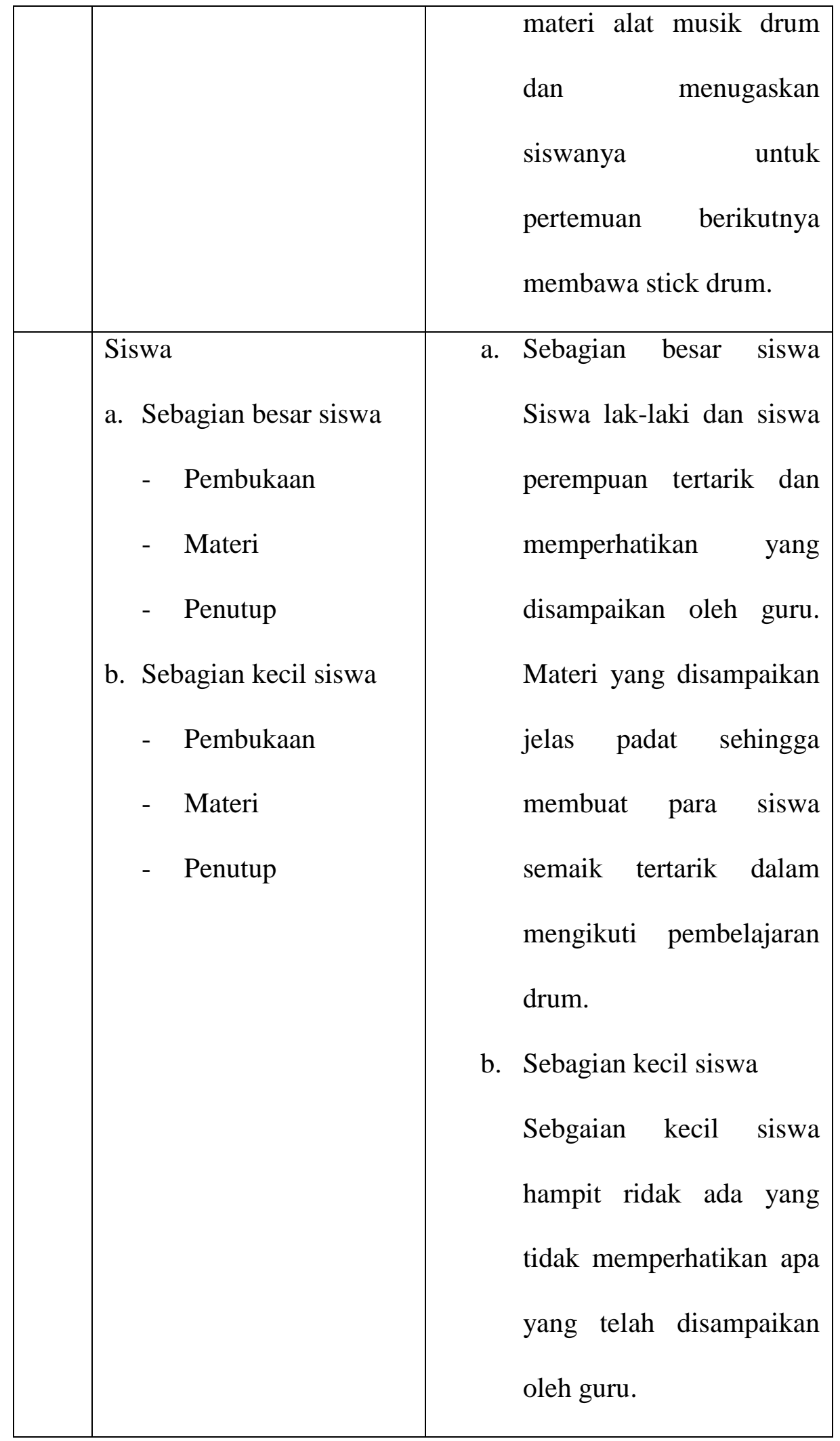


b. Pembelajaran drum secara virtual hari kedua

\section{Tindakan}

\begin{tabular}{|c|c|c|c|}
\hline No. & Pengamatan & & Hasil Pengamatan \\
\hline 1. & $\begin{array}{l}\text { Guru } \\
\text { d. Pembukaan } \\
\text { e. Materi } \\
\text { f. Penutup }\end{array}$ & a. & $\begin{array}{l}\text { Pembukaan } \\
\text { Guru mengingatkan } \\
\text { kembali minggu lalu } \\
\text { tentang pengertian, } \\
\text { komponen-komponen, } \\
\text { dan fungsi drum. } \\
\text { Materi } \\
\text { Guru menjelaskan } \\
\text { pembelajaran drum secara } \\
\text { virtual. Pengertian dan } \\
\text { cara-cara memainkan } \\
\text { drum secara virtual. } \\
\text { Setelah itu guru } \\
\text { mempraktekkan kepada } \\
\text { siswanya, setelah senua } \\
\text { siswa mengerti siswa } \\
\text { kemudian siswa mencoba } \\
\text { satu persatu ke alat musik }\end{array}$ \\
\hline
\end{tabular}




\begin{tabular}{|c|c|c|}
\hline & & $\begin{array}{l}\text { drum yang sesungguhnya. } \\
\text { Penutup } \\
\text { Guru menugaskan ke } \\
\text { siswa untuk mengambil } \\
\text { penilaian di pertemuan } \\
\text { selanjutnya. }\end{array}$ \\
\hline $\begin{array}{l}\text { Siswa } \\
\text { c. Sebagian besar siswa } \\
\text { - Pembukaan } \\
\text { - } \text { Materi } \\
\text { - Penutup } \\
\text { d. Sebagian kecil siswa } \\
\text { - Pembukaan } \\
\text { - Materi } \\
\text { - Penutup }\end{array}$ & a. & $\begin{array}{l}\text { Sebagian Besar siswa } \\
\text { Siswa mulai bisa } \\
\text { mengikuti apa yang di } \\
\text { arahkan oleh guru } \\
\text { mengenai pembelajaran } \\
\text { drum secara virtual drum, } \\
\text { mengikuti gerakan- } \\
\text { gerakan yang diajarkan } \\
\text { dalam pembelajaran drum } \\
\text { virtual drum tersebut, } \\
\text { sebagian besar siswa bisa } \\
\text { memainkan drum secara } \\
\text { virtual tersebut meskipun } \\
\text { siswa belum pernah sama } \\
\text { sekali memainkan drum. } \\
\text { Sebagian kecil siswa ada }\end{array}$ \\
\hline
\end{tabular}




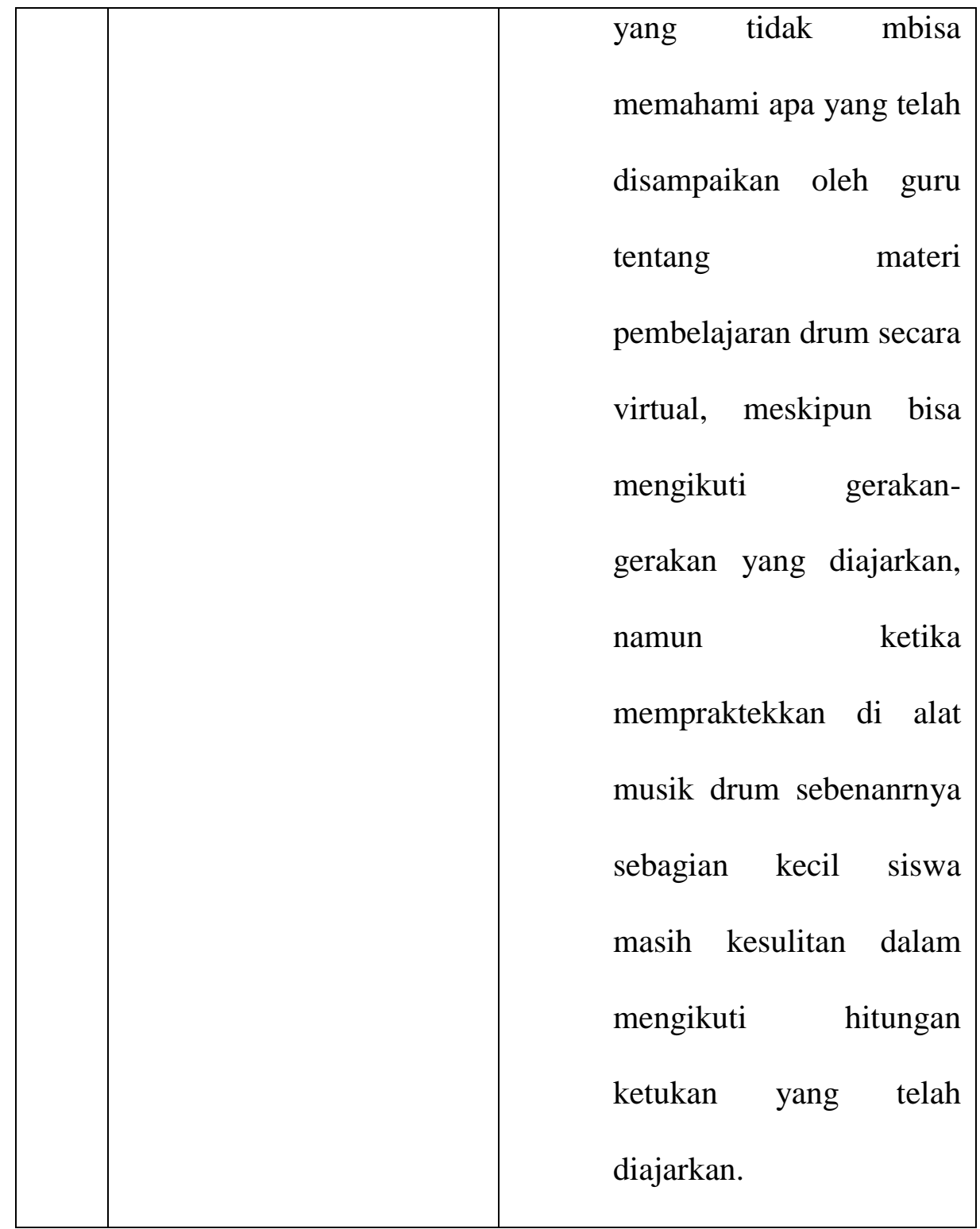

D. Media dalam pembelajaran seni musik di SMA Negeri 1 Moga
a. Papan Tulis
b. Buku ajar
c. Stick drum
d. Alat musik drum 
E. Metode yang dilakukan guru dalam pembelajaran drum di SMA Negeri 1 Moga

a. Mengenalkan bagian-bagian drum

b. Menjelaskan pengertian pembalajaran drum secara virtual

c. Mengajarkan cara memainkan drum secara virtual

d. Mencontohkan materi pembelajaran drum secara virtual yang akan diajarkan kepada siswa

e. Siswa mempraktikkan pembelajaran drum secara virtusl dengan alat musik drum yang sebenarnya.

\section{Panduan Wawancara}

Pihak-pihak yang bersangkutan dalam penelitian ini meliputi : Kepala Sekolah, guru, dan siswa.

Responden : Kepala Sekolah SMA Negeri 1 Moga

Daftar Pertanyaan

1. Sejak kapan SMA Negeri 1 Moga berdiri?

2. Berapa jumlah tenaga pendidik di SMA Negeri 1 Moga?

3. Berapa jumlah kelas di SMA Negeri 1 Moga?

4. Berapa jumlah siswa setiap kelas?

5. Bagaimana kualitas sarana dan prasarana di SMA Negeri 1 Moga?

6. Apakah kondisi lingkungan sudah mendukung berjalannya proses belajar mengajar? 
7. Bagaimanakah proses kegiatan pembelajaran virtual drum di SMA Negeri 1 Moga?

8. Bagaimana sarana prasarana dalam menunjang pembelajaran virtual drum di SMA Negeri 1 Moga?

\section{Responden : Guru SMA Negeri 1 Moga}

Daftar Pertanyaan

1. Metode apa saja yang Bapak gunakan dalam pembelajaran?

2. Alat peraga/media apa saja yang digunakan dalam pembelajaran?

3. Bagaimana strategi pembelajaranya seni musik di SMA Negeri 1 Moga?

4. Apa kreativitas Bapak dalam pembelajaran drum di SMA Negeri 1 Moga?

5. Bagaimana strategi Bapak dalam pengelolaan kelas? Apakah efektif dalam pembelajaran virtual drum?

6. Bagaimana cara menyampaikan materi kepada siswa?

7. Kesulitan apa saja yang Bapak alami dalam pembelajaran?

8. Apa hasil dari metode pembelajaran yang Bapak sampaikan kepada siswa?

9. Mengapa Bapak memilih metode tersebut? Apa kelebihannya?

Responden : Siswa

Daftar pertanyaan

1. Apakah kamu senang mengikuti pelajaran virtual drum tersebut?

2. Kesulitan apa saja yang kamu alami dalam pembelajaranvirtual drum? 
III. Panduan Dokumentasi
a. Data Struktur organisasi sekolah
b. Data Staf pengajar dan karyawan
c. Daftar siswa tahun ajaran $2016 / 2017$
d. Daftar siwa kelas X Bahasa
e. Data Prestasi Siswa
f. Foto SMA Negeri 1 moga
g. Foto kegiatan pembelajaran
h. Foto fasilitas penunjang kegiatan pembelajaran drum di SMA Negeri 1
Moga

Lampiran 2

Transkrip Wawancara 
Responden : Kepala SMA Negeri 1 Moga

Daftar pertanyaan

1. Sejak kapan SMA Negeri 1 Moga berdiri?

Jawaban : Sekitar tahun 1999 dan mulai beroperasi sekitar tahun 1999 juga.

2. Berapa jumlah tenaga pendidik di SMA Negeri 1 Moga?

Jawaban : Ada 43 guru (termasuk guru tidak tetap) dan 17 tenaga administrasi

3. Berapa jumlah kelas di SMA Negeri 1 Moga?

Jawaban : Ada 27 kelas, masing-masing 9 kelas untuk kelas X (Bahasa, IPA, dan IPS), 9 kelas untuk kelas XI (Bahasa, IPA, dan IPS), dan 9 kelas untuk kelas XII (Bahasa, IPA, dan IPS).

4. Berapa jumlah siswa setiap kelas?

Jawaban : Setiap kelas jumlahnya siswanya tidak sama, namun masih berkisar antara 38, 39, dan 40 siswa setiap kelas.

5. Bagaimana kualitas sarana dan prasarana di SMA Negeri 1 Moga?

Jawaban : Kualitas sarana dan prasarana cukup memadai, hampir senua fasilitas bisa di manfaatkan dengan baik.

6. Apakah kondisi lingkungan sudah mendukung berjalannya proses belajar mengajar?

Jawaban : Kondisi lingkungan sudah mendukung, karena letak SMA Negeri 1 Moga jauh dari jalan raya dan tempat keramaian sehingga suasana kingkungan sangat mendukung dalam pembelajaran. 
7. Bagaimanakah proses kegiatan pembelajaran virtual drum di SMA Negeri 1 Moga?

Jawaban : Kegiatan pembelajaran virtual drum di SMA Negeri 1 Moga berjalan dengan lancar karena kreativitas guru lah pembelajaran bisa berajalan.

8. Bagaimana sarana prasarana dalam menunjang pembelajaran virtual drum di SMA Negeri 1 Moga?

Jawaban : Karena kurangnya sarana dan pra sarana yang cukup memadai serta kurang terawatnya sarana pra sarana ang sudah tersedia sehingga pembelajaran virtual drum di sekolah berjalan dengan menggunakan sarana yang ada, kecuali jika sarana bisa diupayakan oleh guru dan siswa menurut saya semua sarana bisa dimanfaatkan dengan baik.

Responden : Guru SMA Negeri 1 Moga

Daftar Pertanyaan

1. Metode apa saja yang Bapak gunakan dalam pembelajaran virtual drum? Jawaban : Metode drill dan demonstrasi, karena dengan cara mengulangulang materi yang sudah diajarkan kepada siswa, siswa akan memiliki daya ingat yang sangat kuat terhadap materi yang telah saya ajarkan.

2. Alat peraga/media apa saja yang digunakan dalam pembelajaran virtual drum?

Jawaban : Alat peraga yang saya gunakan adalah tangan kanan untuk cymbal drum, kaki kanan untuk bass pedal drum, dan tangan kiri untuk 
snare drum. Selain itu media yang saya gunakan adalah stick drum dan papan tulis.

3. Bagaimana strategi pembelajaran drum di SMA Negeri 1 Moga?

Jawaban : Strategi yang saya gunakan adalah membuat alat peraga dengan pola-pola yang mudah dimengerti oleh siswa, sehingga siswa dapat mengerti apa yang telah saya sampaikan.

4. Apa kreativitas Bapak dalam pembelajaran virtual drum di SMA Negeri 1 Moga?

Jawaban : Kreativitas saya dalam pembelajaran drum adalah dapat mengajarkan kepada siswa pembelajaran drum secara virtual tanpa harus mempunyai alat musik drum yang sebenarnya.

5. Bagaimana strategi Bapak dalam pengelolaan kelas? Apakah efektif dalam pembelajaran virtual drum?

Jawaban : Sejauh ini, strategi saya dalam pengeloalaan kelas cukup efektif dengan cara jika siswa tidak bisa mengikuti pelajaran yang saya ajarkan dengan baik dengan kata lain gaduh, maka dengan senang hati akan saya keluarkan dari kelas. Cara ini sangat efektif, sehingga mau tidak mau siswa harus dituntut konsentrasi dalam pembelajaran drum tersebut.

6. Bagaimana cara menyampaikan materi kepada siswa?

Jawaban : Saya menggunakan metode eksperimen dengan cara satu persatu siswa mempraktikkan materi virtual drum yang saya sampaikan.

7. Kesulitan apa saja yang Bapak alami dalam pembelajaran virtual drum? 
Jawaban : Kesulitan yang saya alami pada saat menyampaikan materi pembelajaran kepada siswa adalah dimana siswa tidak memiliki pengalaman musik yang sudah ada dan kebanyakan terjadi pada siswa perempuan, namun jika pada saat awal pembelajaran virtual drum siswa mendengarkan dan mencermati dengan baik maka meskipun siswa tidak memliki pengalaman musik tetap bisa memainkan drum dengan pembelajaran drum secara virtual.

8. Apa hasil dari metode pembelajaran yang Bapak sampaikan kepada siswa? Jawaban : Hasil dari metode yang saya gunakan hampir semua siswa mampu memainkan alat musik drum meskipun siswa tersebut tidak pernah sama sekali memainkan drum.

9. Mengapa Bapak memilih metode tersebut? Apa kelebihannya? Jawaban : Saya memilih metode virtual dalam pembelajaran drum karena menurut saya memainkan alat musik drum cukup sulit jika tidak ada alat musik drum yang sebenarnya, dengan adanya pembelajaran virtual drum saya bisa mengajarkan bagaimana cara memainkan dasar-dasar dalam memainkan alat musik drum. Kelebihannya adalah siswa bisa memainkan alat musik drum meskipun siswa tersebut tidak pernah sama sekali memainkan alat musik drum.

Responden : Siswa

Daftar pertanyaan 
1. Apakah kamu senang mengikuti pembelajaran virtual drum tersebut? Jawaban : Saya senang, karena saya memang tidak bisa bermain drum sedikit demi sedikit saya bisa bermian alat musik drum.

2. Kesulitan apa saja yang kamu alami dalam pembelajaran virtual drum? Jawaban : Kesulitan yang saya alami cara memegang stick drum yang benar dan menyeimbangkan ketukan dengan tanagn kanan, kaki kanan, dan tangan kiri. 


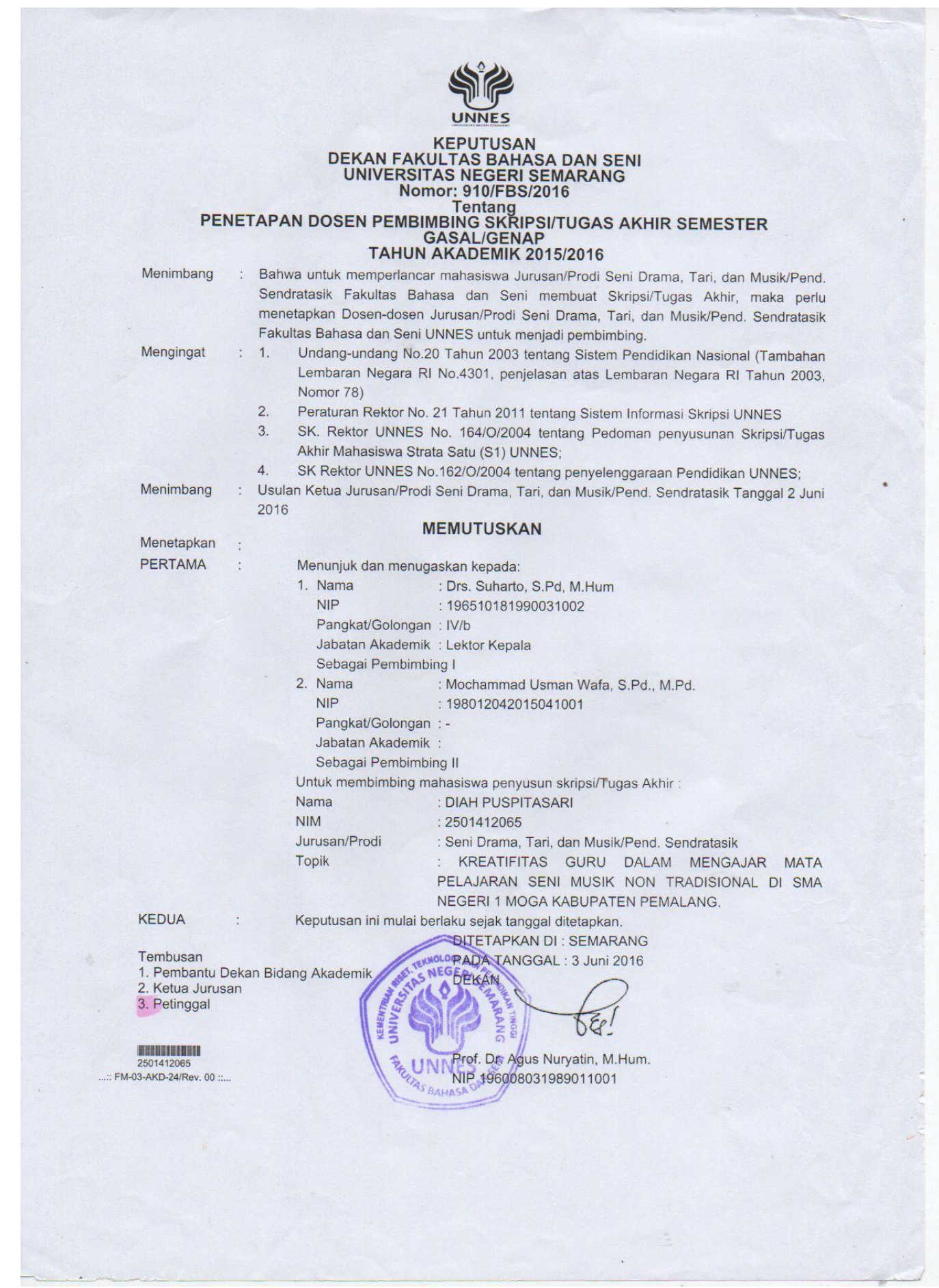




\section{PEMERINTAH PROVINSI JAWA TENGAH} DINAS PENDIDIKAN DAN KEBUDAYAAN

SMA NEGERI 1 MOGA

Jalan Raya Camping Sight Desa Banyumudal Kecamatan Moga 0284 583449 PEMALANG 52354

Website : www.sman1moga. Sch.id Email : sman1moga_pml@yahoo.co.id

\section{SURAT KETERANGAN}

Nomor : 070/ 190/2017

Yang bertanda tangan di bawah ini Kepala SMA Negeri 1 Moga Kabupaten Pemalang menerangkan bahwa :
Nama
Diah Puspitasari
NIM
: 2501412065
Jurusan/Fakultas
: Pendidikan Seni Musik/Bahasa dan Seni
Perguruan Tinggi
: UNNES Semarang

Bahwa yang bersangkutan namanya tersebut diatas telah melaksanakan Penelitian di SMA Negeri 1 Moga dengan judul " Kreativitas Guru dalam Pembelajaran Seni Musik di SMA Negeri 1 Moga Pemalang" pada tanggal, 4 April s,d 3 Mei 2017 untuk Skripsi.

Demikian surat keterangan ini diberikan kepada yang bersangkutan untuk dapat dipergunakan sebagaimana mestinya.

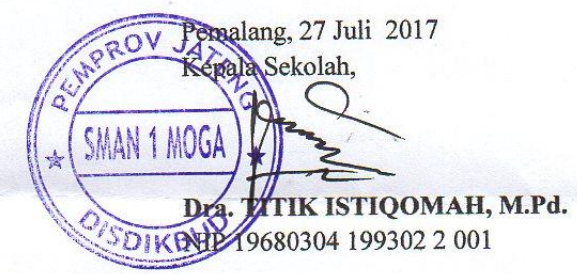




\section{Lampiran 5}

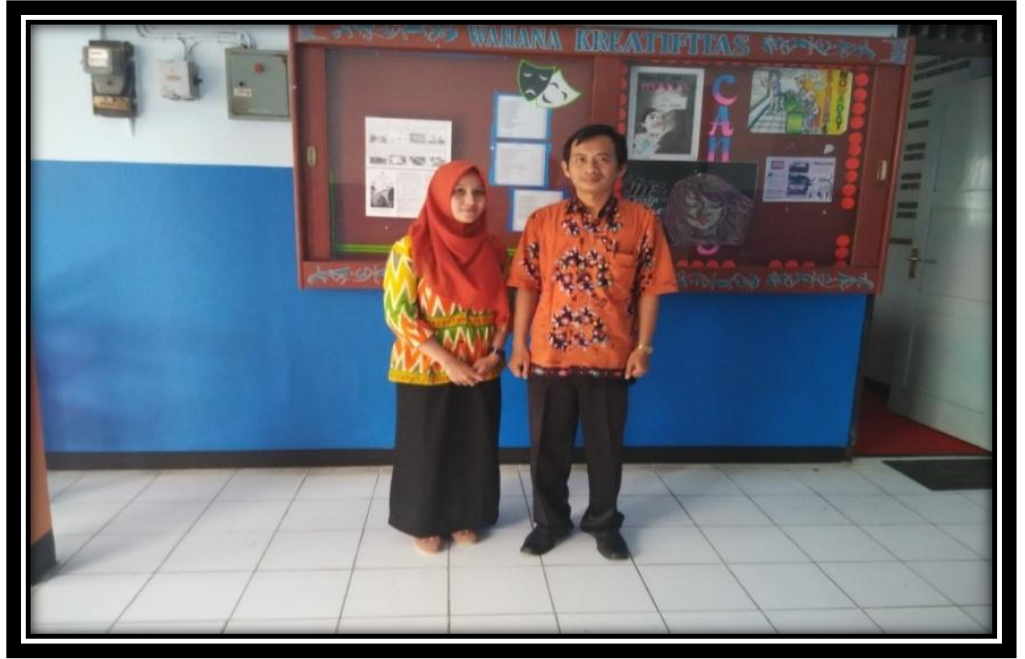

Gambar 4.17 Peneliti bersama Bapak Erwanto, S.Pd selaku guru seni musik di SMA Negeri 1 Moga

(Diah Puspitasari, 6 April 2017)

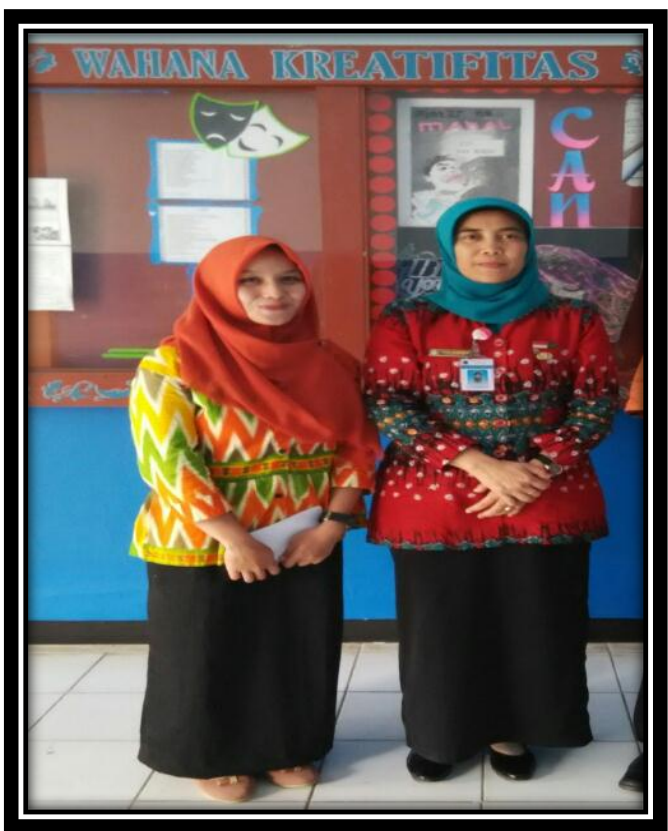

Gambar 4.18 Peneliti bersama Ibu Dra. Titik Istiqomah, M.Pd selaku Kepala Sekolah SMA Negeri 1 Moga

(Diah Puspitasari, 6 April 2017) 


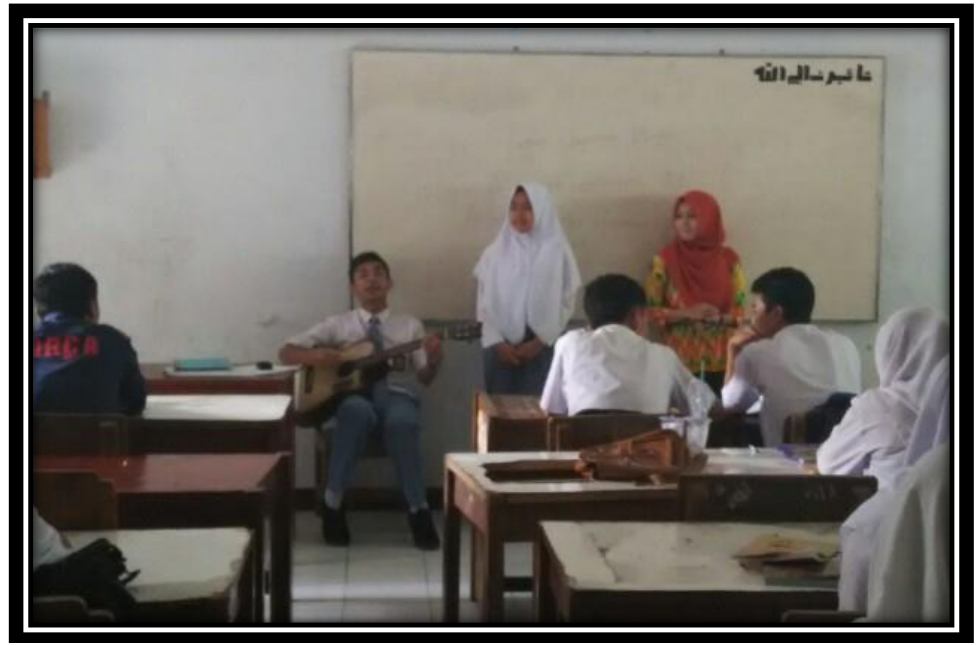

Gambar 4.19 Peneliti dengan siswa pada saat mengisi waktu setelah penelitian (Diah Puspitasri, 6 April 2017)

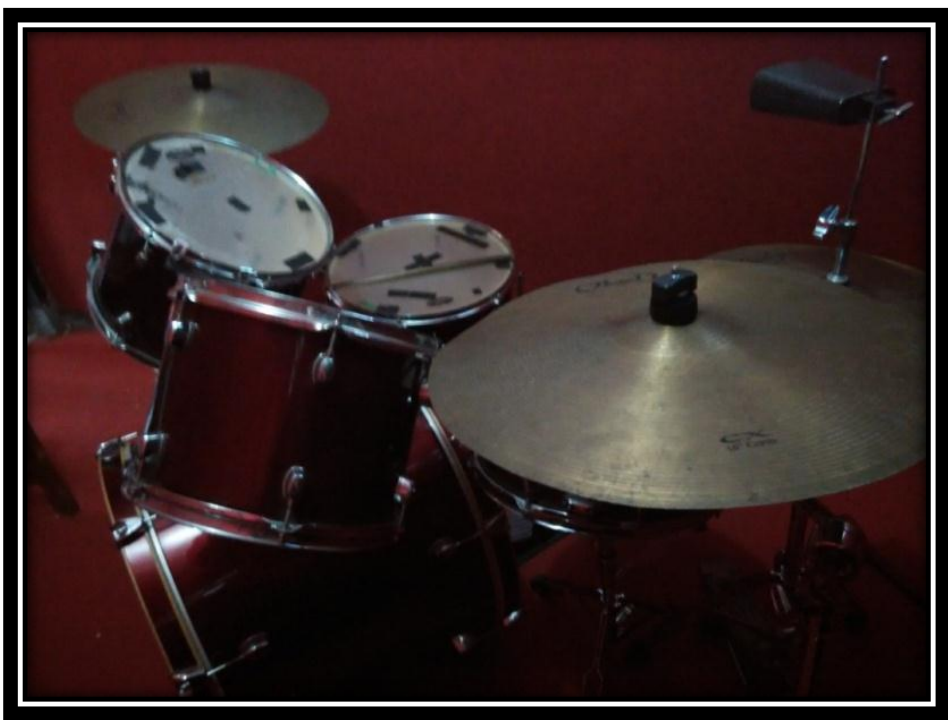

Gambar 4.20 Alat musik drum SMA Negeri 1 Moga (Diah Puspitasari, 10 april 2017) 


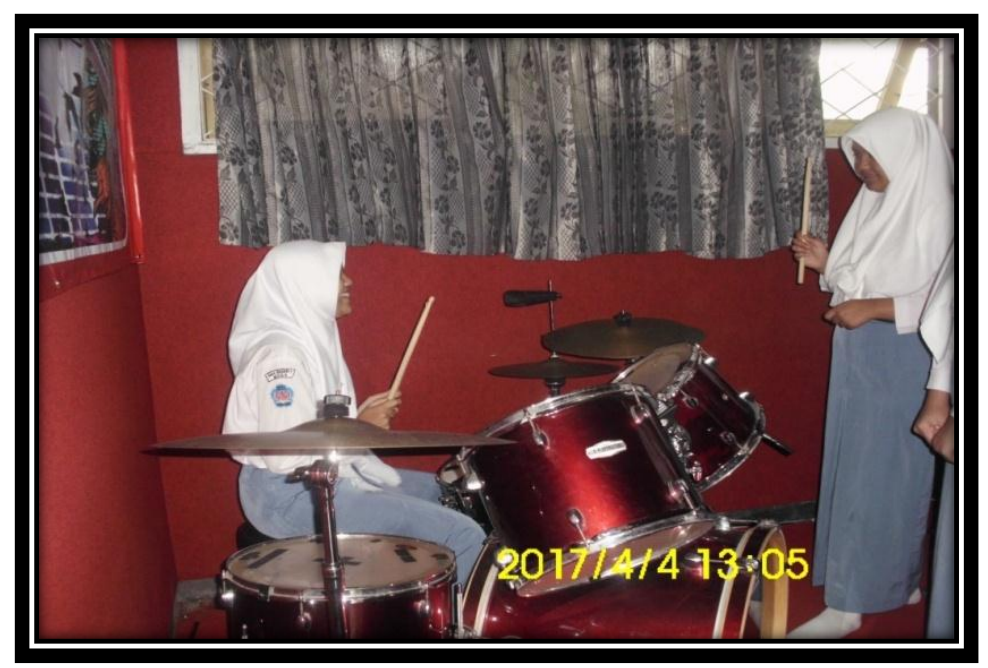

Gambar 4.21 Siswa sedang bermian alat musik drum dengan pembelajaran virtual drum

(Diah Puspitasari, 4 April 2017)

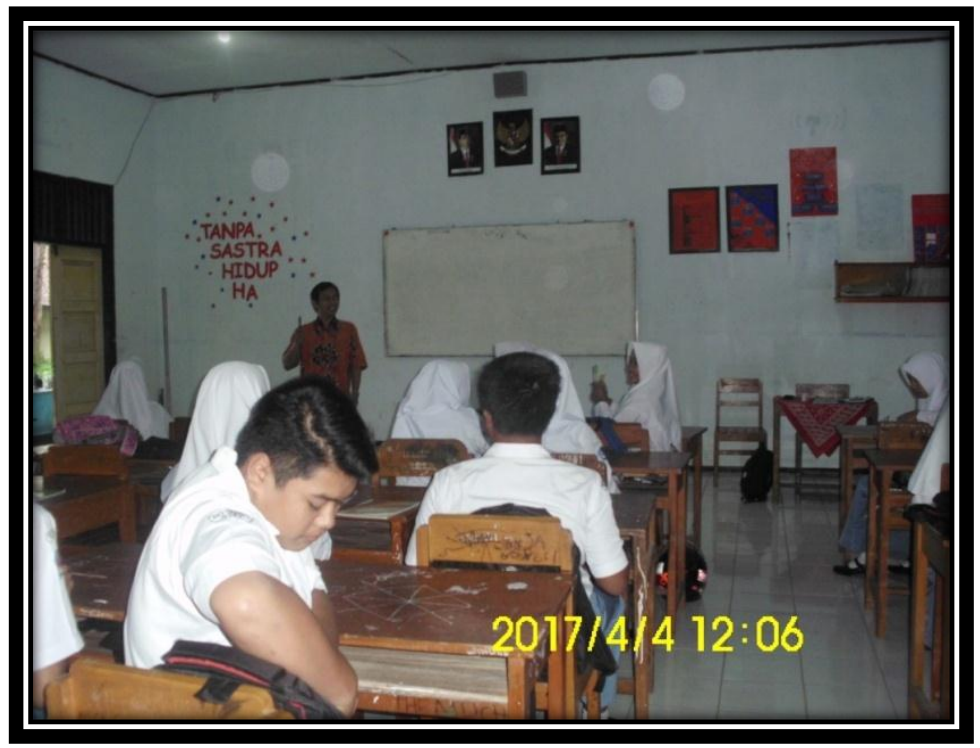

Gambar 4.22 Guru sedang menerangkan pembelajaran drum (Diah Puspitasari, 4 April 2017) 


\section{RENCANA PELAKSANAAN PEMBELAJARAN}

$\begin{array}{ll}\text { Sekolah } & \text { : SMA Negeri } 1 \text { Moga } \\ \text { Matapelajaran } & : \text { Seni Budaya (Seni musik) } \\ \text { Kelas/Semester } & : \text { X/satu } \\ \text { Materi Pokok } & : \text { Penyajian karya musik } \\ \text { Alokasi Waktu } & : 3 \times 2 \text { JP }\end{array}$

A. Tujuan Pembelajaran

Melalui proses melihat, mengamati, menanyakan dan berdiskusi siswa dapat:

- Mampu menjelaskan wawasan tentang jenis, konsep, teknik penyajian karya musik

- Mampu menyebutkan jenis-jenis penyajian karya musik

- Mampu menjelaskan media dan teknik penyajian karya musik

- Mampu menyebutkan media dan teknik penyajian karya musik

- Mampu mengumpulkan informasi tentang jenis, konsep, teknik penyajian karya musik dari berbagai sumber

- Mampu mengumpulkan informasi tentang media dan teknik penyajian karya musik dari berbagai sumber

- Mampu menjelaskan metode virtual drum

- Mampu mempraktikkan penyajian karya musik dengan metode virtual drum

- Mampu mengapresiasi penyajian karya musik

\section{B. Kompetensi Dasar dan Indikator}

1. KD. 1.1 Menunjukkan sikap penghayatan dan pengamalan serta bangga terhadap karya seni musiksebagai bentuk rasa syukur terhadap anugerah Tuhan.

2. KD. 2.1 Menunjukkan sikap kerjasama, bertanggung jawab, toleran, dan disiplin melalui aktivitas berkesenian.

3. KD. 2.2 Menunjukkan sikap santun, jujur, cinta damai dalam mengapresiasi seni dan pembuatnya.

4. KD. 2.3 Menunjukkan sikap responsif dan pro- aktif, peduli terhadap lingkungan dan sesama, serta menghargai karya seni dan pembuatnya.

5. KD.3.1 Memahami karya musik berdasarkan simbol, jenis nilai estetis dan fungsinya

6. KD.4.1 Menyajikan lagu-lagu berdasarkan jenisnya

\section{Indikator:}

- Menjelaskan wawasan tentang jenis, konsep, teknik penyajian karya musik

- Menyebutkan jenis-jenis penyajian karya musik

- Menjelaskan media dan teknik penyajian karya musik

- Menyebutkan media dan teknik penyajian karya musik

- Mengumpulkan informasi tentang jenis, konsep, teknik penyajian karya musik dari berbagai sumber

- Mengumpulkan informasi tentang media dan teknik penyajian karya musik dari berbagai sumber 
- Menjelaskan metode virtual drum

- Mempraktikkan penyajian karya musik dengan metode virtual drum

- Mengapresiasi penyajian karya musik

\section{Materi Pembelajaran}

Fakta

- jenis, konsep, teknik penyajian karya musik

- media, teknik penyajian karya musik

- metode virtual drum

- apresiasi penyajian karya musik

\section{Konsep}

Teknik dan metode penyajian karya musik merupakan kegiatan seni musik untuk dikomunikasikan sehingga dapat diapresiasi oleh masyarakat luas.

\section{Prinsip}

- Konsep , teknik dan jenis penyajian karya musik

Kemampuan dalam mempersepsi, memahami, menanggapi, mengidentifikasi dan menganlisis jenis jenis penyajian karya musik

- Media , teknik, metode virtual drum dan apresiasi penyajian karya musik Kemampuan dalam mempersepsi, memahami, menanggapi, merefleksi, menganalisis, dan mengevaluasipenyajian karya musik dengan metode virtual drum dengan kegiatan apresiasi seni

\section{Prosedur:}

- Langkah-langkah dalam mempraktikkan penyajian karya musik, seperti: menyiapkan bahan dan media, menentukan tujuan penyajian karya musik, menentukan teknik yang akan digunakan. Selanjutnya mempraktikkan penyajian karya musik, mengevaluasi hasilpenyajian karya musik dengan kegiatan apresiai seni.

D. Metode Pembelajaran

- Eksperimen

- Diskusi

- Virtual drum

- Presentasi

- Penugasan dan praktikum

E. Media, Alat, dan Sumber Pembelajaran

1. Media

LCD projector, Video pertunjukkan musik

Alat musik

\section{Sumber Belajar}

Buku Paket Seni Budaya Kelas X, Kumpulan lagu-lagu daerah, 
Buku teknik bermain musik, ensiklopedi musik indonesia, serta sumber lain yang relevan.

\section{F. Langkah-langkah Kegiatan Pembelajaran}

Setelah merefleksi pengalaman siswa tentang penyajian karya musik yang pernah mereka praktikkan, siswa saling bertanya secara lisan tentang penyajian karya musik yang pernah mereka alami. Selanjutnya siswa melihat penyajian karya musik melalui media (buku, majalah, brosur, video dsb.), dan internet, kemudian siwa saling bertanya tentang hasil pengamatan penyajian karya musik. Siswa dibagi dalam 6 (enam) kelompok dan diminta untuk mengumpulkan informasi tentang jenis, konsep dan teknik dalam penyajian karya musik, kemudian mempresentasikan hasil diskusi mereka secara bergantian. Selama proses pembelajaran dilakukan pembimbingan dan penilaian aktifitas siswa.

Setelah merefleksi pengalaman siswa tentang penyajian karya musik yang pernah mereka praktikkan atau lihat, siswa saling bertanya tentang bahan dan alat, serta media dan teknik dalam penyajian karya musik. Kemudian siswa mengamati proses penyajian karya musik melalui media audio visual, dilanjutkan dengan tanya jawab tentang proses apresiasi penyajian karya musik. Siswa secara individu diminta untuk mengidentifikasi dan menganalisis berbagai jenis hasil penyajian karya musik, selanjutnya siswa saling berdiskusi tentang bahan, media, jenis, simbol, teknik dan estetika penyajian karya musik yang sudah mereka amati. Selama proses pembelajaran dilakukan pembimbingan dan penilaian aktifitas siswa

\section{Pertemuan Kesatu:}

\begin{tabular}{|c|c|}
\hline Rincian Kegiatan & Waktu \\
\hline $\begin{array}{l}\text { Pendahuluan/Kegiatan Awal } \\
\text { - Merefleksi pengalaman siswa tentang penyajian karya musik yang } \\
\text { pernah mereka lihat dalam kegiatan bermain musik atau katalog } \\
\text { karya seni musik } \\
\text { - Menjelaskan kaitannya dengan pengalaman mereka terhadap } \\
\text { kompetensi dasar yang akan dipelajari. } \\
\text { - Menyampaikan tujuan pembelajaran. } \\
\text { - Bertanya secara lesan tentang kegiatan penyajian karya musik } \\
\text { - } \text { Sernah mereka lihat. } \\
\text { penyajian karya musik }\end{array}$ & 15 menit \\
\hline $\begin{array}{l}\text { Kegiatan Inti } \\
\text { Mengamati } \\
\text { - Siswa memperhatikan presentasi guru tentang definisi, konsep dan } \\
\text { jenis jenis penyajian karya musik } \\
\text { - Siswa mencari referensi tentang penyajian karya musikmelalui } \\
\text { media cetak (buku, majalah, brosur, dsb.), dan internet. } \\
\text { - Guru mengamati dan menilai aktifitas siswa. }\end{array}$ & 60 menit \\
\hline
\end{tabular}




\begin{tabular}{|c|c|}
\hline Rincian Kegiatan & Waktu \\
\hline $\begin{array}{l}\text { Menanyakan } \\
\text { - Siwa saling bertanya tentang hasil referensi definisi, konsep dan } \\
\text { - jenis jenis penyajian karya musik } \\
\text { Siswa saling bertanya tentang konsep penyajian karya musik seni } \\
\text { musik yang ada dan berkembang. } \\
\text { Mengeksplorasi } \\
\text { - Siswa dibagi dalam } 6 \text { (enam) kelompok. } \\
\text { - Siswa dalam kelompok diminta untuk mengumpulkan informasi } \\
\text { - } \text { Masintang jenis jenis dan contoh- contoh penyajian karya musik } \\
\text { - Giskusi mereka secara bergantian. } \\
\text { - membimbing diskusi mereka. } \\
\text { Mengasosiasi } \\
\text { - Masing-masing kelompok berdiskusi tentang jenis jenis penyajian } \\
\text { karya musik } \\
\text { - Guru membimbing dan menilai aktifitas siswa dalam berdiskusi. } \\
\text { Mengomunikasikan } \\
\text { - Siswa dalam kelompok menyampaikan hasil pengumpulan dan } \\
\text { - Mimpulan informasi yang diperoleh } \\
\text { - Gasing-masing kelompok mempresentasikan hasil diskusi mereka } \\
\text { secara bergantian } \\
\text { berdiskusi. }\end{array}$ & \\
\hline $\begin{array}{l}\text { Penutup } \\
\text { - Guru bersama siswa menyimpulkan referensi tentang penyajian karya } \\
\text { musik } \\
\text { - Guru bersama siswa menyimpulkan konsep penyajian karya } \\
\text { musikseni musikyang ada dan berkembang } \\
\text { - Guru bersama siswa menyimpulkan jenisjenis penyajian karya musik } \\
\text { - Guru memberikan tugas kepada siswa untuk mempelajari media dan } \\
\text { teknik penyajian karya musik }\end{array}$ & 15 menit \\
\hline
\end{tabular}

\section{Pertemuan Kedua:}

\begin{tabular}{|l|c|}
\hline \multicolumn{1}{|c|}{ Rincian Kegiatan } & Waktu \\
\hline Pendahuluan/Kegiatan Awal & \\
- Merefleksi hasil pembelajaran pada pertemuan sebelumnya & \\
- Menagih analisis dan identifikasi media dan teknik membuat & 10 menit \\
- Menyajian karya musik & \\
- Menyampaikan tujuan pembelajaran & \\
\hline
\end{tabular}




\begin{tabular}{|c|c|}
\hline Rincian Kegiatan & Waktu \\
\hline $\begin{array}{l}\text { Kegiatan Inti } \\
\text { Mengamati } \\
\text { - Siswa saling membagi tugas dalam menganalisis dan } \\
\text { mengidentifikasi media dan teknik penyajian karya musik } \\
\text { - Guru mengamati dan menilai aktifitas siswa. } \\
\text { Menanya } \\
\text { - Siswa saling menanya tentang media dan teknik membuat } \\
\text { penyajian karya musik } \\
\text { - Guru mengamati, membimbing dan menilai aktifitas siswa. } \\
\text { Mengkomunikasikan } \\
\text { - Siswa secara berkelompok menganalisis dan mengidentifikasi } \\
\text { - } \text { media dan teknik membuat karya penyajian karya musik } \\
\text { - } \text { mengidentifikasi media dan teknik penyajian karya musik } \\
\text { mengidentifikasi media dan teknik penyajian karya musik }\end{array}$ & 70 menit \\
\hline $\begin{array}{l}\text { Penutup } \\
\text { - Bersama siswa menyimpulkan analisis dan identifikasi media dan } \\
\text { teknik penyajian karya musik } \\
\text { - Memberikan tugas untuk mengamati metode virtual drum dan } \\
\text { mempraktikkannya }\end{array}$ & 10 menit \\
\hline
\end{tabular}

\section{Pertemuan Ketiga:}

\begin{tabular}{|l|c|}
\hline \multicolumn{1}{|c|}{ Rincian Kegiatan } & Waktu \\
\hline Pendahuluan/Kegiatan Awal & \\
- Merefleksi hasil pembelajaran pada pertemuan sebelumnya tentang & \\
- Menagih tugas tentang metode virtual dan mempraktikkannya & 10 menit \\
- Menyampaikan tujuan pembelajaran & \\
- Menanyakan tentang praktik penyajian karya musik & \\
\hline Kegiatan Inti & \\
Mengamati & \\
- Siswa saling mengamati metode virtual drum dan mempraktikkan & 70 menit \\
- penyajian karya musik & \\
- $\quad$ Guru menyajian karya musik dengan metode pembelajaran virtual drum & \\
\hline
\end{tabular}




\begin{tabular}{|c|c|}
\hline Rincian Kegiatan & Waktu \\
\hline $\begin{array}{l}\text { Menanya } \\
\text { - Siswa saling menanya tentang penyajian karya musik dengan } \\
\text { metode virtual drum } \\
\text { - Guru mengamati, membimbing dan menilai aktifitas siswa. } \\
\text { Mengkomunikasikan } \\
\text { - Siswa secara kelompok menyiapkan hasil diskusi. } \\
\text { - Masing-masing kelompok diminta untuk mempresentasikan hasil } \\
\text { - diskusi. } \\
\text { - } \text { dengan mempraktikkan dan memberi contoh penyajian karya musik } \\
\text { - Siswa mempraktikkan penyajian karya musik dengan metode } \\
\text { virtual drum } \\
\text { Guru menilai pengetahuan dan sikap siswa dalam kerja kelompok } \\
\text { dan presentasi serta membimbing diskusi mereka. }\end{array}$ & \\
\hline $\begin{array}{l}\text { Penutup } \\
\text { - Bersama siswa menyimpulkan tentang penyajian karya musik dengan } \\
\text { metode virtual drum } \\
\text { - Memberikan tugas untuk mengapresiasi penyajian karya musik }\end{array}$ & 10 menit \\
\hline
\end{tabular}

G. Penilaian

1. Jenis/teknis penilaian

Penilaian dilakukan melalui penilaian proses dan penilaian hasil. Penilaian proses dilakukan melalui observasi kerja kelompok dan kerja individu, presentasi, dan laporan tertulis. Sedangkan penilaian hasil dilakukan melalui aktifitas kegiatan menganalisis bahan, media dan teknik dalam penyajian karya musik

2. Bentuk Instrumen dan Instrumen

Instrumen kinerja presentasi menggunakan lembar pengamatan kinerja presentasi dengan fokus penilaian pada: komunikasi, sistematikan penyajian, wawasan, keberanian, antusias dan penampilan.

Instrumen penilaian praktek dengan menggunakan rubrik penilaian praktek dengan fokus utama pada kegiatan langkah - langkah penyajian karya musik dengan metode virtual drum, persiapan dan pelaksanaan penyajian karya musik denagn metode virtual drum.

Instrumen observasi penilaian sikap kerja kelompok menggunakan lembar pengamatan dalam hal sikap kerjasama, bertanggung jawab, toleran, dan disiplin.

Instrumen observasi penilaian sikap kerja individu menggunakan lembar pengamatan sikap santun, jujur, cinta damai dalam mengapresiai seni dan pembuatnya. 
Instrumen observasi penilaian sikap kinerja presentasi menggunakan lembar pengamatan sikap responsif dan pro-aktif, peduli terhadap lingkungan dan sesama, menghargai karya seni dan pembuatnya.

\section{Pedoman penskoran \\ Pedoman penskoran terlampir.}

\section{H. Sumber/Referensi}

- Buku Teks Pelajaran Seni Budaya Kelas X SMA

- Informasi melalui internet

- Informasi melalui media cetak

- penyajian karya musik

Mengetahui Kepala

Moga, Juli 2016

Budaya

Guru Mata Pelajaran Seni

SMA Negeri 1 Moga

Dra. Titik Istiqomah, M.Pd

Erwanto, S.Pd

NIP. 196803041993022001

NIP. 197904282014061002

Catatan Kepala Sekolah : 
SUSUNAN ORGANISASI

SMA NEGRRI 1 MOGA

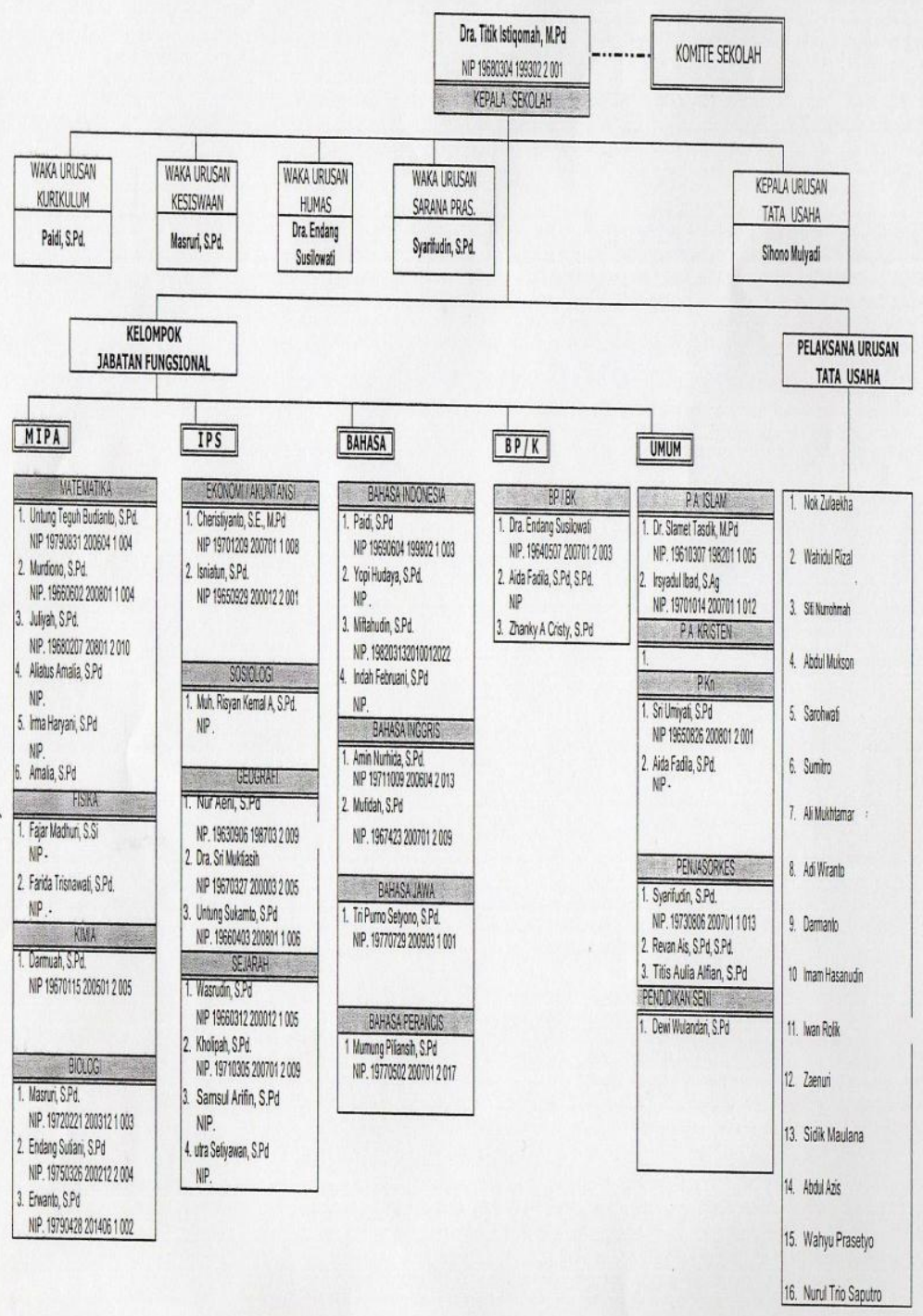


DAFTAR HADIR SISWA DALAM KEGIATAN PEMBELAJARAN SMA NEGERI 1 MOGA

TAHUN PELAJARAN 2016 / 2017

Kela : X BAHASA NAMA

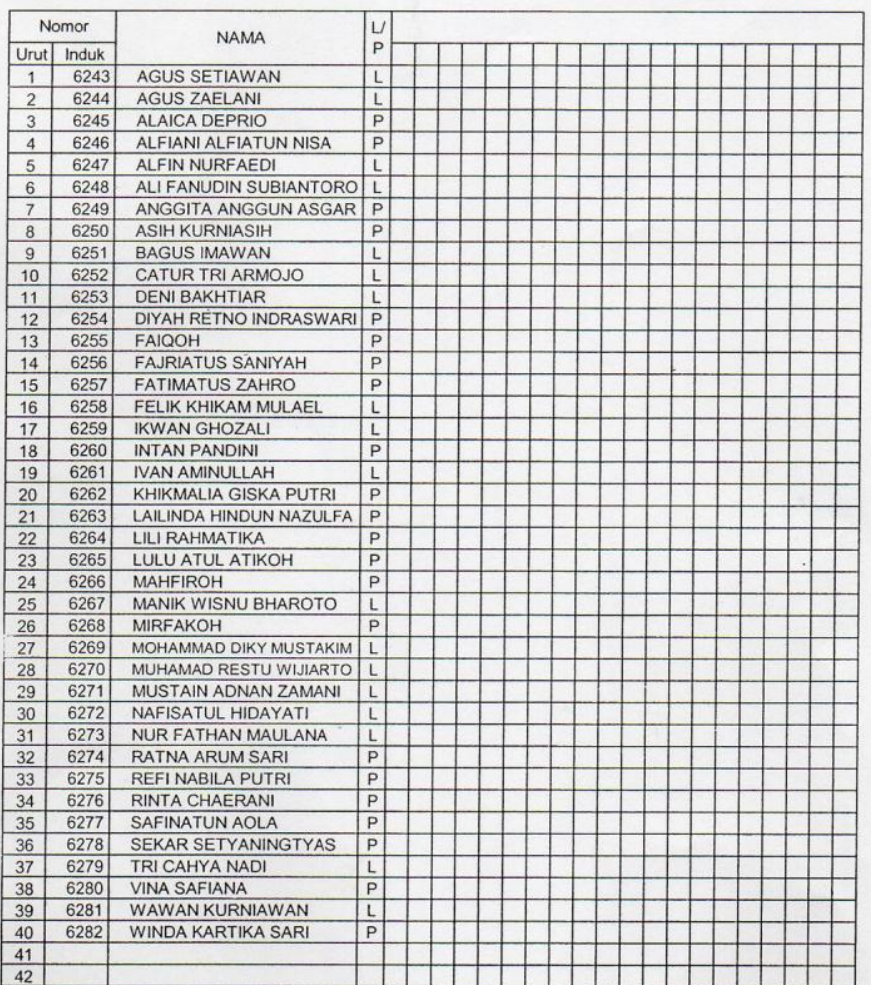
Moga,
Guru Mata Pelajaran
$L \quad=18$
$P \quad=22$
Mengetahui;
Kepala Sekolah,
$\mathrm{JML}=40$
Kepala Sekolah,
Dra. Titik Istiqomah, M.Pd.

NIP. 196803041993022001
Kelas XBAHASA

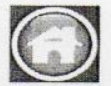




\begin{tabular}{|c|c|c|c|c|c|c|}
\hline No. & Nama & NIP & $L / P$ & Tempat, Tgl. Lahir & Jurusan & Mata Pelajaran \\
\hline 1 & Dra. Titik Istiqomah, M.Pd & 196803041993022001 & $P$ & Madiun, 4 Maret 1968 & Bhs. Inggris & Kepala Sekolah \\
\hline 2 & Dr. Slamet Tasdik, M.Pd. & 196103071982011005 & L & Brebes, 7 Maret 1961 & PAI & PAI \\
\hline 3 & Nur Aeni, S.Pd. & 196309061987032009 & $\mathrm{P}$ & Pemalang, 6 September 1963 & Geografi & Geografi \\
\hline 4 & Paidi, S.Pd. & 196906041998021003 & L & Klaten, 4 Juni 1969 & Bhs. Indonesia & Bhs. Indonesia \\
\hline 5 & Dra. Sri Muktiasih & 196703272000032005 & $\mathrm{P}$ & Pemalang, 27 Maret 1967 & Geografi & Geografi \\
\hline 6 & Wasrudin, S.Pd. & 196603122000121005 & L & Tegal, 12 Maret 1966 & Sejarah & Sejarah \\
\hline 7 & Isniatun, S.Pd. & 196509292000122001 & $\mathrm{P}$ & Pemalang, 29 September 1965 & Ekonomi & Ekonomi \\
\hline 8 & Endang Sutiani, S.Pd. & 197503252002122004 & $P$ & Kutoarjo, 25 Maret 1975 & Biologi & Biologi \\
\hline 9 & Darmuah, S.Pd. & 196701152005012005 & P & Pemalang, 15 januari 1967 & Kimia & Kimia \\
\hline 10 & Amin Nurhida, S.Pd. & 197110092006042013 & $\mathrm{P}$ & Trenggalek, 9 Oktober 1971 & Bhs. Inggris & Bhs. Inggris \\
\hline 11 & Masruri, S.Pd. & 197202212003121003 & L & Pemalang, 21 Februari 1972 & Biologi & Biologi \\
\hline 12 & Untung Teguh Budianto, S.Pd. & 197908312006041004 & L & Pemalang, 31 Agustus 1979 & Matematika & Matematika \\
\hline 13 & Dra. Endang Susilowati & 196405072007012003 & $\mathrm{P}$ & Tegal, 7 Mei 1964 & BK & BK \\
\hline 14 & Mufidah, S.Pd. & 196704232007012009 & $P$ & Pemalang, 23 April 1967 & Bhs. Inggris & Bhs. Inggris \\
\hline 15 & Irsyadul lbad, S.Ag. & 197010142007011012 & L & Pemalang, 154 Oktober 1970 & PAI & PAI \\
\hline 16 & Kholipah, S.Pd. & 197103052007012009 & $\mathrm{P}$ & Pemalang, 5 Maret 1971 & Sejarah & Sejarah \\
\hline 17 & Syarifudin, S.Pd. & 197308062007011013 & L & Pemalang, 6 Agustus 1973 & PJOK & PJOK \\
\hline 18 & Mumung Piliansih, S.Pd. & 197705022007012017 & $\mathbf{P}$ & Pemalang, 2 Mei 1977 & Bhs.Perancis & Bhs.Perancis \\
\hline 19 & Cheristiyanto, S.E.M.Pd & 197012092007011008 & L & Klaten, 9 Desember 1970 & Ekonomi & Ekonomi \\
\hline 20 & Sri Umiyati, S.Pd. & 196508262008012001 & P & Pemalang, 26 Agustus 1965 & PPKn & PPKn \\
\hline 21 & Untung Sukamto, S.Pd. & 196604032008011006 & L & Tegal, 3 April 1966 & Geografi & Geografi \\
\hline 22 & Murdiono, S.Pd. & 196606022008011004 & L & Makasar, 2 Juni 1966 & Matematika & Matematika \\
\hline 23 & Juliyah, S.Pd. & 196802072008012010 & $\mathrm{P}$ & Pemalang, 7 Februari 1968 & Matematika & Matematika \\
\hline 24 & Tri Purno Setyono, S.Pd. & 197707292009031001 & L & Boyolali, 29 Juli 1977 & Bhs. Jawa & Bhs. Jawa \\
\hline 25 & Yuli Arisandi, S.Kom & 197707182010011011 & L & Pemalang, 18 Juli 1977 & TIK & TIK \\
\hline 26 & Enwanto, S.Pd. & 197904282014061002 & L & Pemalang, 28 April 1979 & Biologi & Biologi \\
\hline 27 & Yopi Hudaya, S.Pd. & - & L & Pemalang, 1 Juni 1981 & Bhs. Indonesia & Bhs. Indonesia \\
\hline 28 & Miftahudin, S.Pd. & - & $\mathrm{L}$ & Pemalang, 18 Juni 1987 & Bhs.Indonesia & Bhs.Indonesia \\
\hline 29 & Revan Ais, S.Pd. & - & L & Pemalang, 27 Juni 1988 & PJOK & PJOK \\
\hline 30 & Fajar Madhuri, S.Pd & - & L & Pemalang, 17 Desember 1983 & Fisika & Fisika \\
\hline 31 & Farida Trisnawati, S.Pd & - & P & Pemalang, 6 September 1989 & Fisika & Fisika \\
\hline 32 & IIma Haryani, S.Pd & 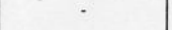 & P & Pemalang, 23 Januari 1991 & Matematika & Matematika \\
\hline 33 & Aliyatus Amalia, S.Pd & - & $P$ & Pemalang, 14 Mei 1988 & Matematika & Matematika \\
\hline 34 & Amalia,S.Pd & - & $\mathrm{P}$ & Pemalang, 19 Mei 1990 & Matematika & Matematika \\
\hline 35 & Zhanky A. Cristy, S. & - & L & Pemalang, 4 Maret 1989 & BK & BK \\
\hline 36 & Aida Fadila, S.Pd & - & $P$ & Pemalang, 9 April 1989 & BK & BK \\
\hline 37 & Sulkhan Affitudin, S.Pd & - & $\mathrm{L}$ & Pemalang, 11 Mei 1989 & Bhs. Jawa & Bhs. Jawa \\
\hline 38 & Dewi Wulandari, S.Pd & - & $\mathrm{P}$ & Pemalang, 16 April 1990 & Bhs. Perancis & Bhs. Perancis \\
\hline 39 & Indah Februani, S.Pd & - & L & Pemalang, 19 Februari 1989 & Bhs. Indonesia & Bhs. Indonesia \\
\hline 40 & TTiss Aulia Alfian, S.Pd & - & $\mathrm{P}$ & Pemalang, 12 Mei 1986 & PJOK & PJOK \\
\hline $\begin{array}{l}41 \\
42\end{array}$ & $\begin{array}{l}\text { Muhammad Risyan K.A, S.Pd } \\
\text { Samsul Arifin, S.Pd }\end{array}$ & : & $\begin{array}{l}\mathrm{L} \\
\mathrm{L}\end{array}$ & $\begin{array}{l}\text { Purworejo, } 26 \text { Januari } 1990 \\
\text { Pemalang, } 17 \text { April } 1990\end{array}$ & \begin{tabular}{|l} 
Sosiologi \\
Sejarah
\end{tabular} & $\begin{array}{l}\text { Sosiologi } \\
\text { Sejarah }\end{array}$ \\
\hline 43 & Andika Putra Setiawan, S.Pd & . & & Merauke, 21 Nopember 1991 & Sejarah & Sejarah \\
\hline
\end{tabular}

4. Tenaga Administrasi
\begin{tabular}{|r|l|c|c|l|c|}
\hline No. & \multicolumn{1}{|c|}{ Na ma } & NIP & L/P & \multicolumn{1}{|c|}{ Tempat, Tgl. Lahir } & Keterangan \\
\hline 1 & Sihono Mulyadi & 195812271986021003 & L & Sragen, 27 Desember 1958 & Ka TU \\
\hline 2 & Nok Zulaekha & 198108082010012007 & P & Pemalang, 8 Agustus 1981 & Staf TU \\
\hline 3 & Wahidul Rizal & 197202282008011004 & L & Pemalang, 28 Februari 1972 & Staf TU \\
\hline 4 & Siti Nurrohmah & 19643302008012002 & P & Pemalang, 30 Maret 1964 & Staf TU \\
\hline 5 & Abdul Mukson & 197209062009011009 & L & Pekalongan, 6 September 1972 & Staf TU \\
\hline 6 & Sarohwati & 198109152014062002 & P & Pemalang, 15 September 1981 & Staf TU \\
\hline 7 & Sumitro & 197802272014062005 & L & Pemalang, 27 Februari 1978 & Staf TU \\
\hline 8 & Ali Mukhtamar & 198202012014061003 & L & Pemalang, 1 Februari 1982 & Staf TU \\
\hline 9 & Adi Wiranto & - & L & Pemalang, 15 Januari 1977 & Staf TU \\
\hline 10 & Darmanto & - & L & Pemalang, 8 Mei 1983 & Staf TU \\
\hline 11 & Iwan Rolik & - & L & Pemalang, 5 Januari 1974 & K7 \\
\hline 12 & Imam Hasanudin & - & L & Pemalang, 10 Oktober 1984 & K7 \\
\hline 13 & Zaenuri & - & L & Pemalang, 28 Februari 1989 & Penjaga malam \\
\hline 14 & Sidik Maulana & - & L & Pemalang, 10 MEl 1989 & Satpam \\
\hline 15 & Abdul Azis & - & L & Pemalang, 12 Juli 1991 & Penjaga malam \\
16 & Wahyu Prasetyo & L & Peemalang, 19 e 1992 & K7 \\
17 & Nurul Trio Saputro & - & L & Pemalang, 4 Mei 1988 & Staf TU \\
\hline
\end{tabular}


